University of Redlands

\title{
Assessment of Climate Change Scenarios on the Yukon River Basin
}

\author{
A Major Individual Project submitted in partial satisfaction of the requirements \\ for the degree of Master of Science in Geographic Information Systems \\ by \\ John Ngwembo Yembu \\ Mark Kumler, Ph.D., Committee Chair \\ Ruijin Ma, Ph.D.
}

December 2012 
Assessment of Climate Change Scenarios on the Yukon River Basin

Copyright (C) 2012

by

John Ngwembo Yembu 
The report of John Ngwembo Yembu is approved.

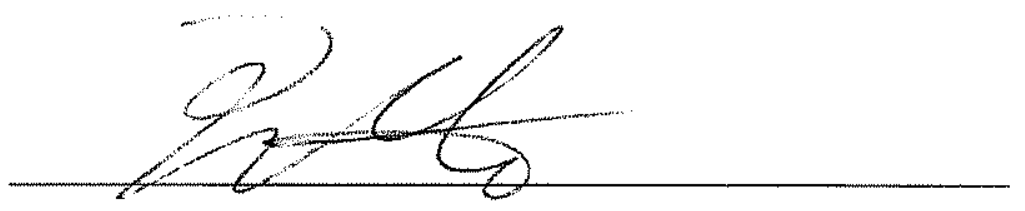

Ruijin Ma, Ph.D.

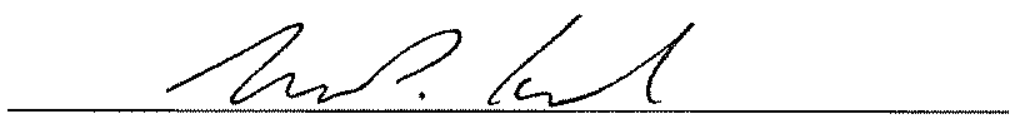

Mark Kumler, Ph.D., Committee Chair

December 2012 



\section{Acknowledgements}

My gratitude goes to the Almighty God who granted me wisdom and health throughout this program. Much appreciation to my advisor Prof. Mark Kumler for all his positive contributions, and to the director of the MS GIS Program, Prof. Douglas Flewelling for providing the enabling environment for the program to go on smoothly.

My appreciation also goes to the staff of the MS GIS Program, Prof Ruijin Ma my second reader, Prof. Fang Ren, Lynn Flewelling the editor, and finally to our dear mother, life wire and program coordinator Debra Riley. Thanks to all the members of Cohort 21 especially Clifford Okembo, Oludamilola Eyelade, Melodi King and Andrew Molis for all your support.

I highly appreciate the incessant support, prayers, and inspiration of my wife, Mrs. Yembu Jackline, my children; Lynna, Jude -Ryan, Emmanuel and Justin- Bryan. I sincerely appreciate my mother in-law Mrs. Ngang Mary for always being there for us. My entire family is recognized for all their contribution and understanding, especially my mum, grand mum, brothers and sisters. I appreciate the moral support and encouragement of Che Senge, the Effiong's family, Terence Ndifuanja, Ralph Enow, Paul, Oyerinde Mama Angelica, Papa and Mama Agbor.

I appreciate the support of the National Center for Atmospheric Research for providing me with the opportunity to be part of enhancing diversity in climate change workshop. Jennifer Boehnert and Kelvin Sampson, a million thanks for making me a great person in climate change issues, all your constant feedback led to the success of this project. 



\begin{abstract}
Assessment of Climate Change Scenarios on the Yukon River Basin

By

John Ngwembo Yembu

There are indications that the climate is going to experience drastic change in the future, as it has occurred in the past and is currently happening now. Climate simulations have shown some potential hydrologic effects of climate change in the Yukon River Basin due to changes in temperature and precipitation. The Yukon River Inter-Tribal Watershed Council currently does not utilize spatial software to manage, analyze, or produce maps of climate change scenarios in the Yukon River basin. It is important to create a geodatabase, determine differences in climate change scenarios, and calculate peak discharge rates in the different regions using geospatial techniques. Climate modeling is one of the best tools available to determine the trends in future climate. In this project, the temperature and precipitation differences for the 20th century (1980-1999) and midcentury (2040-2059), were determined with data from the National Center for Atmospheric Research (NCAR), Community Climate System Model (CCSM), indicating a future increase in temperature and precipitation. The U.S. Geological Survey regression equations, basin characteristics, and pythonWin were used to create a python script and tool to calculate peak discharge rates. The methods used in this project allow it to be easily adapted for future projects in the Yukon River Basin.
\end{abstract}





\section{Table of Contents}

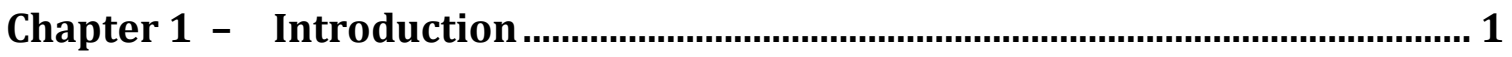

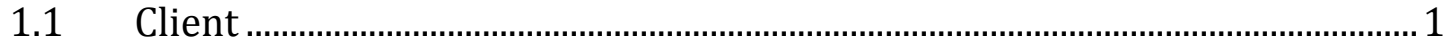

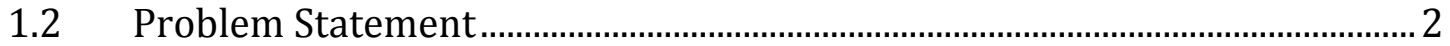

1.3 Proposed Solution.................................................................................................. 2

1.3.1 Goals and Objectives ………………………………………………………..

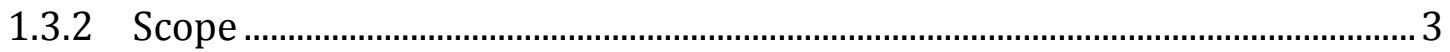

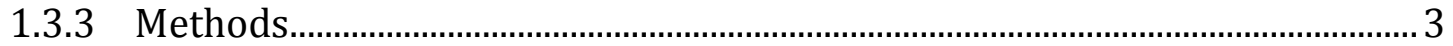

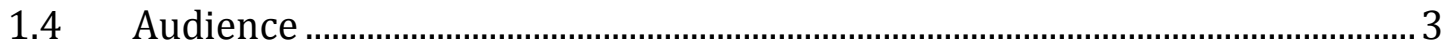

1.5 Overview of the Rest of this Report ................................................................... 3

Chapter 2 - Background and Literature Review.................................................... 5

$2.1 \quad$ Climate Change Prediction ...............................................................................

2.2 Science and Climate Change.................................................................................

2.3 Modeling Climate Change..................................................................................... 6

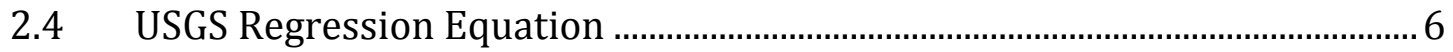

2.5 Community Climate Simulation System Models ............................................... 6

2.6 Climate Change and Water Resources ................................................................

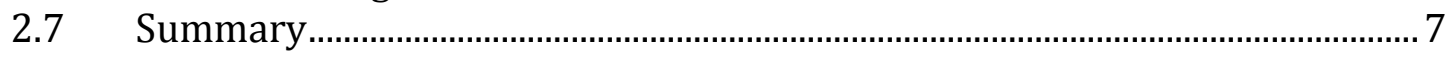

Chapter 3 - Systems Analysis and Design ……................................................... 9

$3.1 \quad$ Problem Statement..........................................................................................

3.2 Requirements Analysis ................................................................................. 9

3.2.1 Functional Requirements.............................................................................. 9

3.2.2 Non-functional Requirements...................................................................... 10

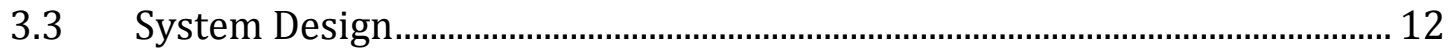

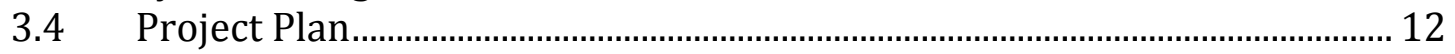

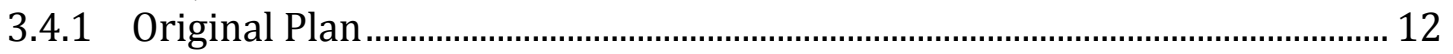

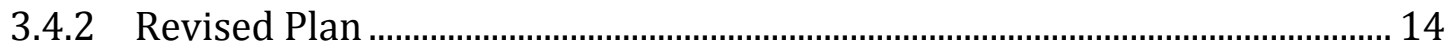

Chapter 4 - Database Design ..........................................................................15

4.1 Conceptual Data Model .................................................................................. 15

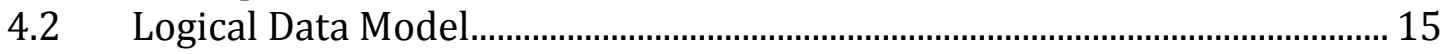

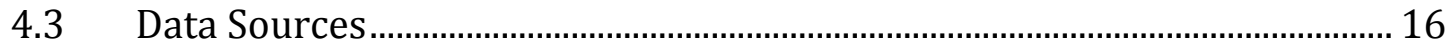

4.4 Data Scrubbing and Loading .............................................................................. 18

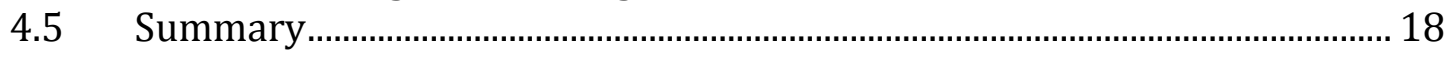

Chapter 5 - Implementation .........................................................................19

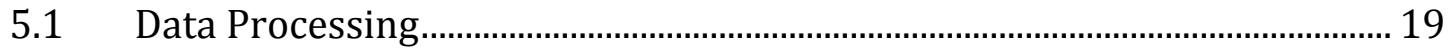

5.1.1 Data Download and Projection ......................................................................... 19

5.1.2 Climate Data Conversion .............................................................................. 22

5.1.3 Temperature Range 20th Century and Mid-Century Scenarios................... 24

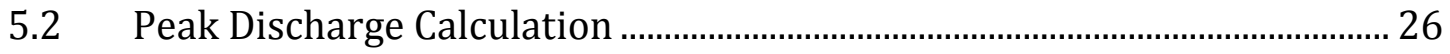

5.2.1 USGS Regression Equations and Basin Characteristics ................................ 26

5.2.2 USGS Regression Equation and Basin Characteristics for Region ............... 27

5.2.3 Python Script Tools for Two Time Period ........................................................ 27 


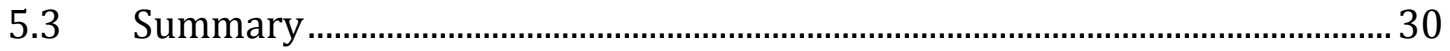

Chapter 6 - Results and Analysis......................................................................31

6.1 Climate Change Scenarios Results ................................................................ 31

6.2 Peak Discharge Calculation............................................................................. 31

6.2.1 Basin Characteristics Output for USGS Regions............................................... 31

6.2.2 Peak discharge for the Two Time Periods .......................................................32

6.3 Changes in Peak Discharge between the Two Scenarios ..................................36

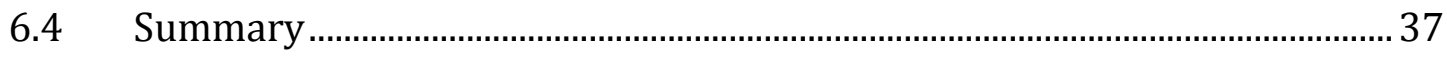

Chapter 7 - Conclusions and Future Work ……....................................................39

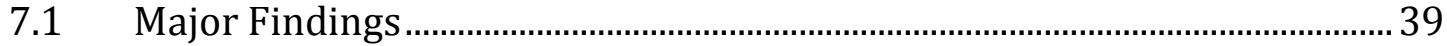

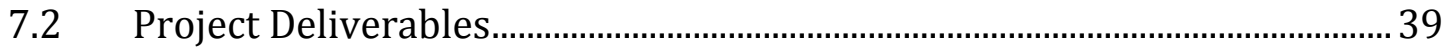

7.3 Future Works and Suggestions ……………………………………………... 39

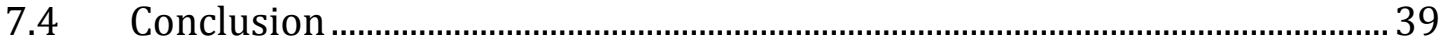

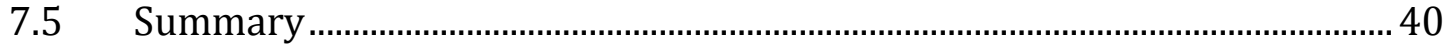

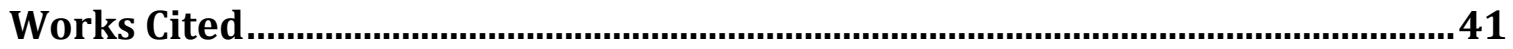

Appendix A. Climate Change Maps and Charts..............................................45

Appendix B: Peak Discharge ...............................................................................48

Appendix C: Forest Data preparation ……...........................................................50

Appendix D: Instruction Manual...........................................................................51 


\section{Table of Figures}

Figure 1-1: Location of the Yukon River Basin in Canada and Alaska .................... 1

Figure 3-1: System Architecture ....................................................................... 12

Figure 4-1: The Conceptual Data Model .................................................................. 15

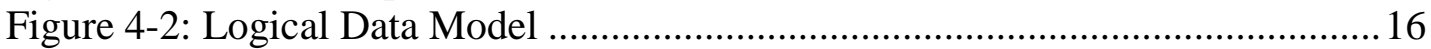

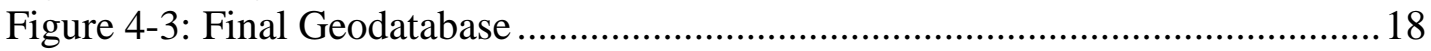

Figure 5-1: Project Implementation Work Flow.................................................... 19

Figure 5-2: Mean January Temperature for the 20th Century .................................20

Figure 5-3: Mean January Temperature for the Mid-Century ................................220

Figure 5-4: Mean Annual Precipitation for the 20th Century .................................. 21

Figure 5-5: Mean Annual Precipitation for the Mid-Century .....................................21

Figure 5-6: Join Tables and Field Calculator on Temperature ................................22

Figure 5-7: Join Tables and Field Calculator on Precipitation ...............................2 23

Figure 5-8: Inverse Distance Weighted (IDW) for Temperature Difference ............ 23

Figure 5-9: Clipped Temperature Difference .................................................... 24

Figure 5-10: Calculating the Temperature Difference Dataset ..................................24

Figure 5-11: Calculating the Temperature Change Dataset....................................25

Figure 5-12: Scanned Yukon River Basin regions from the USGS Alaska report ....25

Figure 5-13: Zonal Statistics tool used to calculate Temperature differences ...........26

Figure 5-14: Temperature Zonal Statistics as Table tool ..........................................26

Figure 5-15: Python Script for Region 3 ....................................................... 28

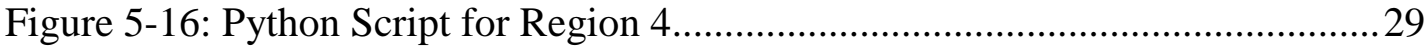

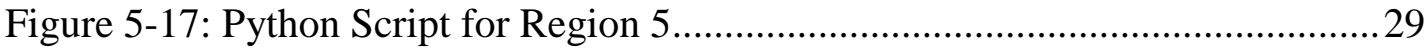

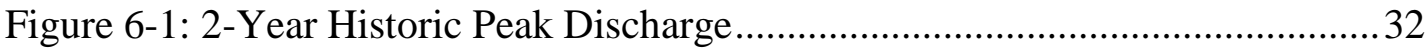

Figure 6-2: 25-Year Historic Peak Discharge............................................................ 33

Figure 6-3: 50-Year Historic Peak Discharge ........................................................ 33

Figure 6-4: Historic Peak Discharge Rates ............................................................... 34

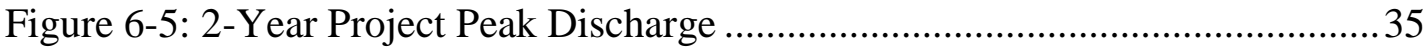

Figure 6-6: 25-Year Project Peak Discharge .......................................................... 35

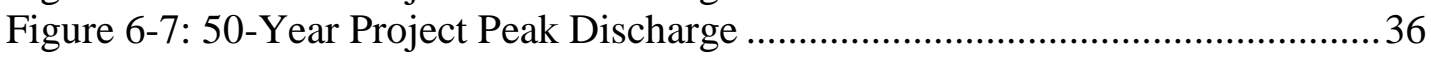

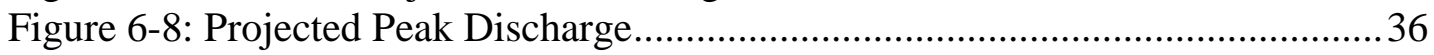





\section{List of Tables}

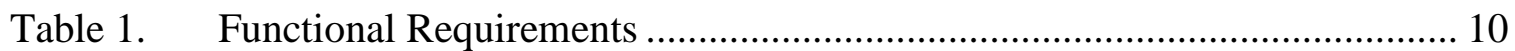

Table 2. Nonfunctional Requirements for the System ....................................... 11

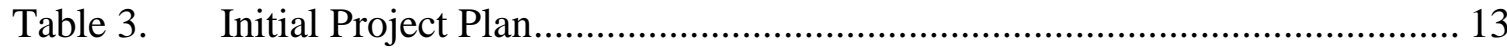

Table 4. YRITWC Climate Change and Discharge MIDL ........................................ 16

Table 5. Minimum Mean Temperature for the 20th and Mid-Century...................... 31

Table 6. Region Characteristics that Remain Constant between Scenarios............... 31

Table 7. Basin Characteristics for 20th and Mid-Century Periods ........................... 32

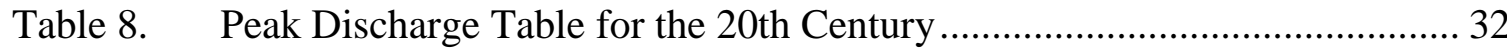

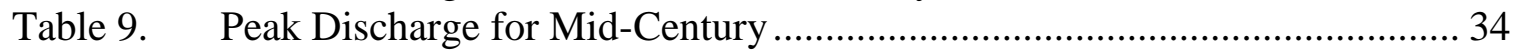

Table 10. Change in Peak Discharge between the Two Time Periods ......................... 37

Table 11. Change in Peak Discharge between the Two Time Periods (\%) .................. 37 



\section{List of Acronyms and Definitions}

$\begin{array}{ll}\text { CCSM } & \text { Climate Community System Model } \\ \text { CFS } & \text { Cubic Feet per Second } \\ \text { GCM } & \text { General Circulation Model } \\ \text { GCM } & \text { Global Climate Model } \\ \text { GIS } & \text { Geographic Information Systems } \\ \text { GCM } & \text { Global Coupled Model } \\ \text { IDW } & \text { Inverse Distance Weighted interpolation } \\ \text { IPCC } & \text { Intergovernmental Panel on Climate Change } \\ \text { IPD } & \text { Information Product Definition } \\ \text { MIDL } & \text { Master Input Data List } \\ \text { NCAR } & \text { National Center for Atmospheric Research } \\ \text { NAD } & \text { North America Datum } \\ \text { Q2 } & \text { Two-Year Returns Period } \\ \text { Q25 } & \text { Twenty Five-Year Returns Period } \\ \text { Q50 } & \text { Fifty - Year Returns Period } \\ \text { UML } & \text { Unified Modeling Language } \\ \text { USGS } & \text { United States Geological Survey } \\ \text { UTM } & \text { Universal Transverse Mercator } \\ \text { YRB } & \text { Yukon River Basin } \\ \text { YRITWC } & \text { Yukon River Inter-Tribal Watershed Council }\end{array}$





\section{Chapter 1 - Introduction}

Climate simulations have shown some potential hydrologic effects of climate change on the Yukon River Basin (YRB) in forms of changes in temperature and precipitation. Projected increases in temperature will likely lead to a rise in runoff which might be balanced by an increase in evaporation (Hay \& Gregory, 2010). There had been great attention in climate change since early times revealing that climate change is not restricted only to the past but it is taking place on time scales with impact on human activities (Neelin, 2011).

The third longest river in North America, flowing through northern British Columbia and Alaska is the Yukon River; it has a length of 3185 kilometers and a watershed drainage area of 840,000 square kilometers (Services PR, 1997).

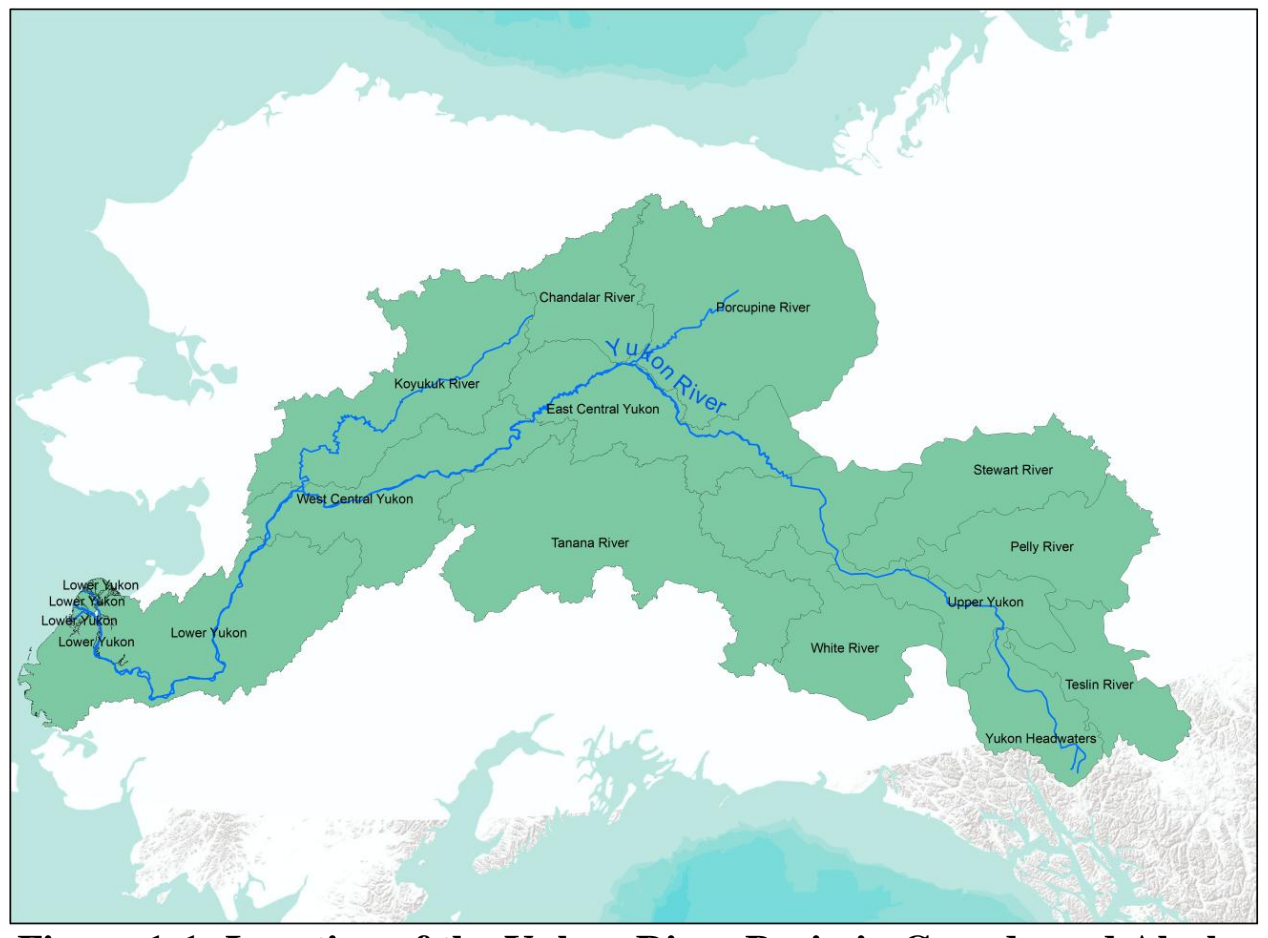

Figure 1-1: Location of the Yukon River Basin in Canada and Alaska

\subsection{Client}

Ryan Toohey was the client for this project. In that capacity, he was able to provide direct links to data sources, as well as data collected by the Yukon River Inter-Tribal Watershed Council (YRITWC). He specified requirements for a mapping application to analyze and visualize the climate data. He was also there to direct the research, clarify methodologies, and answer questions about the study area. He reviewed progress and suggested changes or corrections to deliverables.

YRITWC is an indigenous grass roots organization and collaborative partner of the United States Geological Survey (USGS). It is an international organization with 501(c) 
(3) non-profit status in the United States and Societal Status in Canada. It is a coalition of sovereign tribal and First Nation governments, founded in 1997 by a group of 56 chiefs and elders who gathered in Galena, Alaska, to discuss their concerns about increased cancer and other health problems in human communities and game species within the Yukon River watershed. The long-term vision for the organization was articulated by the tribal leaders at the historic 1997 summit that birthed the Watershed Council: to once again drink clean water directly from the Yukon River as their ancestors had for thousands of years (YRITWC, 2005).

\subsection{Problem Statement}

The YRITWC currently does not utilize spatial software to manage, analyze, and produce maps of climate change scenarios in the Yukon River basin. Their data are currently stored in different file formats in an external hard drive, not in a geodatabase. The client needed to know how to determine climate change differences which will enable visualizing of climate change in Yukon River Basin, and also how to calculate peak discharges in the different regions of the Yukon River Basin. Therefore, the client needs a complementary analysis to help provide answers on: What are the climate change scenarios on the Yukon River Basin using geospatial techniques? How can peak discharge be determined in the Yukon River Basin? What will be the changes in climate in the Yukon River Basin in the future?

\subsection{Proposed Solution}

Three solutions were proposed in this study. The first solution was to create a geodatabase to make sure that the client data are stored in a spatial environment to enable analysis. The second solution was to calculate the peak discharge for the Yukon River basin. This will help to determine the rate of runoff in the different regions of Yukon River Basin. To address the third need of the client, climate change differences were calculated for periods of 1980-1999 and the 2040-2059 in ArcGIS with data from the National Center for Atmospheric Research (NCAR) Climate Community System Model (CCSM), designed to predict future climate forecast as well as provide further analysis on the open space climate change scenarios for the Yukon River Inter-Tribal Watershed Council.

The designed solution was to use Geographic Information Systems (GIS) to determine climate change differences for the $20^{\text {th }}$ century (1980-1999) and mid-century (2040-2059), and to create a tool to calculate peak discharge rates. With this tool, the client was able to calculate peak discharge for the regions in the Yukon River Basin. The tool should be reusable in the future to calculate peak discharges on the Yukon River Basin for the mid-century (2040-2059) and end of century (2080-2099), with changes in basin characteristics. The code was written in pythonWin and a script tool was created from it in ArcGIS.

\subsubsection{Goals and Objectives}

The main goal for this project was to determine the differences between climate change scenarios in the Yukon River Basin. 
The three main objectives were:

- To determine peak discharge in Yukon River Basin;

- To determine changes in peak discharge over time;

- To determine differences between climate change scenarios.

\subsubsection{Scope}

To be able to attain the client's goals, three major GIS components were developed and included in the project documentation, namely a GIS geodatabase, peak discharges, and a climate change difference. The GIS geodatabase was configured to store, organize, modify, and extract spatial data relevant to the Yukon River Basin and climate change analysis. The peak discharges were calculated using the USGS regression equations. The third GIS component, a climate change difference were calculated for 1980-1999 and 2040-2059. The project is limited to the Yukon River Basin.

\subsubsection{Methods}

To produce the major GIS components, several steps were involved. Geodatabase design involved extracting the main feature classes from the client's master data and data from NCAR, and normalizing the attribute tables. In addition, data manipulation and data conversion were performed from the feature classes to layer files. The user needs and requirements were considered in creating the geodatabase and calculating the peak discharge rates. Finally, the climate change anomaly was calculated in ArcGIS environment, using the NCAR Climate Community System Model (CCSM) to determine climate change difference for present, the 20th Century and the Mid-Century scenarios.

\subsection{Audience}

This document will be used by the 70 Alaska Native Tribes and Yukon First Nations that the YRITWC represents. It will be of interest to those who frequently work with climate data to assess climate change anomalies and prediction of future changes in climate. The science department manager for the YRITWC will use this document frequently to calculate peak discharge rates on the Yukon River Basin.

\subsection{Overview of the Rest of this Report}

The goal was to educate readers on the possibilities of GIS applications in climate change scenarios and discuss the methods applied. Chapter 2 will provide the background and literature review on climate change scenarios on the Yukon River Basin and climate change predictions. Chapters 3 and 4 will examine the system and database design for the GIS applications. These chapters will present information on the user needs and information products, as well as the data development methods used. Chapter 5 will deal with the implementation strategy applied. Chapter 6 will look at the results and analysis, and Chapter 7 will present conclusions. 



\section{Chapter 2 - Background and Literature Review}

In order to effectively predict climate change at global, regional, and local levels, precise methods are imperative that will clearly assess its impacts by developing appropriate adaptation and mitigation guidelines (Giorgi, 2005). A lot has been done in handling the challenges of climate change by scientists and economists taking into account risks, costs, and also how future changes will look like (Nordhaus, 1994). Knox (2012) states "... one sees climate change as an urgent problem that threatens our planet; one does not. I want our president to place scientific evidence and risk management above electoral politics." (Bloomberg, 2012) referenced Knox and added "... our climate is changing, and while the increase in extreme weather we have experienced in New York and around the world may or may not be the result of it, the risk that it might be-given this week's devastationshould compel all elected leaders to take immediate action."

\subsection{Climate Change Prediction}

Climate change will have a significant effect on water resources in many parts of the world, and in the future may lead to extreme weather conditions. Population increase has been identified as a significant barrier to sustainable use of water resources due to constant demand, which is posing challenges to climate in the present century. This effect is going to be more prominent in the developing countries which are always prone to water shortages (Jones J. , 1999). Determining the state of the atmosphere is essential in predicting how specific weather patterns evolve at different times of the day. There are many uncertainties and shortcomings, especially when it comes to predicting current climate. It will be a good idea that the end users should be aware of what is happening (Giorgi, 2005).

Climate change prediction requires effort to predict anthropogenic impacts on the environment, as well as natural phenomena that affect daily activities. A lot still has to be done at the level of mitigation strategies, government policy, international protocols, and conventions when making decisions in predicting climate change caused by human impact. The human dimension of climate science focuses on how the public interprets predictions, natural climate variations, and the usefulness of the information to countries or interest groups (Neelin, 2011).

\subsection{Science and Climate Change}

There are indications that the climate is going to experience drastic change in the future, as it has occurred in the past and is currently happening. Changes in environmental quality and climate will exact enormous effects on the quality of life especially with the rise in urbanization, industrialization, and pollution (Dangermond \& Artz, 2010).

Considering anticipated changes in global climate and ecology, there are great indications that the effects will be very visible on human activities in the nearest future. Therefore, it is important to independently examine the consequences brought by anthropogenic activities (Dale, 1997). There have been variations in winter precipitation in western North America from projected climate warming, resulting from slight changes 
in snow conditions which are influenced by changes in climate at macro and micro scales (Lapp, Bryne, Townshend, \& Kienzle, 2005).

Studies have been carried out and indicated a steady rise of average surface temperatures, shifts in precipitation ranges, and other climatic happenings are the most significant means to confirmed changes in climate (The Intergovernmental Panel on Climate Change (IPCC, 2007). Lin, Hong, Wu, Wu, \& Verburg (2007) indicated that "...land use change can be characterized by the complex interaction of behavioral and structural factors associated with demand, technological capacity, and social relations, which in turn affect demand and environmental capacity, as well as the nature of the environment in question" (p.111).

\subsection{Modeling Climate Change}

It is advisable to use climate models to predict future trends in climate, even though they have a high degree of uncertainty. There are a lot of uncertainties to determining future emissions, as changes will probably happen in technological development before the end of this century. To predict future occurrences in climate, the IPCC developed a set of scenarios that indicate future emissions ranging from changes in demographics to technology. The range of possible future scenarios can provide us with the best understanding of how the future climate will look (Boehnert, 2012).

In order to acquire data for weather forecasting, computer models are used that have sufficient speed with automatic techniques for data input, quality control, interpolation, and mining data points in sparsely covered regions. It is not possible for a climate model to precisely reproduce every detail of the real climate. For example different runs of the General Circulation Model may produce different temperature and rainfall values. Due to the complexity of models, it is difficult to determine the difference in performance; therefore it is important to get a close and realistic climate change result with little adjustments to an understanding showing why the system behaves as it does (Edwards, 2010).

\subsection{USGS Regression Equation}

Different statistical methods have been established. Regression analysis conducted on basin climate, physical characteristics, and peak flows in conterminous basins of Canada and Alaska helped determine the magnitude of floods on stream sites (Jones \& Fahl, 1994).

Standardized statistical procedures have been used to collect data for surface water stations that provide information on peak stream flow magnitude estimates, for 2-, 5-, 10-, 25-, 50-, 100-, 200-, and 500-year recurrence intervals. The physical characteristics, climate, and statistics of the drainage basins are necessary to develop equations that determine the peak stream flows at sites where little or no data have been collected (Curran, Meyer, \& Tasker, 2003).

\subsection{Community Climate Simulation System Models}

In order to simulate climate scenarios, the community climate system model (CCSM) has four components, the atmosphere, ocean, sea ice, and land surface, is greatly utilized. It has been used by students, researchers, and scientists to study inter annual and decadal 
inconsistency in the simulation of past climate systems, and to estimate changes in future anthropogenic climate. There are three versions of the CCSM, with version three presented to the climate community through the National Center for Atmospheric Research (NCAR) on June 23, 2004. It is good at producing realistic simulations over a wide range of spatial resolutions, climate change, variability, and supporting simulations lasting several millennia (Collins, et al., 2005).

For studies involving the natural variability of the climate system and its response to changes, general circulation models are usually used. To include chemical and biogeochemical processes in the future, the climate system model version one was developed as a comprehensive model of the climate system. The modeling system is made freely available to the general community by NCAR (Boville \& Gent, 1998).

The second version of the CCSM was described as a 1000- control simulation of present climate accomplished without modifications of flux. Whenever the control simulation is above 150 years it provides or indicates small trends in the upper-ocean, sea ice, atmosphere, and land surfaces. Even though the deep ocean has meaningful and small trends, this cannot permit the control simulation to continue much further (Kiehl \& Gent, 2004).

Edwards (2010) argued that “... Simulation models are based on physical theory, even though after atmospheric physics became adequate to the task early in the twentieth century, computational friction prevented serious attempts to simulate weather or climate mathematically. Weather forecasters built numerical models to calculate the atmosphere's large scale motions and predict the weather. Climate scientists then used similar techniques to simulate the global climate for long periods. By changing the simulated forces and conditions, they also used models to predict how climate will change as human activity alters the composition of the atmosphere and other climate-related systems" (Edwards, 2010).

\subsection{Climate Change and Water Resources}

Watershed hydrology could be affected by vegetation types, soil properties, geology, terrain, climate, land use practices, and spatial patterns of interactions among these factors (Tomer \& Schilling, 2009). There are indications of future warmer climate from a baseline dataset of water quality which served as an important frame of reference to assess future changes on the Yukon River Basin (Schuster, Bryan, \& Nicole, 2010).

Hydrological models and GIS techniques are becoming more useful in determining rainfall and run off simulations and are able to predict floods, climate changes, and land use impacts on flooding. GIS techniques are more capable of determining hydrological parameters of terrain and digital elevation model (Bahremand $\&$ Smedt, 2008).

\subsection{Summary}

Climate change is the single largest environmental and humanitarian crisis of this century. Accurate climate change predictions are needed at the global and, more importantly, at regional and local scales. The United States Geological Survey has used 
regression equations to estimate the magnitude of flood on streams in Alaska. Coming up with appropriate methods to determine how changes in climate would affect Yukon River peak discharge would be of great interest to the Yukon River Inter-Tribal Watershed Council. 


\section{Chapter 3 - Systems Analysis and Design}

\subsection{Problem Statement}

The Yukon River Inter-Tribal Watershed Council currently does not utilize spatial software to manage, analyze, or produce maps of climate change scenarios on the Yukon River Basin. The client data are currently stored in different file formats in an external hard drive, rather than in a geodatabase. The client cannot determine difference in climate change to aid in visualizing climate change scenarios in the Yukon River Basin, and cannot determine the peak discharge rates in the different regions of the Yukon River Basin.

\subsection{Requirements Analysis}

The focus of this project was to create three major components: a geodatabase, peak discharge rates, and difference in climate change scenarios. The deliverables were created to allow the client or any other knowledgeable ArcGIS user to easily analyze, visualize, and edit data, calculate peak discharge rates, and predict climate change in the Yukon River Basin. The waterfall methodology was used in the original project plan, where requirements were gathered, reviewed, and implemented.

A requirements analysis was conducted to evaluate whether the proposed tool would meet the client's specific needs. It involved documenting use cases and information product descriptions, as well as creating a sample questionnaire. This was to identify and evaluate the functional and non-functional requirements of the project, which were specified by the client and incorporated into the project.

\subsubsection{Functional Requirements}

The functional requirements described the functions that the script tool had to do, specifically to calculate the peak discharges and to determine the differences between the two climate change scenarios. The client needed a geodatabase to store spatial data, determine differences between climate change scenarios, and predict peak discharges. This new information was presented in maps, charts and tabular format. The requirements for the tools are presented in Table 1. 
Table 1. Functional Requirements

\begin{tabular}{|l|l|}
\hline Requirement & Comments \\
\hline File geodatabase storage & Created by the researcher \\
\hline $\begin{array}{l}\text { Current and future climate scenarios for Yukon River } \\
\text { Basin }\end{array}$ & $\begin{array}{l}\text { Climate Anomaly calculated } \\
\text { in ArcGIS }\end{array}$ \\
\hline $\begin{array}{l}\text { Use two climate range years to determine current and } \\
\text { future climate change }\end{array}$ & $\begin{array}{l}\text { Choice of years: } 20^{\text {th }} \text { century } \\
\text { or historic climate } \\
\text { simulations }(1980-1999) \text { and } \\
\text { high A2 scenario }(2040- \\
\text { 2059) Mid-Century average }\end{array}$ \\
\hline Use existing climate data & NCAR CCSM \\
\hline Climate difference & Determined by the researcher \\
\hline Peak discharge rates & Calculated \\
\hline Ability to print the map display & When needed \\
\hline
\end{tabular}

The client wanted a tool that could be easily used by a knowledgeable Arc GIS user to calculate peak discharge rates. The tool was designed to be modifiable and repeatable so that a user could update the data and the differences in climate change scenarios as needed.

\subsubsection{Non-functional Requirements}

The primary non-functional requirement was that the tool would work with new model output. The climate parameters had to be updateable because information in the Yukon River Basin is always changing. It is also possible that the client will need to determine peak discharges in other geographic areas. To accommodate the updated information, the tool should be automated and easy to operate. Therefore, the tool needed to handle different basin characteristics to meet these non-functional requirements. In addition, a geodatabase was necessary for data storage and organization to assist in the calculations and data maintenance.

Non-functional requirements focus on how the tool will perform these tasks. These included the usability, technical, operational, transitional, and legislative requirements that were developed from the use cases are presents in Table 2. 
Table 2. Non-functional Requirements for the System

\begin{tabular}{|l|l|l|}
\hline \multicolumn{1}{|c|}{ Type } & \multicolumn{1}{|c|}{ Requirement } & \multicolumn{1}{c|}{ Description } \\
\hline \multirow{4}{*}{ Usability } & Easy to use & Simple design \\
\cline { 2 - 3 } & Effectiveness & $\begin{array}{l}\text { Users should be able to perform tasks } \\
\text { accurately }\end{array}$ \\
\cline { 2 - 3 } Technical & Efficiency & $\begin{array}{l}\text { Users should be able to complete the tasks } \\
\text { within a given time }\end{array}$ \\
\cline { 2 - 3 } & ArcGIS Desktop 10.0 & $\begin{array}{l}\text { The climate anomaly and python script } \\
\text { applications were created using ArcGIS } \\
\text { Desktop 10.0 }\end{array}$ \\
\hline \multirow{2}{*}{ Operational } & Data Storage & $\begin{array}{l}\text { File geodatabase storage for climate } \\
\text { difference, script and peak discharges }\end{array}$ \\
\hline \multirow{3}{*}{ Transitional } & Script tool & $\begin{array}{l}\text { Calculate peak discharges and display the } \\
\text { results }\end{array}$ \\
\cline { 2 - 3 } & Desting & $\begin{array}{l}\text { Data were projected to NAD_1927 } \\
\text { Alaska_Albers_Meters }\end{array}$ \\
\cline { 2 - 3 } & Demonstration & Peak discharge rates calculated and script run \\
\cline { 2 - 3 } & System Documentations & $\begin{array}{l}\text { Information on how to run the script tool } \\
\text { difference and script, metadata for the script } \\
\text { tool, an instruction manual, and a project } \\
\text { report }\end{array}$ \\
\hline \multirow{2}{*}{ Legislative } & Privacy Protection & $\begin{array}{l}\text { Removing owner names associated with } \\
\text { climate difference }\end{array}$ \\
\hline
\end{tabular}

Usability requirements focused on ease of use, effectiveness, and efficiency. There was the need for the geodatabase and script tool to efficiently generate the climate difference datasets, and peak discharge rates. It was also important to maximize user effectiveness in accomplishing these tasks.

Technical requirements focused on the layout and minimum software specifications. To be able to determine climate differences or create maps for display, the client needs ArcGIS Desktop 10.0. A geodatabase was necessary to organize and store the data, as well as to calculate climate differences and peak discharge. Since the geodatabase needed to have a flexible storage capacity without the need for multiple editors, a file geodatabase was used.

The main operational requirement of the system was the script tool. It allowed the client to set the initial basin characteristics, calculate peak discharge rates, and retrieve the results.

Transitional requirements focused on data conversion, testing, system demonstration and documentation. These were included in the requirements to ensure that the client would know how to use and maintain the tool. New data layers created were transformed into the Nad_1927_Alaska_Albers_Meters to stay in compliance with the client's projection standards. There were multiple climate difference datasets calculated and 
scripts developed to ensure that the functional and non-functional requirements were met. A brief demonstration of the tool was also provided to the client, along with accompanying documentation. These documents included a DVD with all the necessary data, a help document for the climate anomaly and script, and a complete project report.

To comply with legislative requirements, all owner names that were associated with the climate data were removed from the geodatabase to maintain anonymity.

\subsection{System Design}

System design took the client's functional and non-functional requirements into consideration. The script tool was designed to be accessed from a computer with ArcGIS 10.0 having a geodatabase configured for data storage. The geodatabase and the script tool are the primary elements of the system design as shown in Figure 3-1.

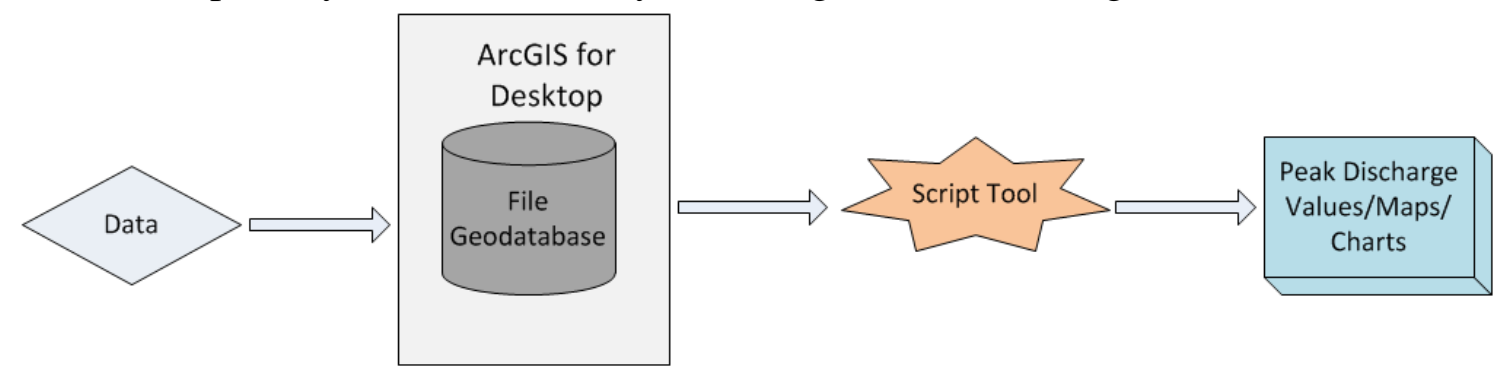

Figure 3-1: System Architecture

PythonWin needs to be installed to develop the Python scripts that are necessary for the calculation of peak discharges. The data that were required to meet the goals of the Yukon River Inter-Tribal Watershed Council were temperature, precipitation, drainage areas, areas of lakes and ponds, basin elevations, linkage design component, and area of forest. Within the geodatabase the data were divided into four feature datasets; namely climate, hydrology, natural features, and physical features. The design of the geodatabase allows the client to insert other datasets that may be useful in future work. The calculation of climate differences was done solely with ArcGIS; the tool to calculate the peak discharge values was created in Python script.

\subsection{Project Plan}

The client needed a geodatabase and climate change datasets at the beginning of the project. It was during the course of the project that the need for a tool to calculate peak discharge values was added.

\subsubsection{Original Plan}

The project phases include project define, project plan, project execute, project control, and project close. The phases were comprised of tasks " $\mathrm{T}$ " and milestones " $\mathrm{M}$ ". The original plan involved the development of two deliverables a geodatabase and a climate difference. The geodatabase was designed for the storage of all relevant climate datasets for the YRITWC, and also provided information on climate change difference presented in Table 3. 
Table 3. Initial Project Plan

\begin{tabular}{|c|l|c|c|c|}
\hline Phase & \multicolumn{1}{|c|}{ Task } & Start & End & $\begin{array}{c}\text { Duration } \\
\text { (days) }\end{array}$ \\
\hline $\mathbf{1}$ & Define & $\mathbf{2 / 7 / 2 0 1 1 2}$ & $\mathbf{3 / 3 / 2 0 1 2}$ & $\mathbf{2 6}$ \\
\hline T & Project Selection & $2 / 7 / 2012$ & $2 / 11 / 2012$ & 4 \\
\hline T & Project Approval & $2 / 7 / 2012$ & $2 / 10 / 2012$ & 4 \\
\hline T & Develop a Project Proposal & $3 / 2 / 2012$ & $3 / 25 / 2012$ & 22 \\
\hline M & Present Project Proposal to Client & $3 / 19 / 2012$ & $3 / 19 / 2012$ & - \\
\hline $\mathbf{2}$ & Plan & $\mathbf{4 / 3 / 2 0 1 2}$ & $\mathbf{5 / 1 6 / 2 0 1 2}$ & $\mathbf{4 5}$ \\
\hline T & Data Collection & $4 / 3 / 2012$ & $4 / 22 / 2012$ & 20 \\
\hline T & Assess User Needs & $4 / 4 / 2012$ & $4 / 9 / 2012$ & 6 \\
\hline T & Develop Information Products & $4 / 10 / 2012$ & $4 / 25 / 2012$ & 16 \\
\hline T & Assess User Requirements & $5 / 1 / 2012$ & $5 / 16 / 2010$ & 16 \\
\hline $\mathbf{3}$ & Execute & $\mathbf{5 / 1 7 / 2 0 1 2}$ & $\mathbf{9 / 3 0 / 2 0 1 2}$ & $\mathbf{1 0 7}$ \\
\hline T & Develop Geodatabase & $5 / 17 / 2012$ & $5 / 26 / 2012$ & 10 \\
\hline T & Create/Update Metadata & $5 / 17 / 2012$ & $6 / 27 / 2012$ & 11 \\
\hline M & Submit Database Design for Review & $6 / 4 / 2012$ & $6 / 4 / 2012$ & - \\
\hline T & Calculate Climate Anomalies & $6 / 24 / 2012$ & $7 / 24 / 2012$ & 30 \\
\hline T & Calculate Discharge & $7 / 25 / 12$ & $9 / 30 / 12$ & 68 \\
\hline T & Create Script & $7 / 25 / 12$ & $9 / 30 / 12$ & 68 \\
\hline $\mathbf{4}$ & Monitor & $\mathbf{1 0 / 1 / 2 0 1 0}$ & $\mathbf{1 1 / 2 2 / 1 2}$ & $\mathbf{5 1}$ \\
\hline T & Test Design/ Functions & $10 / 2 / 2012$ & $10 / 10 / 2012$ & 9 \\
\hline M & Design Release to Client & $10 / 15 / 2012$ & $10 / 15 / 2012$ & - \\
\hline T & Revisions & $10 / 15 / 2012$ & $10 / 25 / 2012$ & 11 \\
\hline T & Test Design/ Functions & $10 / 25 / 2012$ & $10 / 3 / 2012$ & 6 \\
\hline M & Design Release to Client & $11 / 5 / 2012$ & $11 / 3 / 2012$ & - \\
\hline T & Revisions & $11 / 5 / 2012$ & $11 / 10 / 2012$ & 5 \\
\hline T & Finalize Model Deliverables & $11 / 10 / 2012$ & $11 / 22 / 2012$ & 13 \\
\hline T & Finalize Project Documentation & $10 / 2 / 2012$ & $11 / 22 / 2012$ & 51 \\
\hline $\mathbf{5}$ & Close & $\mathbf{1 2 / 3 / 2 0 1 2}$ & $\mathbf{1 2 / 1 1 / 2 0 1 2}$ & $\mathbf{1 0}$ \\
\hline M & Present Project & $11 / 30 / 2012$ & $11 / 30 / 2012$ & - \\
\hline T & Deliver Project Solution to Client & $12 / 3 / 2012$ & $12 / 11 / 2012$ & 10 \\
\hline & & & & \\
\hline
\end{tabular}




\subsubsection{Revised Plan}

The revised scope included the calculation of peak discharge values. This change affected the starting time for each phase. To complete the planning phase, new information products, user needs, and system requirements were developed. The researcher had to search for new data for the calculation of peak discharge values, which were then preprocessed. The execution phase experienced some delay, as the feature classes within the geodatabase needed to be reprocessed, peak discharge values to be calculated, a script was written and climate differences calculated. Due to the addition of the requirement to calculate peak discharge values, the monitor phase was also extended. Despite all the time delays in many of the phases, the overall project completion date was not significantly changed. 


\section{Chapter 4 - Database Design}

The project database design is discussed in this chapter which also explains the conceptual and logical data models. There follows a description of the data sources and data preparation procedures. The chapter concludes with an overall summary.

\subsection{Conceptual Data Model}

The conceptual model looks at an abstraction of real world entities and identifies the features, their attributes, and the relationships between them. The Unified Modeling Language (UML) was used to create the structure of the conceptual model for the project (Figure 4-1).

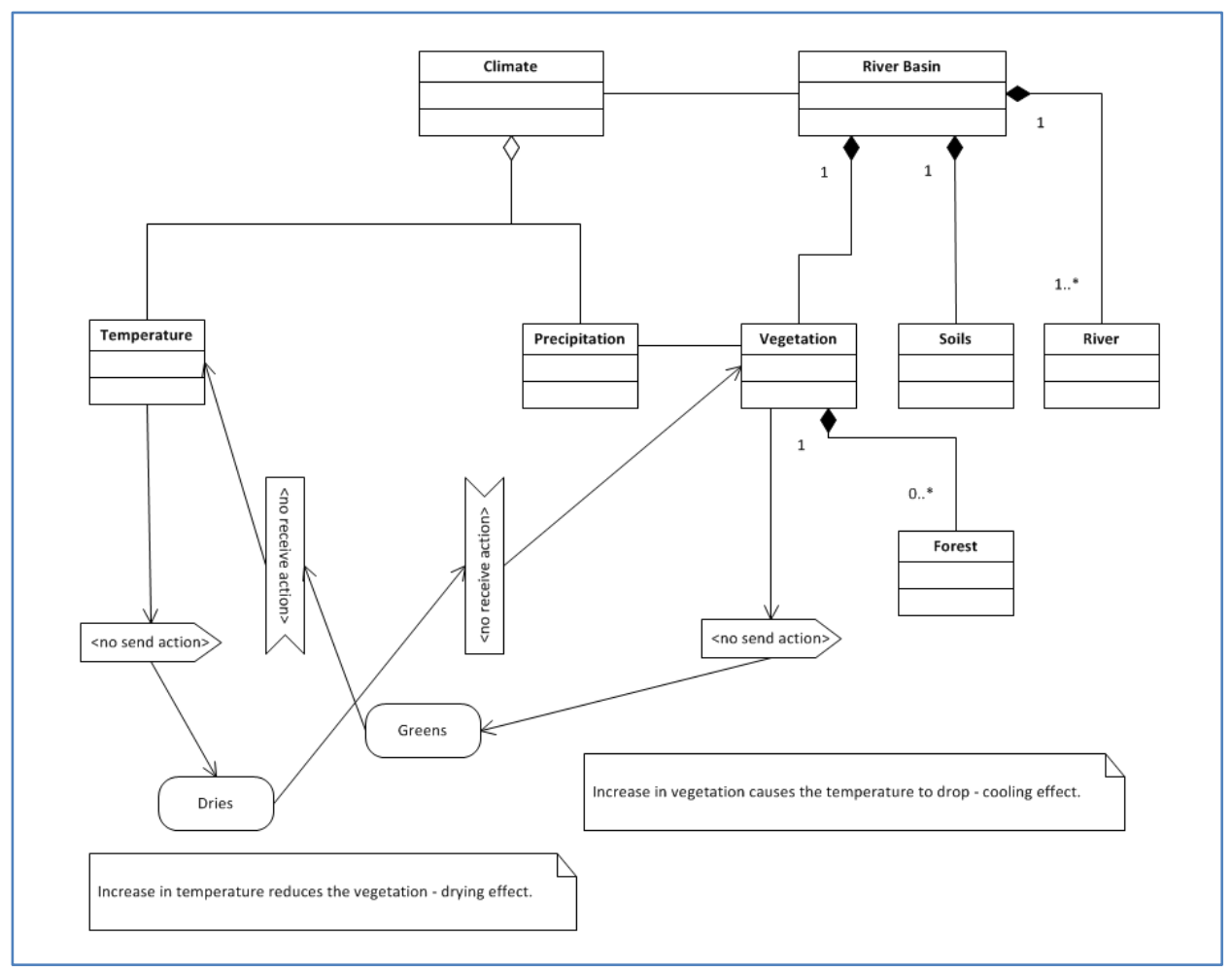

Figure 4-1: The Conceptual Data Model

The client needed climate change scenarios, peak discharges, and a geodatabase for the Yukon River Basin. These are divided into the following themes: temperature, precipitation, river basin, river, soils, vegetation and forest.

\subsection{Logical Data Model}

This step in the design process was to develop a logical data model, which describes the actual structure of the database. A file geodatabase was chosen for this project because of its capacity to store large amounts of data, multiple feature classes, and tables. The logical data model of this project contained two datasets: climate change and discharge. It 
also included the associated feature datasets, feature classes, and tables. The logical data model (Figure 4-2) was created with the Unified Modeling Language.

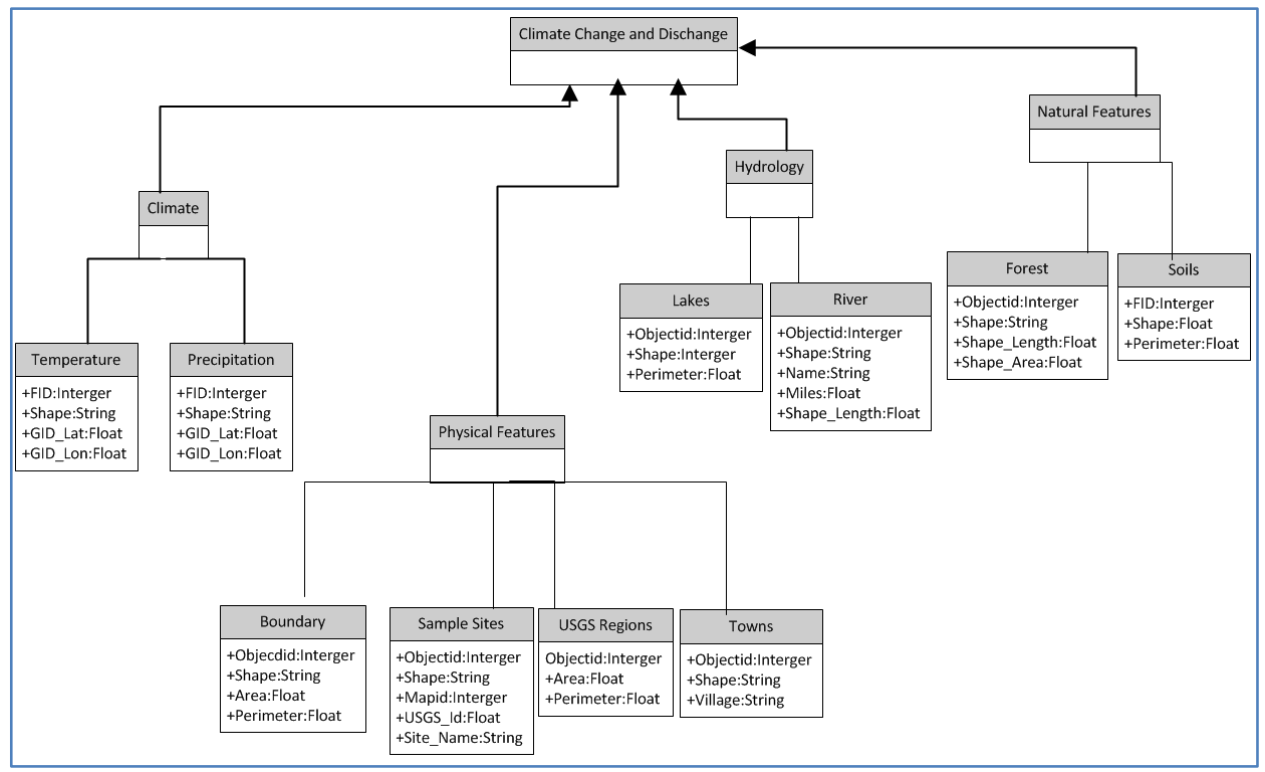

Figure 4-2: Logical Data Model

\subsection{Data Sources}

The data for this project came from a variety of sources. The datasets were cleaned and organized in a geodatabase. The required datasets were enumerated and described in the Master Input Data List (MIDL) before the geodatabase was developed see Table 4.

Table 4. YRITWC Climate Change and Discharge MIDL

\begin{tabular}{|c|c|c|c|c|}
\hline $\begin{array}{l}\text { Data Set } \\
\text { Name }\end{array}$ & Description & $\begin{array}{l}\text { Data } \\
\text { Type }\end{array}$ & Data Source & $\begin{array}{l}\text { Data Processing } \\
\text { (if available) }\end{array}$ \\
\hline $\begin{array}{l}\text { Yukon } \\
\text { Boundary }\end{array}$ & $\begin{array}{l}\text { Polygon } \\
\text { feature class } \\
\text { of the Yukon } \\
\text { River Basin } \\
\text { Boundary }\end{array}$ & $\begin{array}{l}\text { Shape } \\
\text { File }\end{array}$ & $\begin{array}{l}\text { Provided by the } \\
\text { client originally } \\
\text { compiled by } \\
\text { USGS }\end{array}$ & \\
\hline $\begin{array}{l}\text { Yukon } \\
\text { Lakes }\end{array}$ & $\begin{array}{l}\text { Polygon } \\
\text { feature class } \\
\text { of the Yukon } \\
\text { River Basin }\end{array}$ & $\begin{array}{l}\text { Shape } \\
\text { File }\end{array}$ & $\begin{array}{l}\text { Provided by the } \\
\text { client originally } \\
\text { compiled by } \\
\text { USGS }\end{array}$ & \\
\hline $\begin{array}{l}\text { Sample } \\
\text { Sites }\end{array}$ & $\begin{array}{l}\text { Point feature } \\
\text { class of the } \\
\text { Yukon River } \\
\text { Basin }\end{array}$ & $\begin{array}{l}\text { Shape } \\
\text { File }\end{array}$ & $\begin{array}{l}\text { Provided by the } \\
\text { client originally } \\
\text { compiled by } \\
\text { USGS }\end{array}$ & $\begin{array}{l}\text { Projected to } \\
\text { NAD_1927_Alaska_Alber } \\
\text { s_Meters }\end{array}$ \\
\hline Sub & Polygon & Shape & Provided by the & Projected to \\
\hline
\end{tabular}




\begin{tabular}{|c|c|c|c|c|}
\hline $\begin{array}{l}\text { Data Set } \\
\text { Name }\end{array}$ & Description & $\begin{array}{l}\text { Data } \\
\text { Type }\end{array}$ & Data Source & $\begin{array}{l}\text { Data Processing } \\
\text { (if available) }\end{array}$ \\
\hline Watershed & $\begin{array}{l}\text { feature class } \\
\text { of the Yukon } \\
\text { River Basin } \\
\end{array}$ & File & $\begin{array}{l}\text { client originally } \\
\text { compiled by } \\
\text { USGS }\end{array}$ & $\begin{array}{l}\text { NAD_1927_Alaska_Alber } \\
\text { s_Meters }\end{array}$ \\
\hline $\begin{array}{l}\text { Yukon } \\
\text { River }\end{array}$ & $\begin{array}{l}\text { Line feature } \\
\text { class that } \\
\text { shows the } \\
\text { river flowing } \\
\text { across the } \\
\text { Yukon Basin }\end{array}$ & $\begin{array}{l}\text { Shape } \\
\text { File }\end{array}$ & $\begin{array}{l}\text { Provided by the } \\
\text { client originally } \\
\text { compiled by } \\
\text { USGS }\end{array}$ & \\
\hline Soils & $\begin{array}{l}\text { Polygon } \\
\text { feature class } \\
\text { of the Yukon } \\
\text { River Basin }\end{array}$ & $\begin{array}{l}\text { Shape } \\
\text { File }\end{array}$ & $\begin{array}{l}\text { Provided by the } \\
\text { client originally } \\
\text { compiled by } \\
\text { USGS }\end{array}$ & $\begin{array}{l}\text { Projected to } \\
\text { NAD_1927_Alaska_Alber } \\
\text { s_Meters }\end{array}$ \\
\hline Towns & $\begin{array}{l}\text { Point feature } \\
\text { class of the } \\
\text { towns in and } \\
\text { around the } \\
\text { Yukon River } \\
\text { Basin }\end{array}$ & $\begin{array}{l}\text { Shape } \\
\text { File }\end{array}$ & $\begin{array}{l}\text { Provided by the } \\
\text { client originally } \\
\text { compiled by } \\
\text { USGS }\end{array}$ & \\
\hline Forest & $\begin{array}{l}\text { Polygon } \\
\text { feature class } \\
\text { of the Yukon } \\
\text { River Basin }\end{array}$ & $\begin{array}{l}\text { Shape } \\
\text { File }\end{array}$ & $\begin{array}{l}\text { http://www.cec.o } \\
\text { rg/Page.asp. }\end{array}$ & $\begin{array}{l}\text { Down load, project, } \\
\text { interpolate, clipped to the } \\
\text { study area, converted to } \\
\text { polygon, and aggregate } \\
\text { polygon }\end{array}$ \\
\hline $\begin{array}{l}\text { USGS } \\
\text { Discharge } \\
\text { Regions }\end{array}$ & $\begin{array}{l}\text { Polygon } \\
\text { feature class } \\
\text { of Alaska } \\
\text { and } \\
\text { Conterminou } \\
\text { s Basins of } \\
\text { Canada }\end{array}$ & $\begin{array}{l}\text { Paper } \\
\text { Hard } \\
\text { Copy }\end{array}$ & $\begin{array}{l}\text { USGS Water } \\
\text { Resources } \\
\text { Investigations } \\
\text { Reports 93-4197 }\end{array}$ & $\begin{array}{l}\text { Scanned, geoference, } \\
\text { digitized and Projected to } \\
\text { NAD_1927_Alaska_Alber } \\
\text { s_Meters }\end{array}$ \\
\hline Temperature & $\begin{array}{l}\text { Polygon } \\
\text { feature class } \\
\text { of Yukon } \\
\text { River Basin } \\
\end{array}$ & $\begin{array}{l}\text { Shape } \\
\text { File }\end{array}$ & $\begin{array}{l}\text { UCAR Website } \\
\text { http://gisclimatec } \\
\text { hange.ucar.edu/ }\end{array}$ & $\begin{array}{l}\text { Down load, project, } \\
\text { interpolate, clipped to the } \\
\text { study area, and zonal } \\
\text { statistics }\end{array}$ \\
\hline Precipitation & $\begin{array}{l}\text { Polygon } \\
\text { feature class } \\
\text { of Yukon } \\
\text { River Basin }\end{array}$ & $\begin{array}{l}\text { Shape } \\
\text { File }\end{array}$ & $\begin{array}{l}\text { UCAR Website } \\
\text { http://gisclimatec } \\
\text { hange.ucar.edu/ }\end{array}$ & $\begin{array}{l}\text { Down load, project, } \\
\text { interpolate, clipped to the } \\
\text { study area, and zonal } \\
\text { statistics }\end{array}$ \\
\hline
\end{tabular}

The client provided seven feature classes for the project area, which were originally compiled by the USGS from various sources and had varying degrees of documentation. The remaining four feature classes -temperature, precipitation, USGS discharge regions, and forest- needed to be collected and compiled. 


\subsection{Data Scrubbing and Loading}

The datasets for this project covered a range of geographic areas with different projections. They needed to be cleaned before loaded into the database. The projection for this geodatabase was determined to be the NAD_1927_Alaska_Albers_Meters. This was chosen because the Yukon River Basin data were provided on this projection. For the purposes of this project, three feature classes - temperature, precipitation, and forest were clipped to the Yukon boundary. Once the data preparation process was completed, the feature classes were loaded into the ArcGIS file geodatabase. In addition to feature classes clipped to the project area, the original feature classes were also loaded into the geodatabase for use in future projects as presented in Figure 4-3.

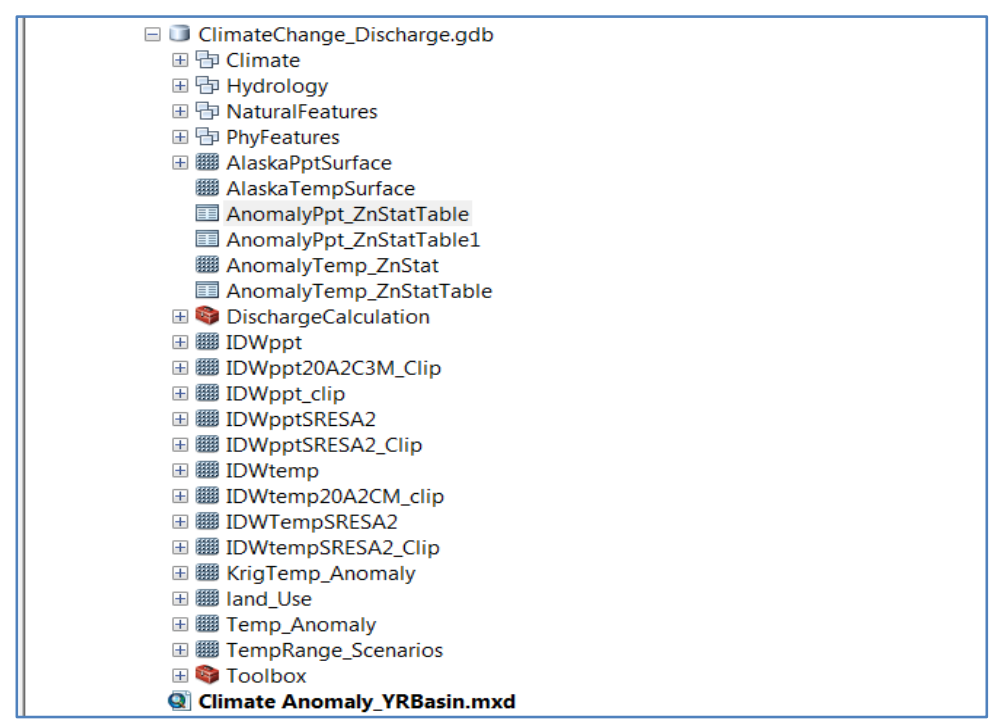

Figure 4-3: Final Geodatabase

\subsection{Summary}

The file geodatabase used for the project was discussed in this chapter. The conceptual model was used to identify the features and their attributes, and the relationships among them. The logical data model showed that the data used in this project were feature classes. This determined the schema type to be used in the geodatabase. The essential feature classes were compiled and loaded into a geodatabase. The client provided most of the feature classes which needed little processing before they were loaded into the geodatabase. The other feature classes were produced after being scanned, georeferenced, digitized, projected, interpolated, clipped to the project area, and processed. 


\section{Chapter 5 - Implementation}

The Yukon River Basin climate change scenarios project tried to make spatial information more interpretable and the calculation of peak discharges straightforward for the client. The project utilized the ArcGIS software and PythonWin. The first process had to determine the changes in temperature and precipitation between the 1980-1999 period, known in the climate change community as the 20th Century, and the 2040-2059 period, known in the climate change community as the Mid-Century. The script tool was created, and the peak discharges were calculated. The peak discharge was determined for the MidCentury period based on projected changes in minimum mean January temperature and mean annual precipitation.

\subsection{Data Processing}

This section describes the process of obtaining and processing the data for use in this project.

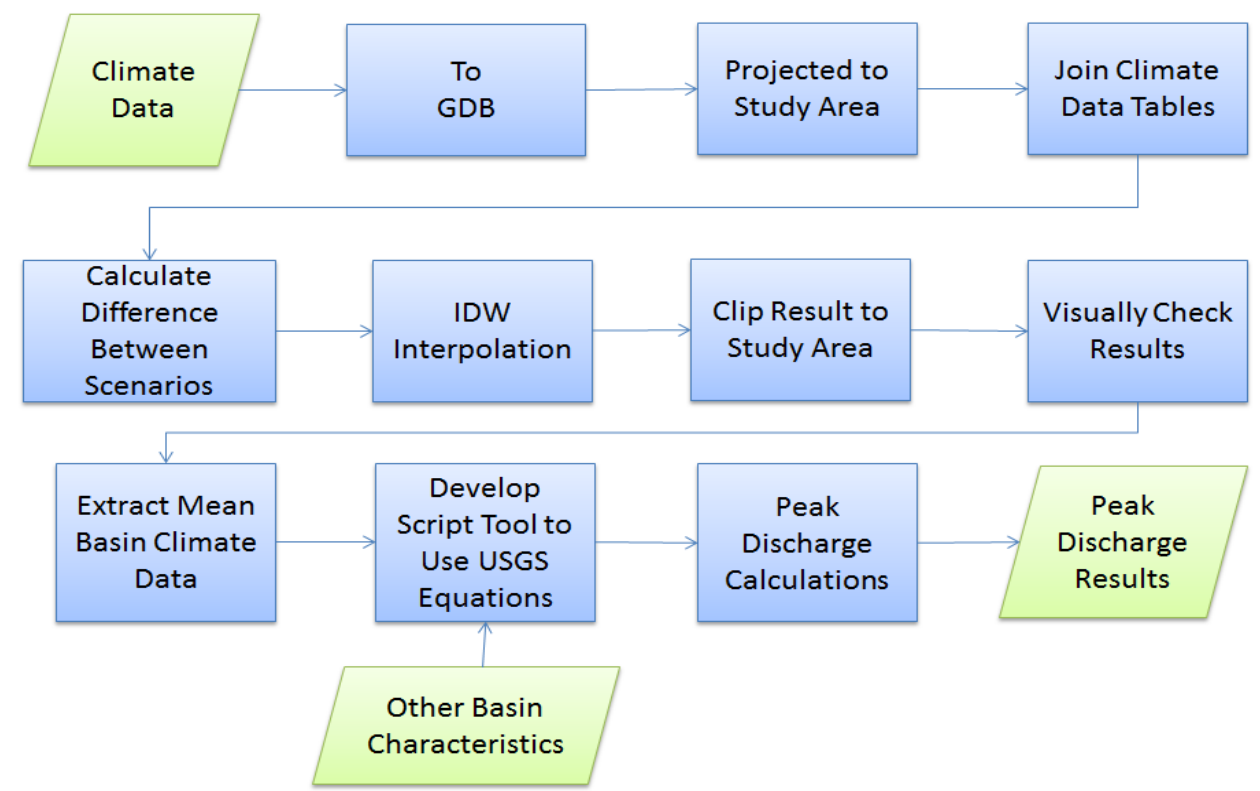

Figure 5-1: Project Implementation Work Flow

Figure 5-1 shows the general workflow of the implementation, and the rest of the chapter explains the workflow in detail.

\subsubsection{Data Download and Projection}

The datasets were derived from NCAR Community Climate System Model (CCSM), which is one of the most widely used global climate models. The CCSM was used with the 1980-1999 time period known in the climate community as the $20^{\text {th }}$ Century, and the 
High A2 scenario for the 2040-2059 time period known in the climate community as Mid-Century. The mean January temperature for both time periods was downloaded with specifications as illustrated in Figures 5-2 and 5-3 respectively.

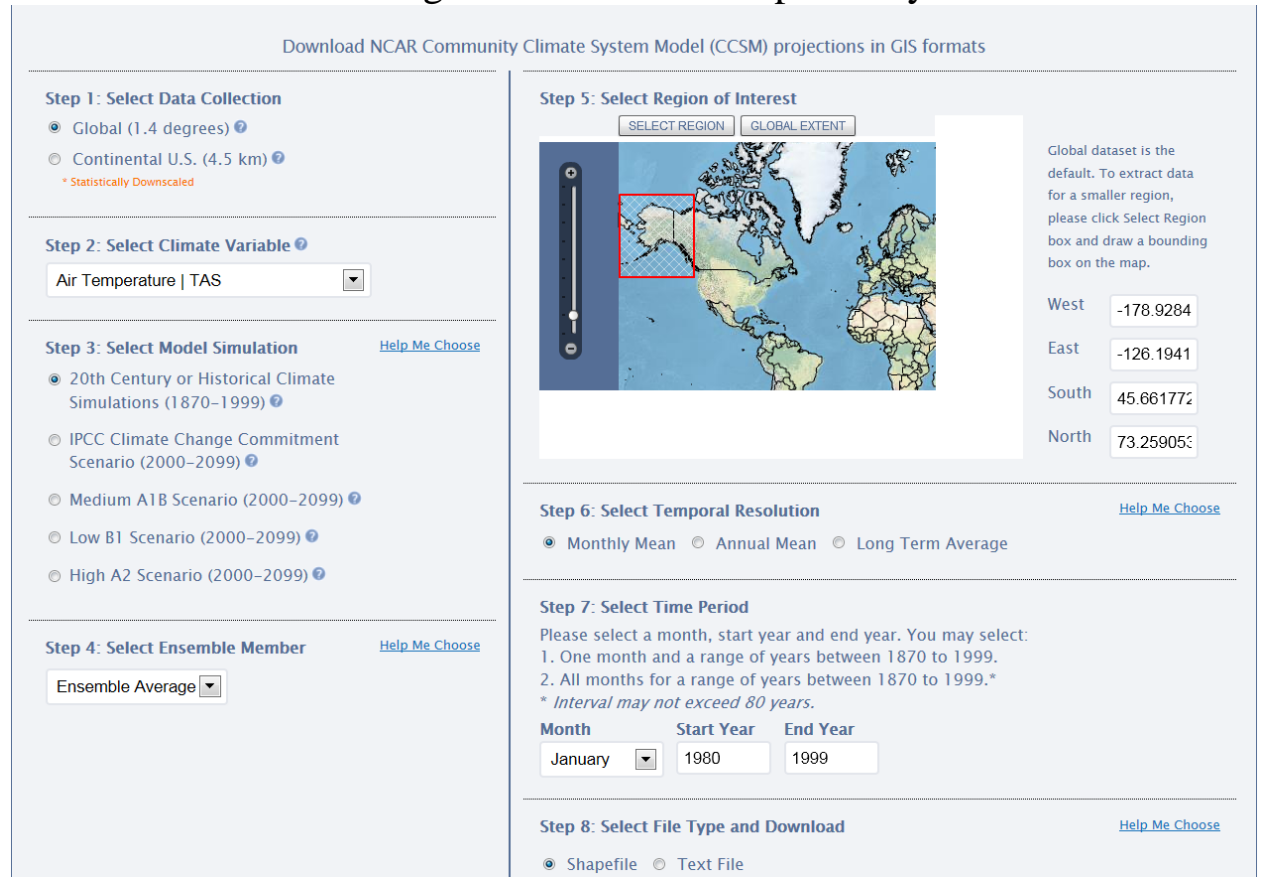

Figure 5-2: Mean January Temperature for the 20th Century

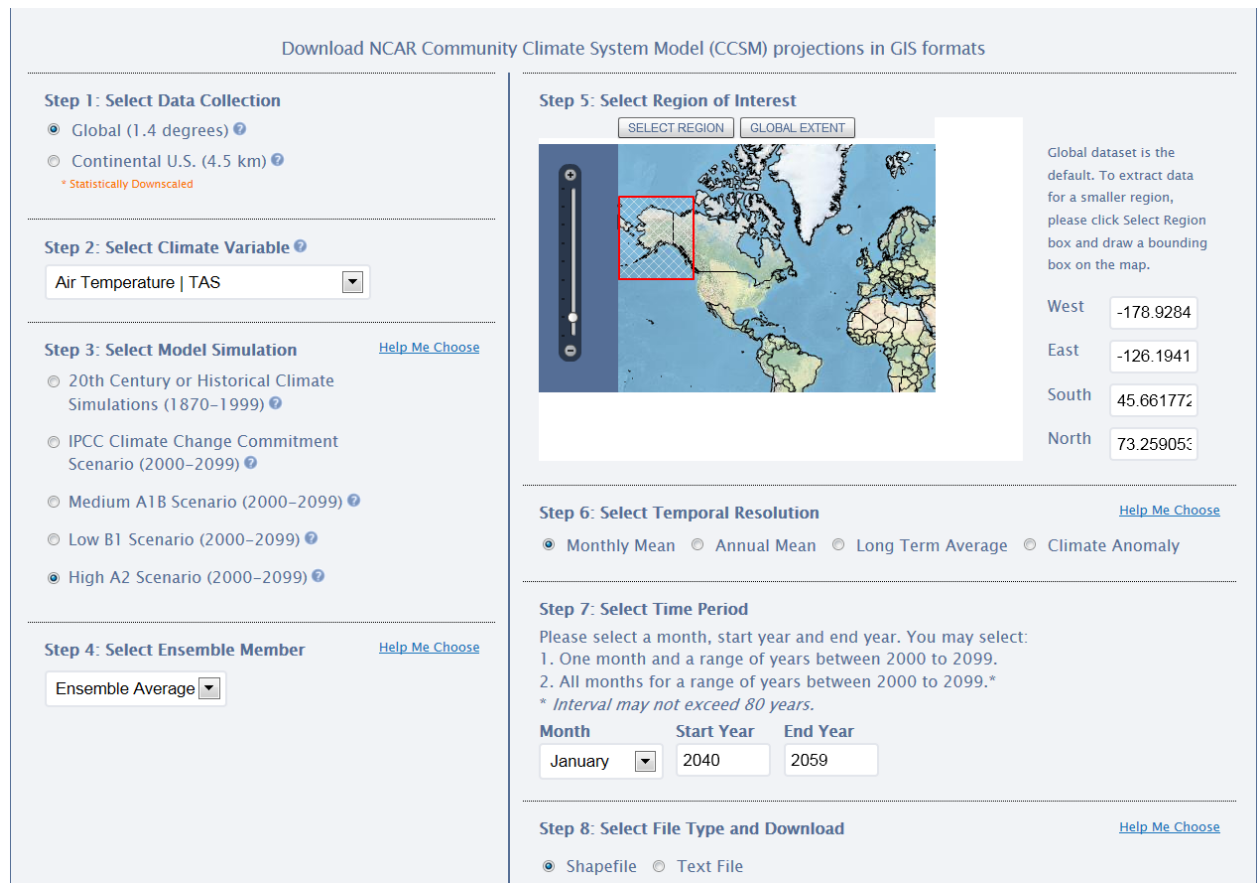

Figure 5-3: Mean January Temperature for the Mid-Century

The mean annual precipitation for both time periods was downloaded with specifications as shown in Figures 5-4 and 5-5 respectively. 


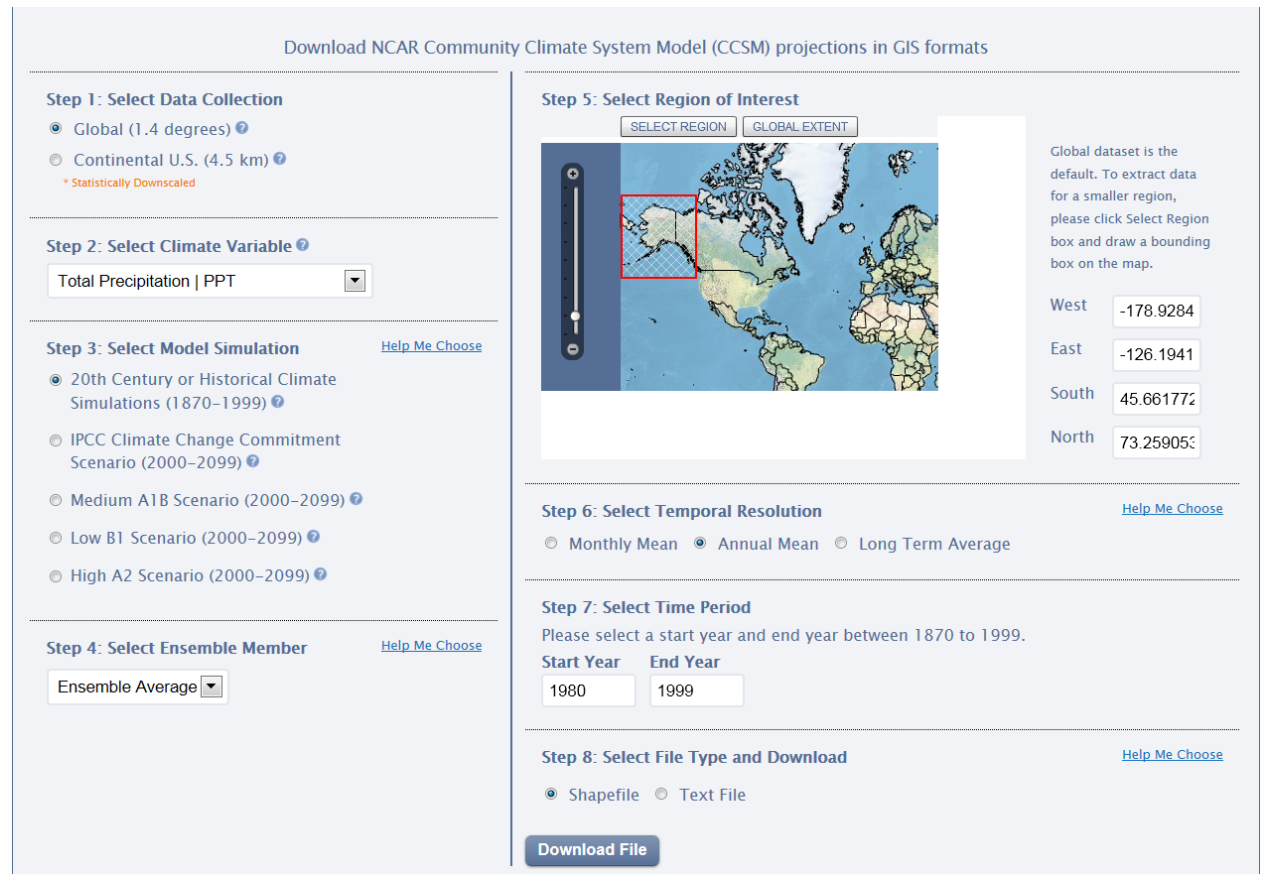

Figure 5-4: Mean Annual Precipitation for the 20th Century

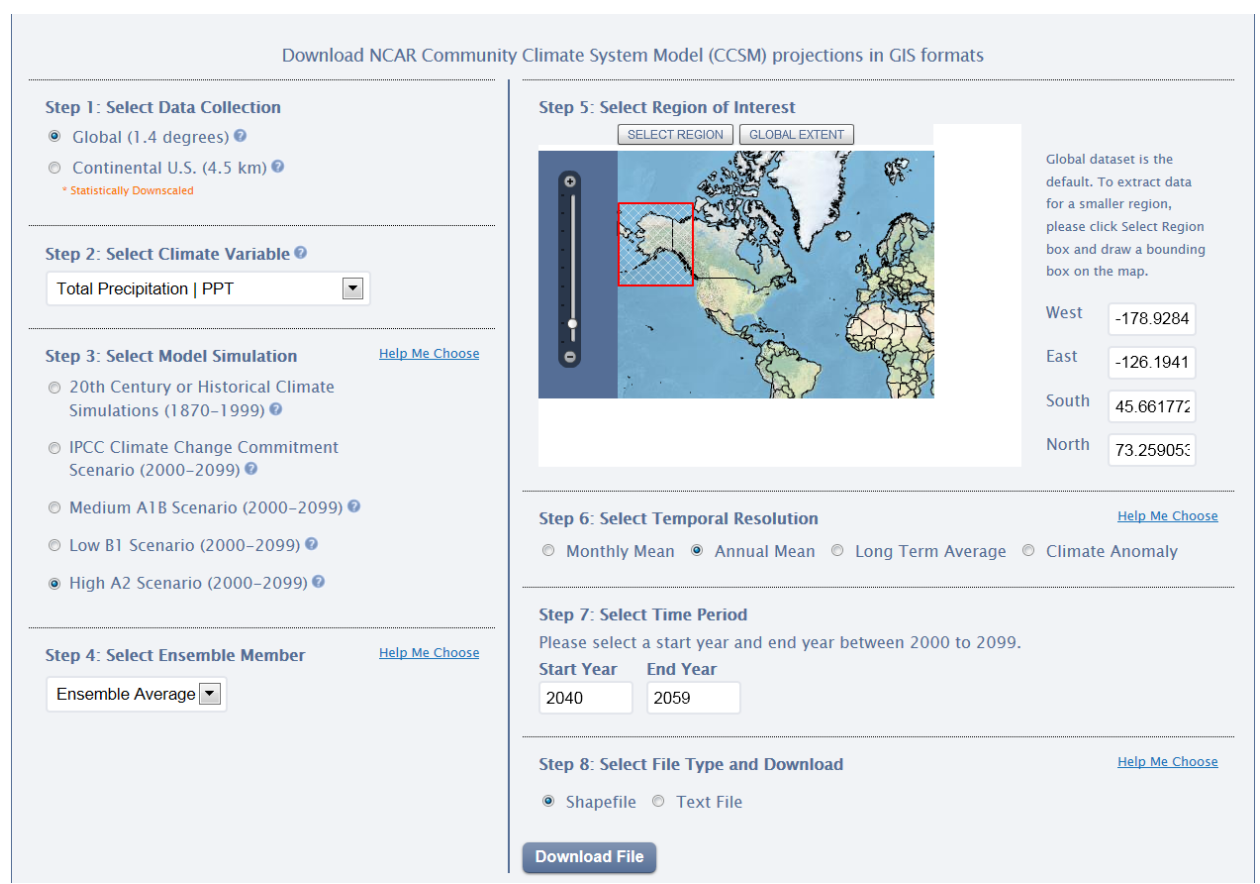

Figure 5-5: Mean Annual Precipitation for the Mid-Century

The CCSM outputs contained information for each point about change in mean annual precipitation and mean January temperature for the $20^{\text {th }}$ Century and the MidCentury periods. The point data were re-projected into NAD_1927_Alaska_Albers_Meters, the coordinate system used in the Yukon River boundary dataset provided by the client. 


\subsubsection{Climate Data Conversion}

This section describes the methods used in the data conversion to make it ready for use in this project. The attribute tables for the mean monthly temperature for the $20^{\text {th }}$ Century and Mid-Century periods were joined and the differences were calculated using the field calculator. These were averaged into 20 yearly forecast grids. The differences in temperature were converted from degrees Kelvin to degrees Fahrenheit as shown in Figure 5-6.

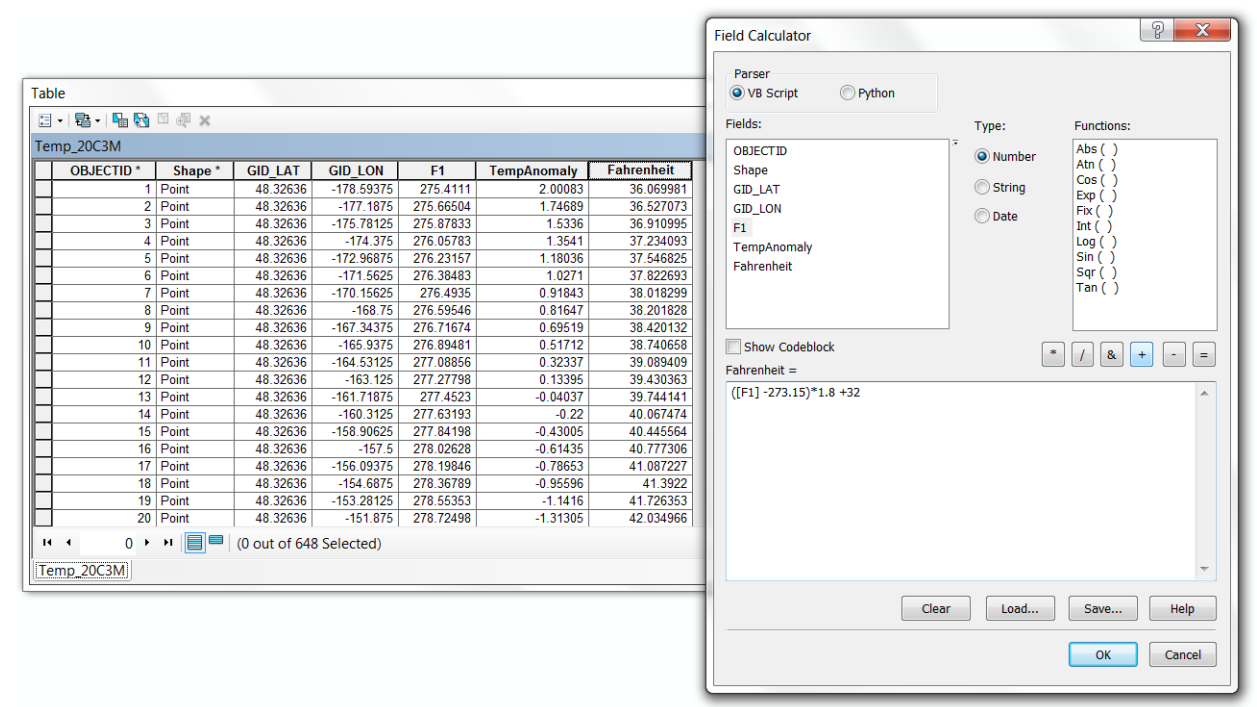

Figure 5-6: Join Tables and Field Calculator on Temperature

The final step was to establish a baseline from the data. Baselines are historical norms or standards, based on a reference series of years. The prediction data were expressed as offsets of the NCAR Community Climate System Model (CCSM). Baselines are used in most climate change research; forecast values were often specified as offsets above or below a specified baseline.

The attribute tables for the mean annual monthly precipitation for the $20^{\text {th }}$ Century and Mid-Century periods were joined and the differences calculated using the field calculator as illustrated in Figure 5-7. 


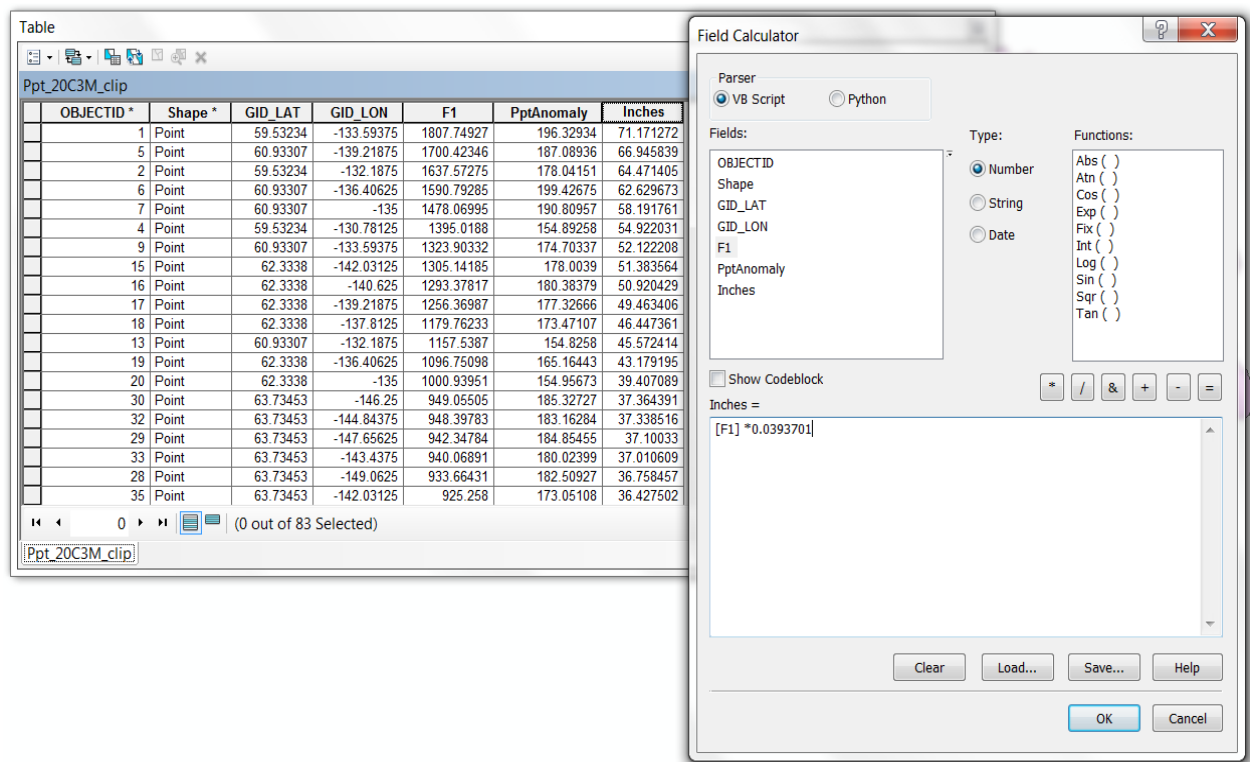

Figure 5-7: Join Tables and Field Calculator on Precipitation

The mean monthly temperature and mean annual precipitation for the data points for the $20^{\text {th }}$ Century and Mid-Century were transformed into a continuous grid (Figure 5-8) with the Inverse Distance Weighted (IDW) interpolation routine, as recommended by experts from NCAR.

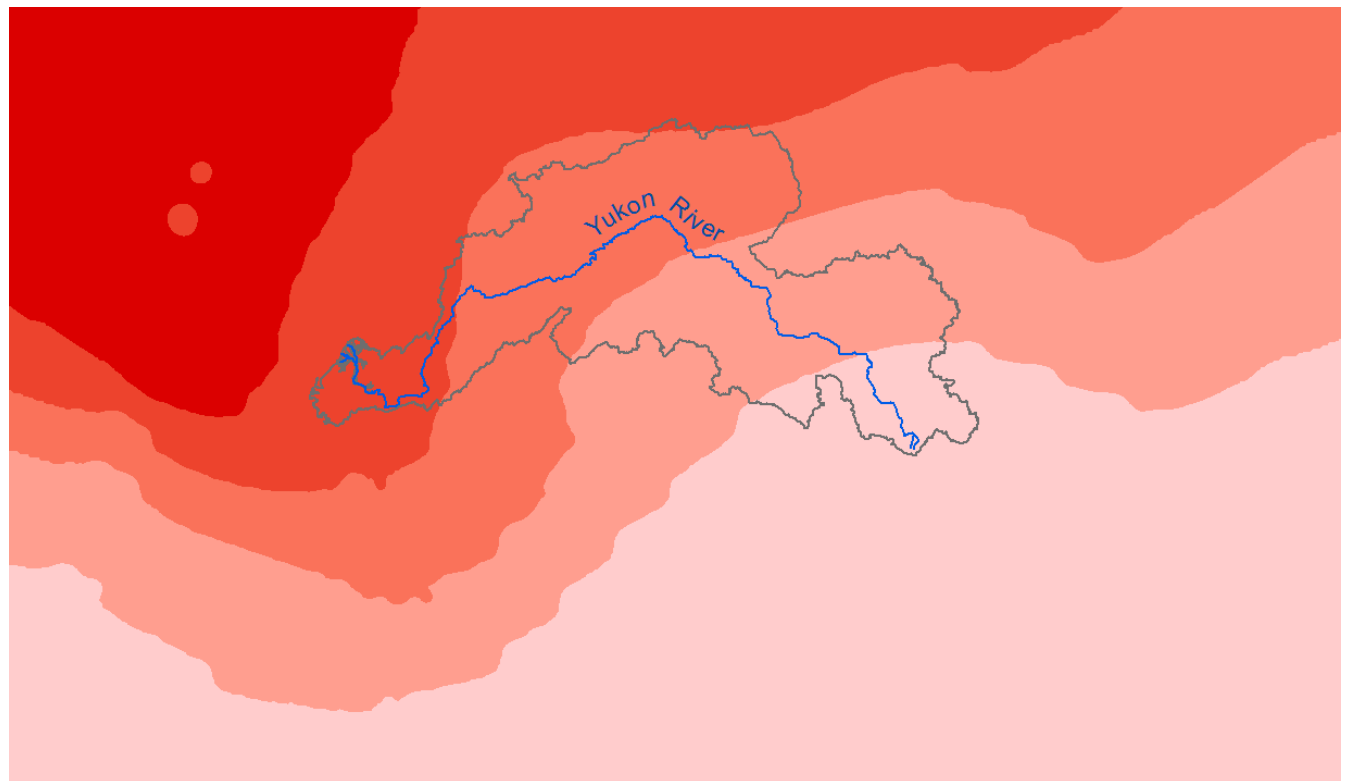

Figure 5-8: Inverse Distance Weighted (IDW) for Temperature Difference

The mean monthly temperature and the mean annual monthly precipitation gridded datasets for the $20^{\text {th }}$ Century and Mid-Century periods were clipped to the boundary of the Yukon River Basin as shown on Figure 5-9. 


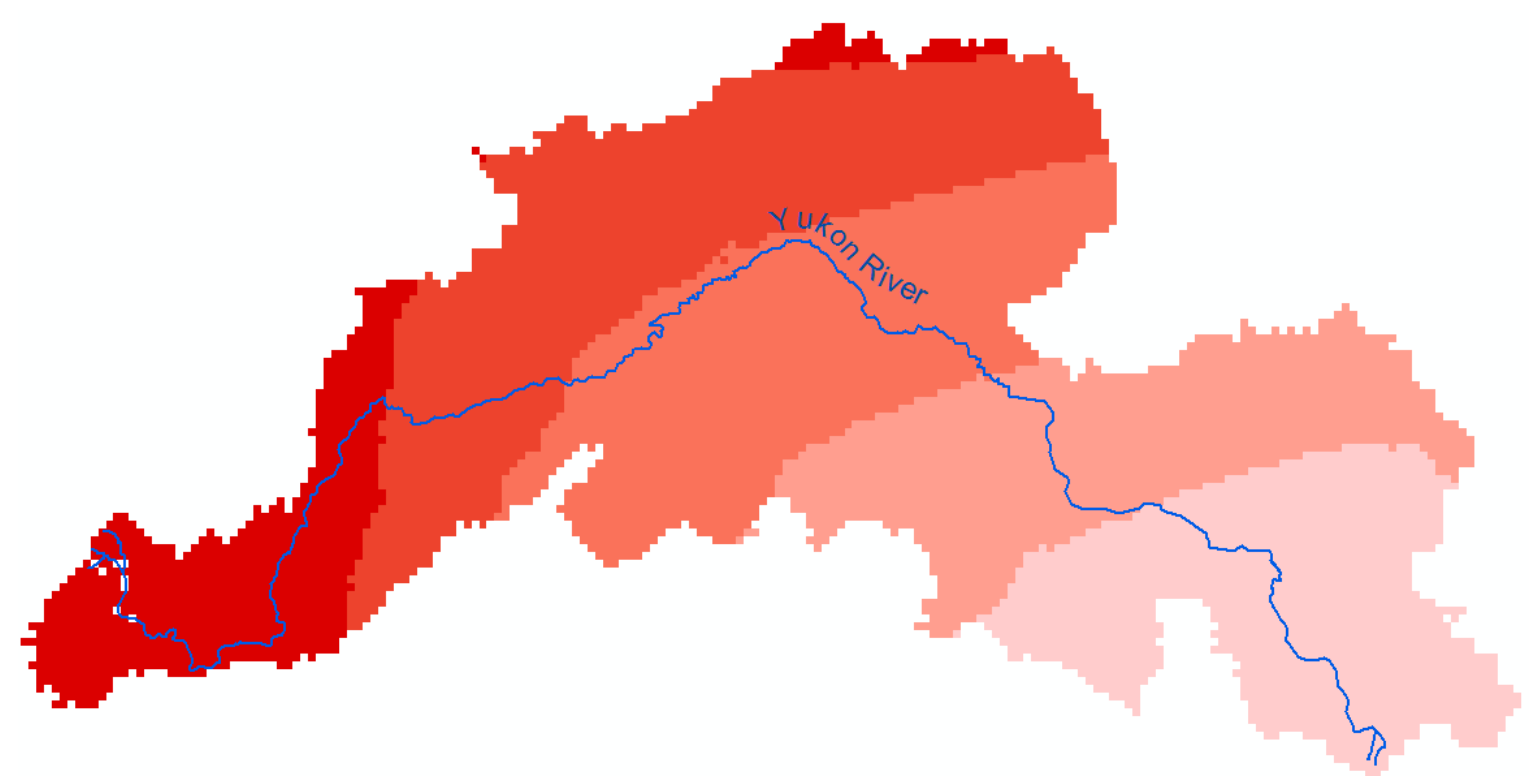

Figure 5-9: Clipped Temperature Difference

\subsubsection{Temperature Range 20th Century and Mid-Century Scenarios}

The temperature ranges for the $20^{\text {th }}$ Century and the Mid-Century periods were determined. This was done using a field calculator, by subtracting the 20 year mean monthly temperature for the $20^{\text {th }}$ Century from the mean monthly temperature for the Mid-Century. This produced raster datasets representing the climate differences between $20^{\text {th }}$ Century and Mid-Century periods (Figure 5-10) shows the calculation using ArcGIS Field Calculator.

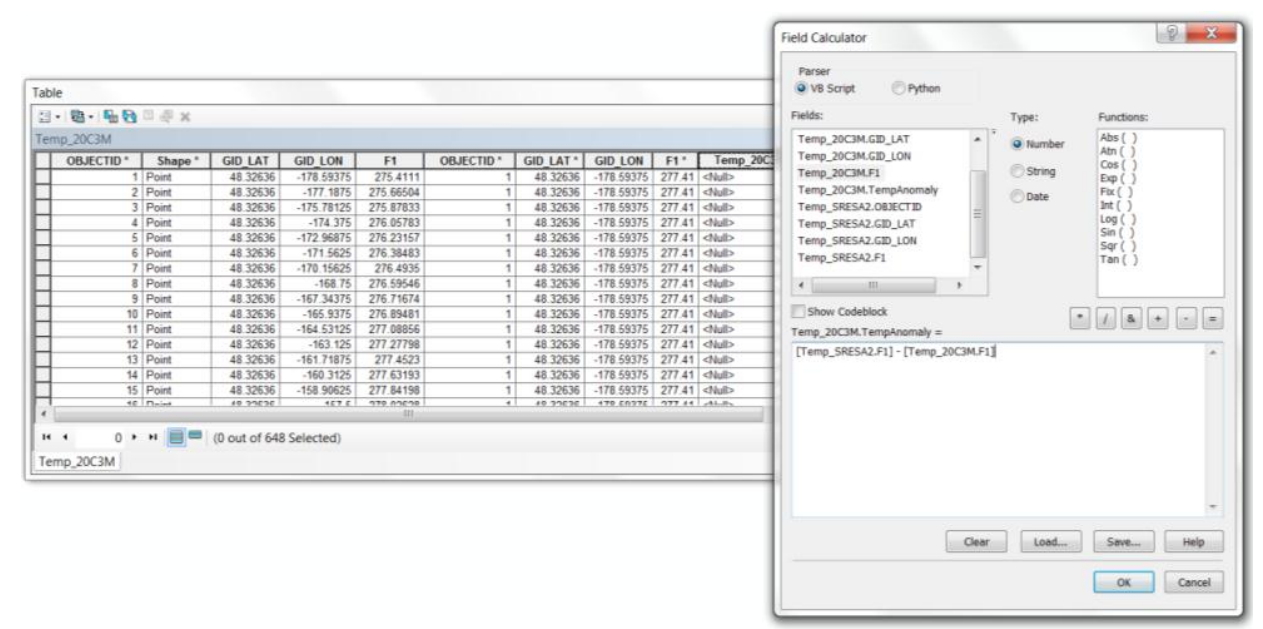

Figure 5-10: Calculating the Temperature Difference Dataset

\subsubsection{Calculating the Temperature Change}

The data to be symbolized are the differences between the most current climate values and the projected climate values downloaded from the Community Climate System 
Model (CCSM). To reduce the year-to-year variability in climate, the averages were calculated for both 20 year periods as in Figure 5-11.

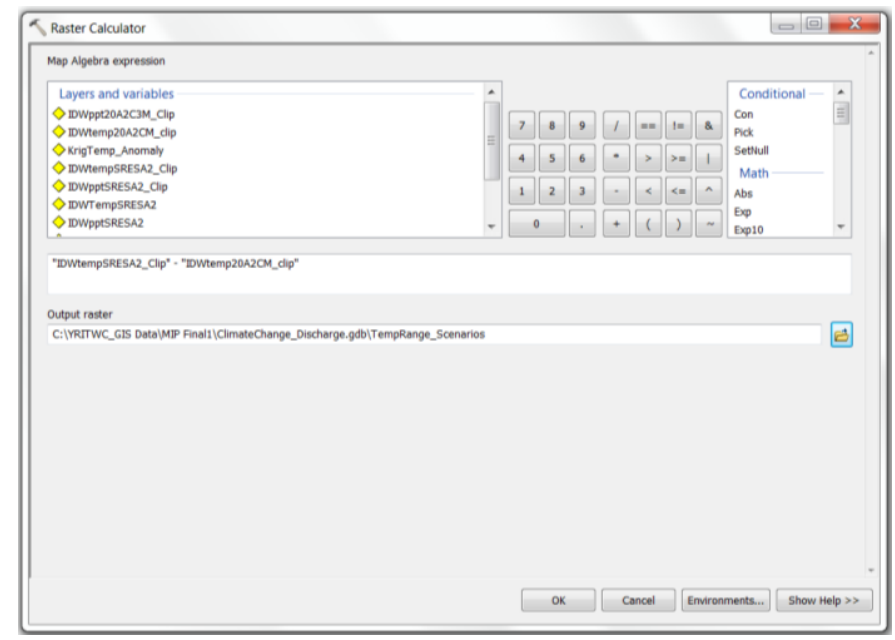

Figure 5-11: Calculating the Temperature Change Dataset

\subsubsection{Temperature Difference for USGS Regions}

Flood frequency region boundaries were compiled from a map in a USGS report on flood in the Alaska area as shown in 5-12.

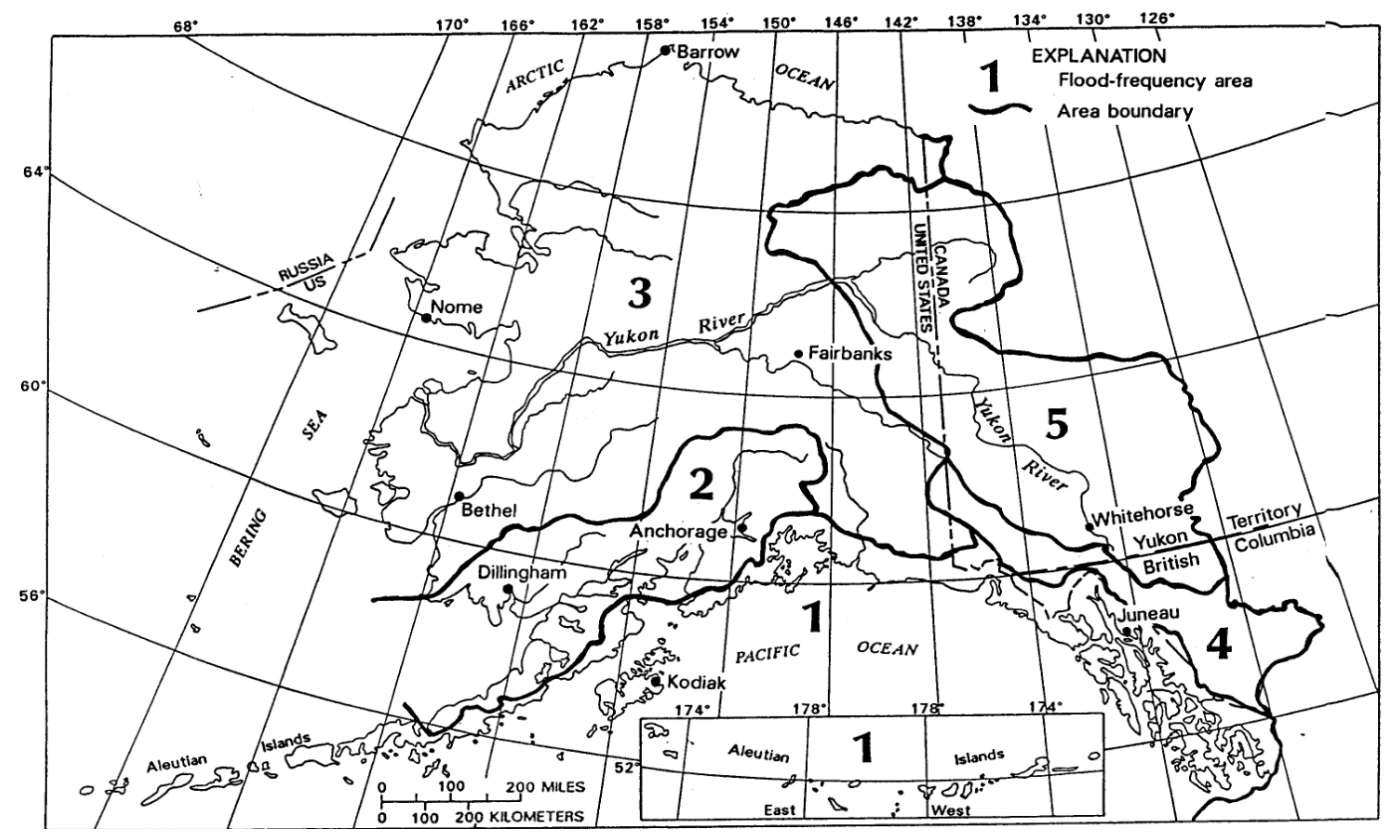

Source: Jones and Fahl (1994)

Figure 5-12: Scanned Yukon River Basin regions from the USGS Alaska report

The regions were intersected with the river basin layer to divide the basin into three similar flood frequencies. Statistics for the temperature changes between the two periods 
were calculated using the ArcGIS Zonal Statistics and Zonal Statistics as Table (see Figures 5-13 and 5-14).

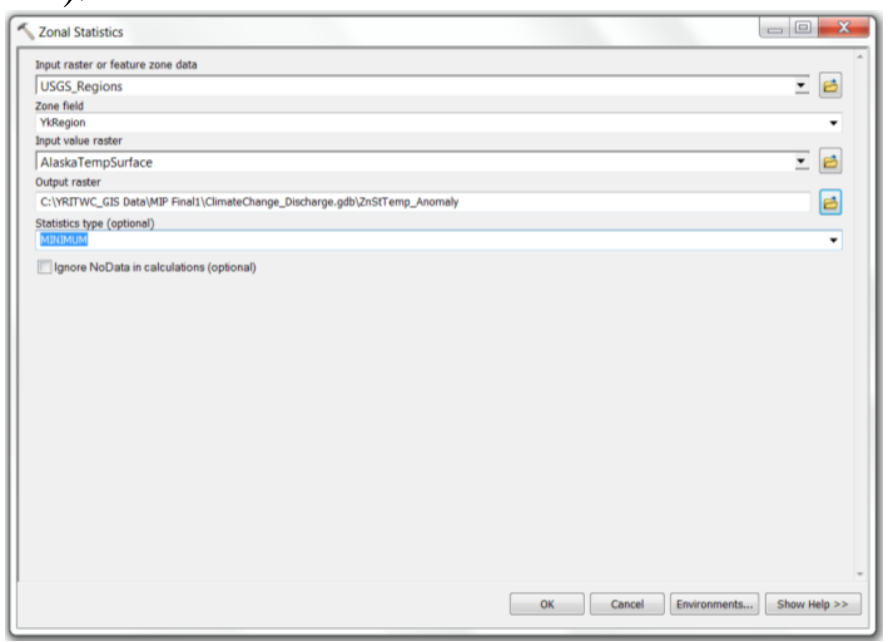

Figure 5-13: Zonal Statistics tool used to calculate Temperature differences

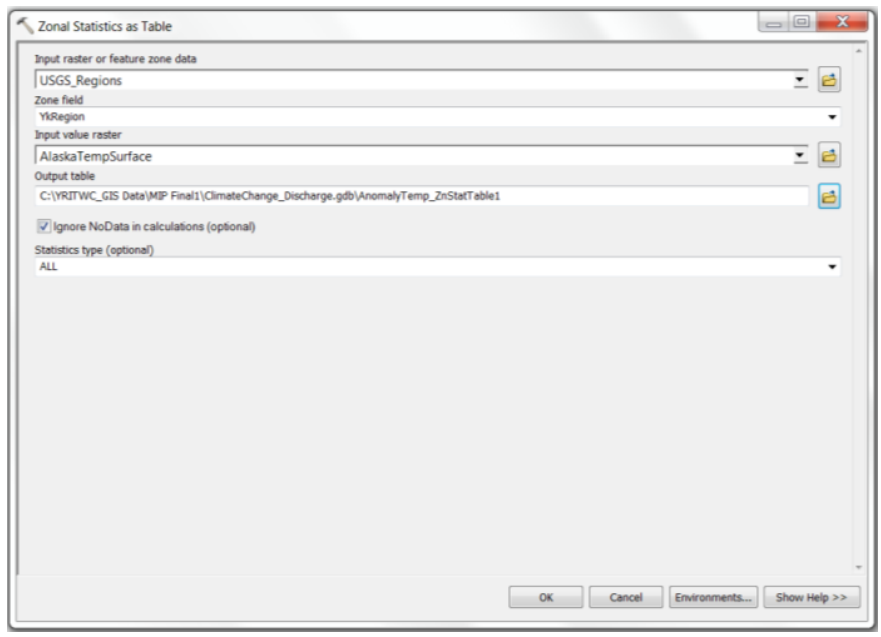

Figure 5-14: Temperature Zonal Statistics as Table tool

\subsection{Peak Discharge Calculation}

Peak discharges were calculated for the Yukon River Basin for 2-, 25-, and 50- year return periods (Q2, Q2 and Q50), using the USGS equations and the script tool developed in this project.

\subsubsection{USGS Regression Equations and Basin Characteristics}

Estimated discharge values were calculated using complex regression equations developed by the USGS for each region. The equations required basin characteristics including: drainage area, mean annual precipitation, area of lakes and ponds, and elevation. Area of forest and mean minimum January temperature were added for region 5 as specified in the USGS report. 


\subsubsection{USGS Regression Equation and Basin Characteristics for Region}

The complete equations used in calculating peak discharge for regions 3,4 , and 5 are presented in Equations 5-1 to 5-9.

Region 3:

$\mathrm{Q} 2=16.2 \mathrm{~A}^{0.894} \mathrm{P}^{0.949}(\mathrm{ST}+1)^{-0.209} \mathrm{E}^{-0.345}$

$\mathrm{Q} 25=112 \mathrm{~A}^{0.793} \mathrm{P}^{0.588}(\mathrm{ST}+1)^{-0.194} \mathrm{E}^{-0.272}$

$\mathrm{Q} 50=147 \mathrm{~A}^{0.778} \mathrm{P}^{0.544}(\mathrm{ST}+1)^{-0.187} \mathrm{E}^{-0.264}$

Region 4:

$\mathrm{Q} 2=3.58 \mathrm{~A}^{0.906} \mathrm{P}^{0.891}(\mathrm{ST}+1)^{-0.331} \mathrm{E}^{-0.125}$

$\mathrm{Q} 25=1,699 \mathrm{~A}^{0.836} \mathrm{P}^{0.917}(\mathrm{ST}+1)^{-0.386} \mathrm{E}^{-0.749}$

$\mathrm{Q} 50=4,323 \mathrm{~A}^{0.824} \mathrm{P}^{0.936}(\mathrm{ST}+1)^{-0.395} \mathrm{E}^{-0.848}$

Region 5:

$\mathrm{Q} 2=418 \mathrm{~A}^{0.911} \mathrm{P}^{1.342}(\mathrm{ST}+1)^{-0.307} \mathrm{E}^{-0.495}(\mathrm{~F}+1)^{-0.605}(\mathrm{~J}+32)^{-0.344}$

$\mathrm{Q} 25=46,460 \mathrm{~A}^{0.866} \mathrm{P}^{1.083}(\mathrm{ST}+1)^{-0.414} \mathrm{E}^{-0.908}(\mathrm{~F}+1)^{-0.560}(\mathrm{~J}+32)^{-0.232}$

$\mathrm{Q} 50=90,720 \mathrm{~A}^{0.860} \mathrm{P}^{1.031}(\mathrm{ST}+1)^{-0.436} \mathrm{E}^{-0.962}(\mathrm{~F}+1)^{-0.546}(\mathrm{~J}+32)^{-0.217}$

Where:

$\mathrm{A}=$ Drainage Area in $\mathrm{mi}^{2}$

$\mathrm{P}=$ Mean Annual Precipitation in inches

ST $=$ Area of Lakes and Ponds in percent

$\mathrm{E}=$ Mean Basin Elevation in feet

$\mathrm{F}=$ Area of Forest in $\mathrm{mi}^{2}$

$\mathrm{J}=$ Minimum Mean January Temperature in $\left({ }^{\circ} \mathrm{F}\right)$

\subsubsection{Python Script Tools for Two Time Period}

A Python script and a tool were developed for use in the calculation of peak discharges in the three flood frequency regions.

For each region, one Python script was created in PythonWin. These scripts were to execute the equations for two-year peak discharge (Q2), twenty five-year peak discharge (Q25), and fifty-year peak discharge (Q50), using the basin characteristics as inputs (see Figures 5-15, 5-16, and 5-17). 


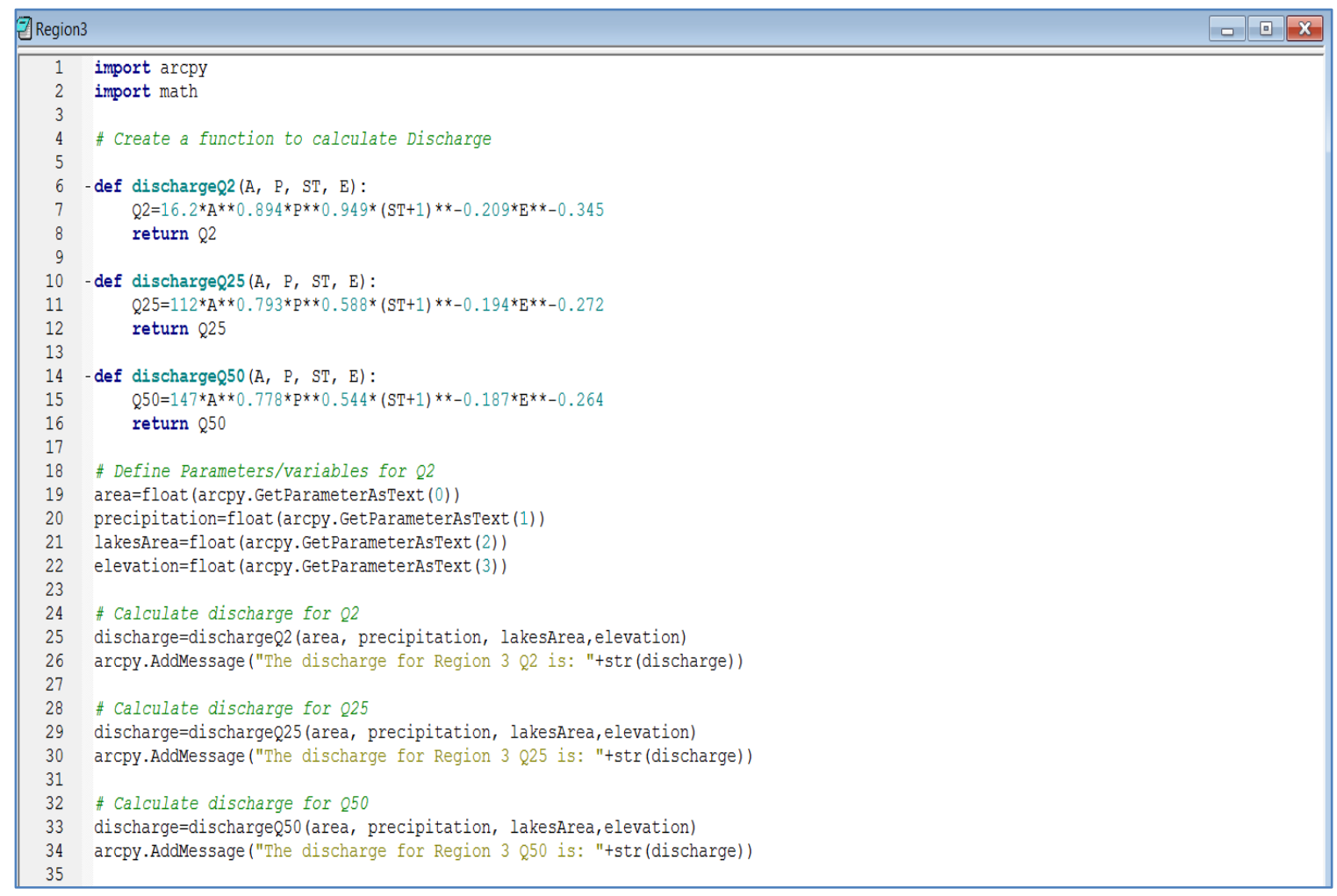

Figure 5-15: Python Script for Region 3 


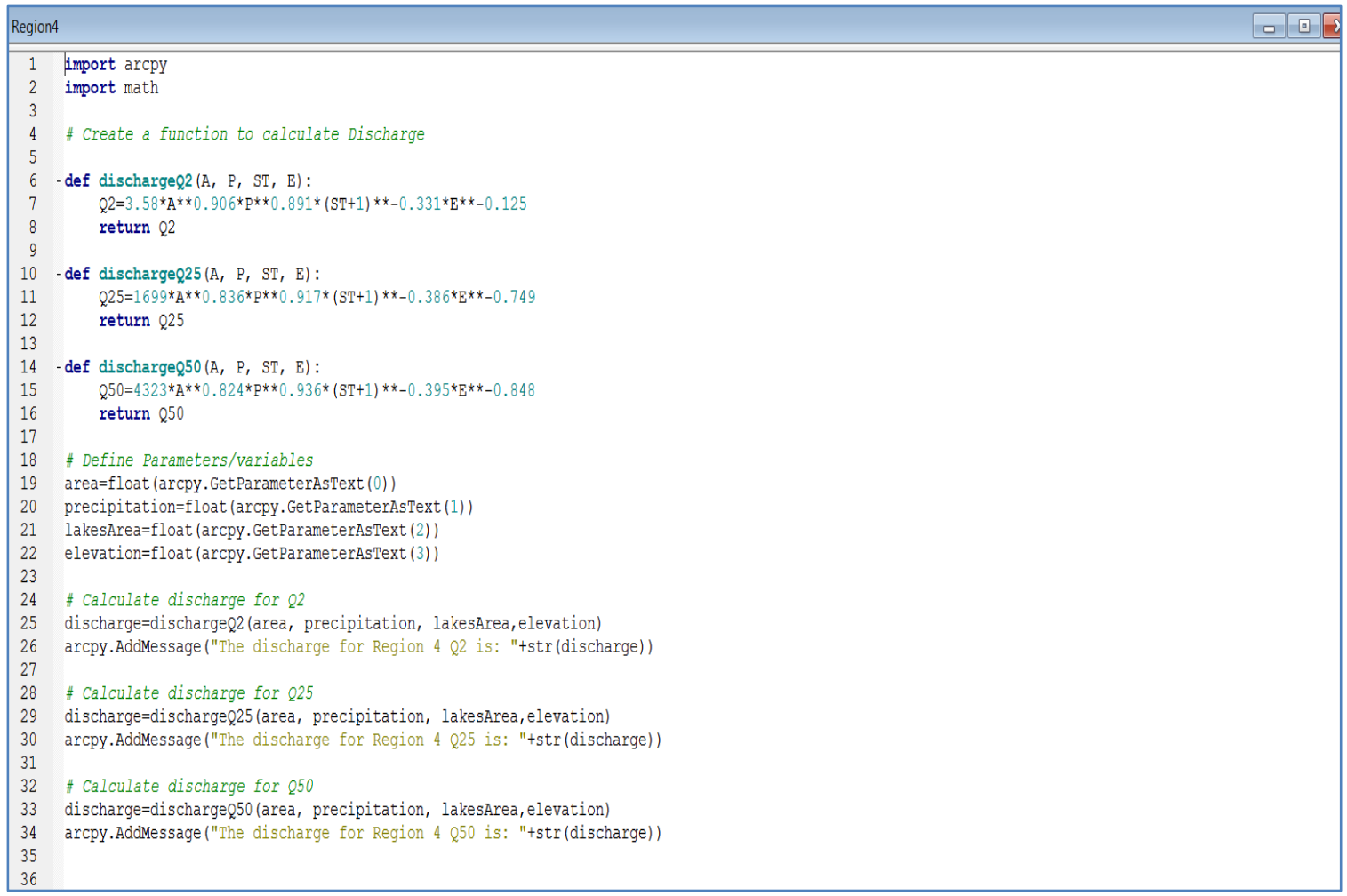

Figure 5-16: Python Script for Region 4

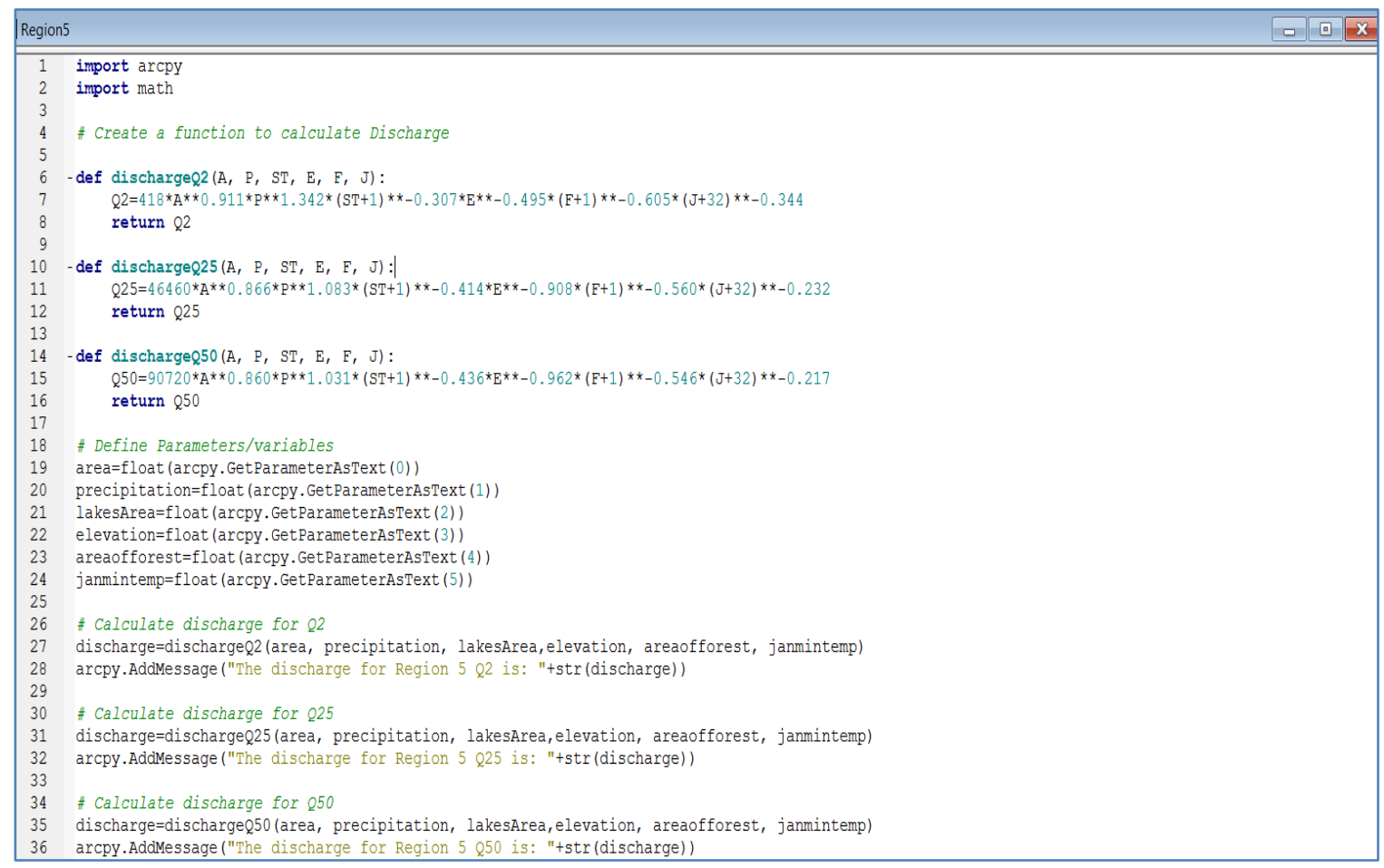

Figure 5-17: Python Script for Region 5 


\subsection{Summary}

This chapter detailed the data processing, calculation of climate differences, and calculation of peak discharge values for the 20th Century and Mid-Century scenarios. 


\section{Chapter 6 - Results and Analysis}

\subsection{Climate Change Scenarios Results}

The differences in climate change scenarios were calculated by subtracting the values of the temperature and precipitation for the $20^{\text {th }}$ Century from the values for the MidCentury. This represented the changes between the two scenarios for the Yukon River Basin. The minimum mean temperature for the $20^{\text {th }}$ Century and Mid-Century is shown in Table 5.

Table 5. Minimum Mean Temperature for the 20th and Mid-Century

\begin{tabular}{|l|l|}
\hline Scenarios & Temperature Minimum $\left({ }^{\circ} \mathrm{F}\right)$ \\
\hline $20^{\text {th }}$ Century & -6.75 \\
& \\
\hline Mid-Century & +3.13 \\
\hline
\end{tabular}

\subsection{Peak Discharge Calculation}

Peak discharges for the three flood frequency return periods were calculated using the USGS equations and the script tool.

\subsubsection{Basin Characteristics Output for USGS Regions}

In order to calculate the total peak discharges for the two scenarios, the basin characteristics for the different regions were required. The values that remain constant are presented in Table 6.

Table 6. Region Characteristics that Remain Constant between Scenarios

\begin{tabular}{|l|l|l|l|}
\hline Basin Characteristic & Region 3 & Region 4 & Region 5 \\
\hline Area of Basin & $149,280 \mathrm{mi}^{2}$ & $11,212 \mathrm{mi}^{2}$ & $170,616 \mathrm{mi}^{2}$ \\
\hline $\begin{array}{l}\text { Area of Lakes and Ponds as } \\
\text { percentage of basin area }\end{array}$ & 0 & $3.25 \%$ & $0.42 \%$ \\
\hline Main Basin Elevation & $1,860 \mathrm{ft}$. & $1,998 \mathrm{ft}$. & $1,183 \mathrm{ft}$. \\
\hline Area Forest & $\mathrm{n} / \mathrm{a}$ & $\mathrm{n} / \mathrm{a}$ & $81,194 \mathrm{mi}^{2}$ \\
\hline
\end{tabular}

Table 7 presents the climate changes between the two periods for precipitation and temperature. The changes are the same for all regions. The difference in precipitation between the two scenarios is 6.0 inches and for temperature it was $9.9\left({ }^{\circ} \mathrm{F}\right)$. Therefore is an increase in the two climate parameters. 
Table 7. Basin Characteristics for 20th and Mid-Century Periods

\begin{tabular}{|l|l|l|l|l|}
\hline & & Region 3 & Region 4 & Region 5 \\
\hline Precipitation & $20^{\text {th }}$ Century & 32.29 inches & 32.29 inches & 32.29 inches \\
\cline { 2 - 5 } & Mid-Century & 38.06 inches & 38 inches & 38 inches \\
\hline \multirow{2}{*}{ Temperature } & $20^{\text {th }}$ Century & $-6.75\left({ }^{\circ} \mathrm{F}\right)$ & $-6.75\left({ }^{\circ} \mathrm{F}\right)$ & $-6.75\left({ }^{\circ} \mathrm{F}\right)$ \\
\cline { 2 - 5 } & Mid-Century & $3.13\left({ }^{\circ} \mathrm{F}\right)$ & $3.13\left({ }^{\circ} \mathrm{F}\right)$ & $3.13\left({ }^{\circ} \mathrm{F}\right)$ \\
\hline
\end{tabular}

\subsubsection{Peak discharge for the Two Time Periods}

The peak discharge values for the Yukon River Basin for the $20^{\text {th }}$ century were calculated with the aid of the script tool created in PythonWin using the basin characteristics and the climate change for the entire basin. The values are presented in tabular, map, and chart formats (Table 8 and Figures 6-1 to 6-4). This therefore indicates that USGS regression equation does not work with large basin area, other possible equations should be developed that will handle basin area for Alaska.

Table 8. Peak Discharge Table for the 20th Century

\begin{tabular}{|c|c|c|c|}
\hline Discharge Years & Region 3 cfs & Region 4 cfs & Region 5 cfs \\
\hline Q2 & $1,377,831$ & 88,492 & 24,671 \\
\hline $\mathbf{Q 2 5}$ & $1,413,272$ & 192,681 & 80,233 \\
\hline $\mathbf{Q 5 0}$ & $1,414,074$ & 217,818 & 101,295 \\
\hline
\end{tabular}

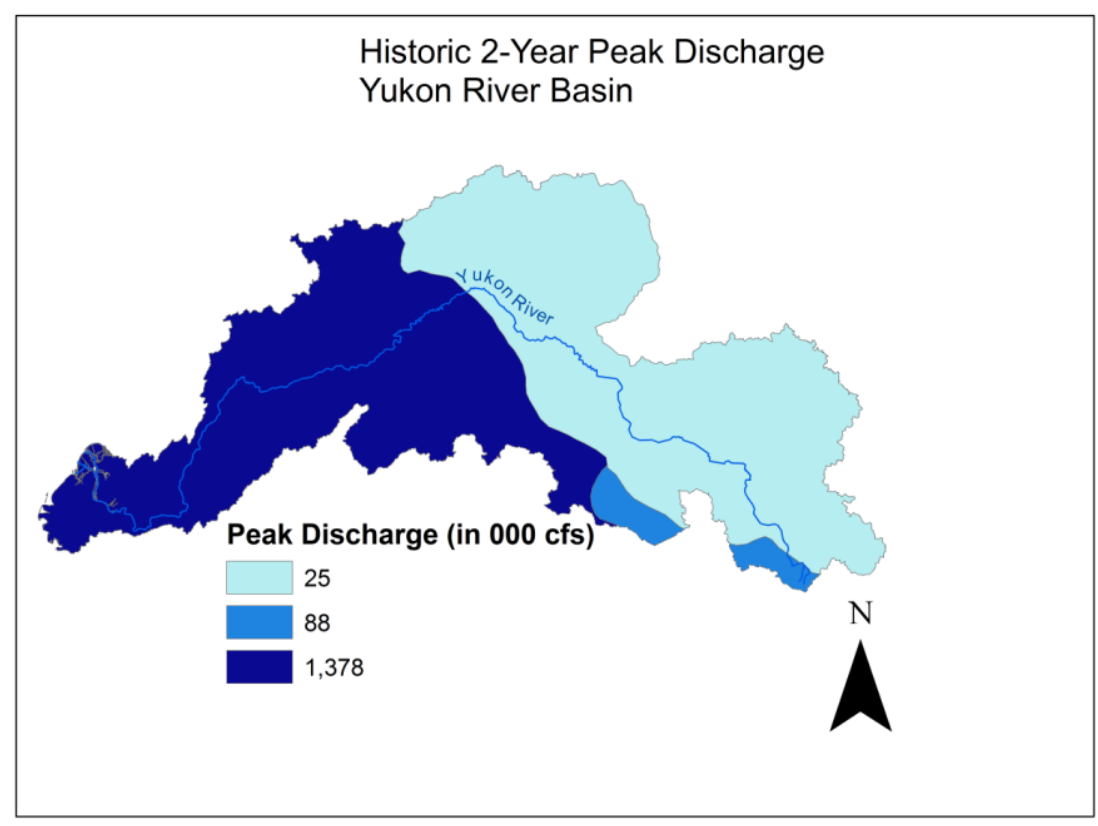

Figure 6-1: 2-Year Historic Peak Discharge 


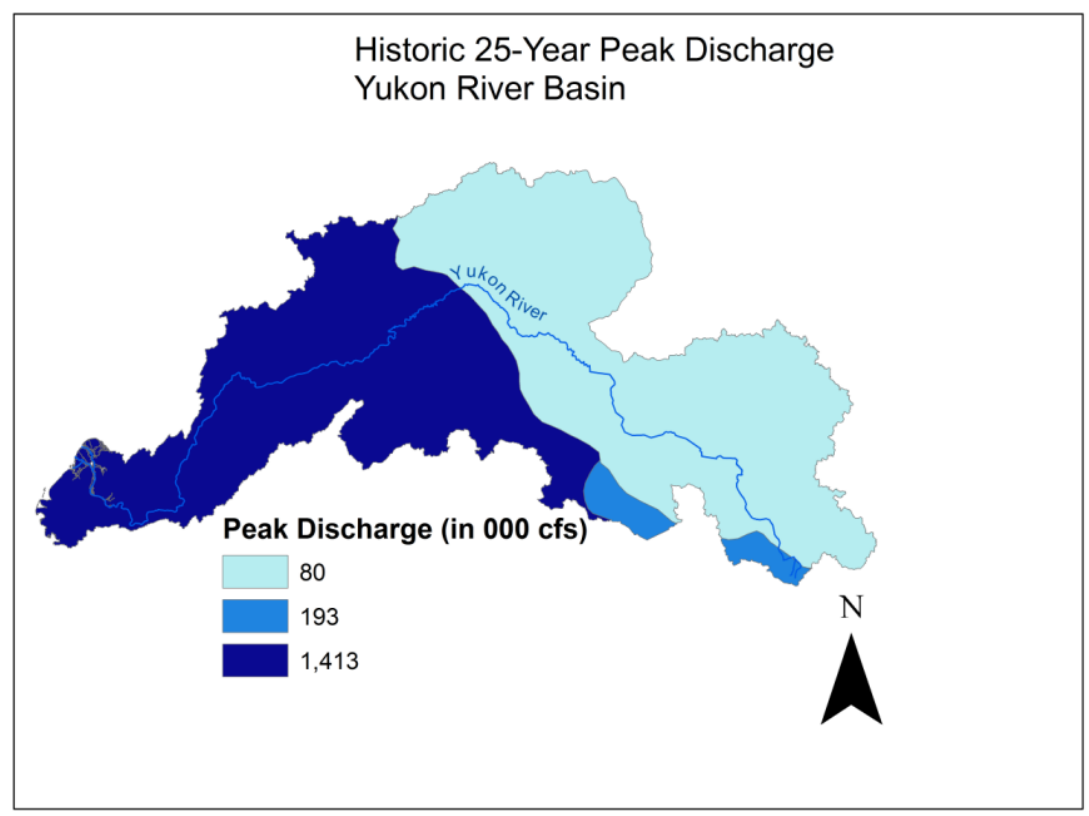

Figure 6-2: 25-Year Historic Peak Discharge

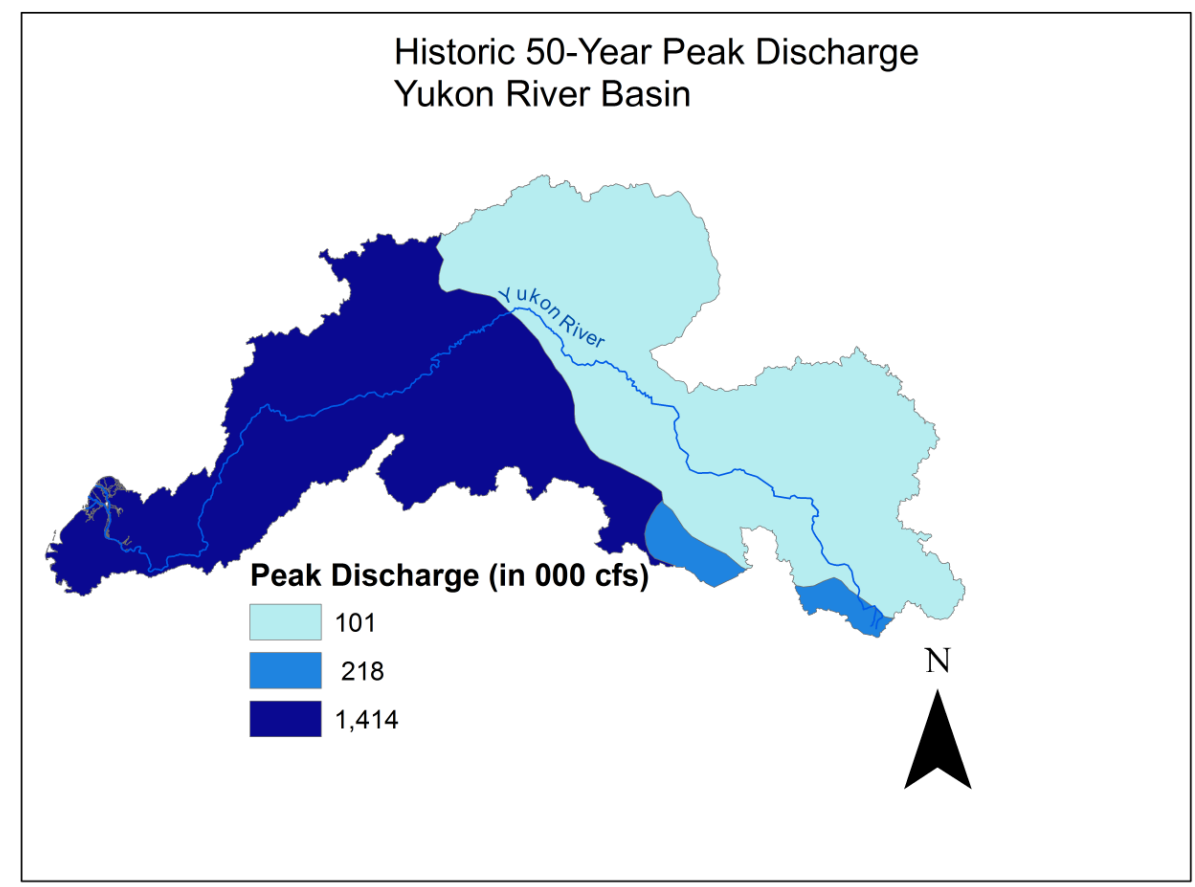

Figure 6-3: 50-Year Historic Peak Discharge 


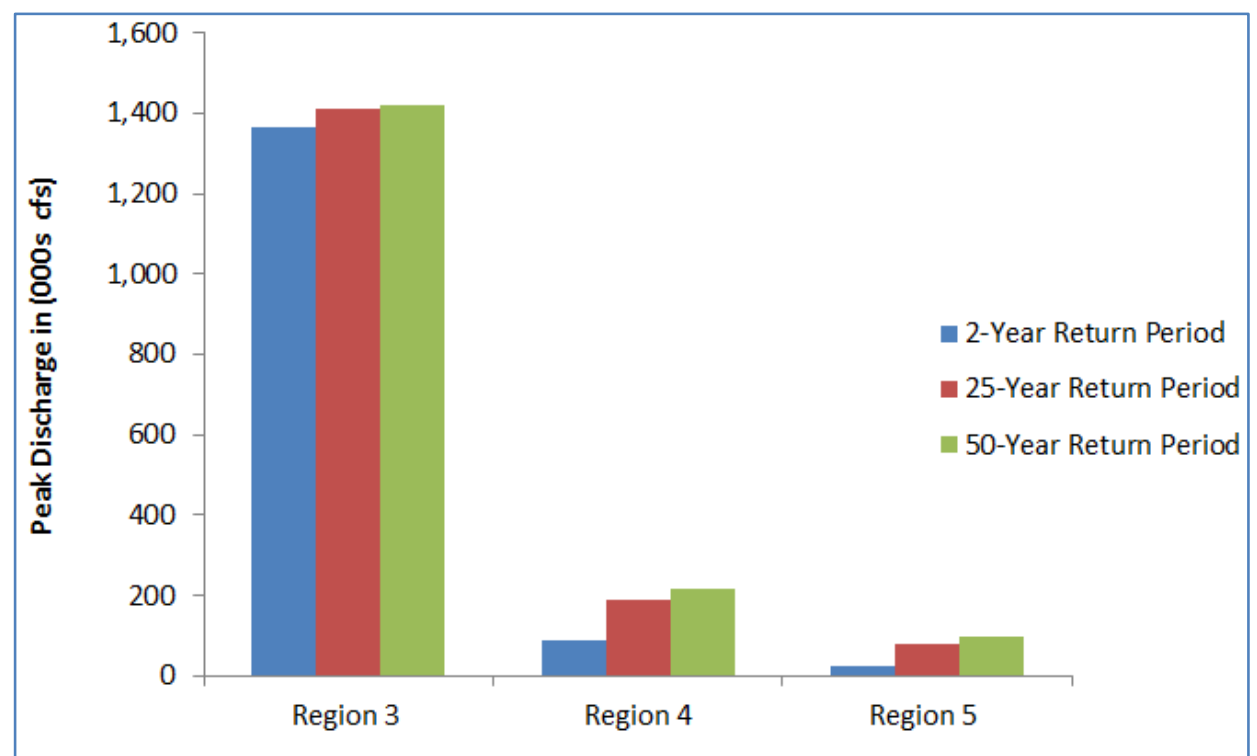

Figure 6-4: Historic Peak Discharge Rates

The peak discharge values for the Yukon River Basin for the Mid-century were calculated with the aid of the script tool created in PythonWin using the basin characteristics, and the climate change for the entire basin. The values are presented in tabular, map, and chart formats (Table 9 and Figures 6-5 to 6-8). The results show an unusual trend in the peak discharge values of region 3 of the Mid-Century period with the Q2 return period greater than the Q25, and the Q25 return period greater than the Q50 return period. It is possible that the USGS equations do not work well with very large basins such as those used in this study. These equations should be investigated before much weight is placed on the results.

Table 9. Peak Discharge for Mid-Century

\begin{tabular}{|c|c|c|c|}
\hline Discharge Years & Region 3 cfs & Region 4 cfs & Region 5 cfs \\
\hline Q2 & $1,610,480$ & 102,552 & 27,459 \\
\hline Q25 & $1,556,716$ & 224,034 & 88,798 \\
\hline Q50 & $1,546,373$ & 254,053 & 111,707 \\
\hline
\end{tabular}




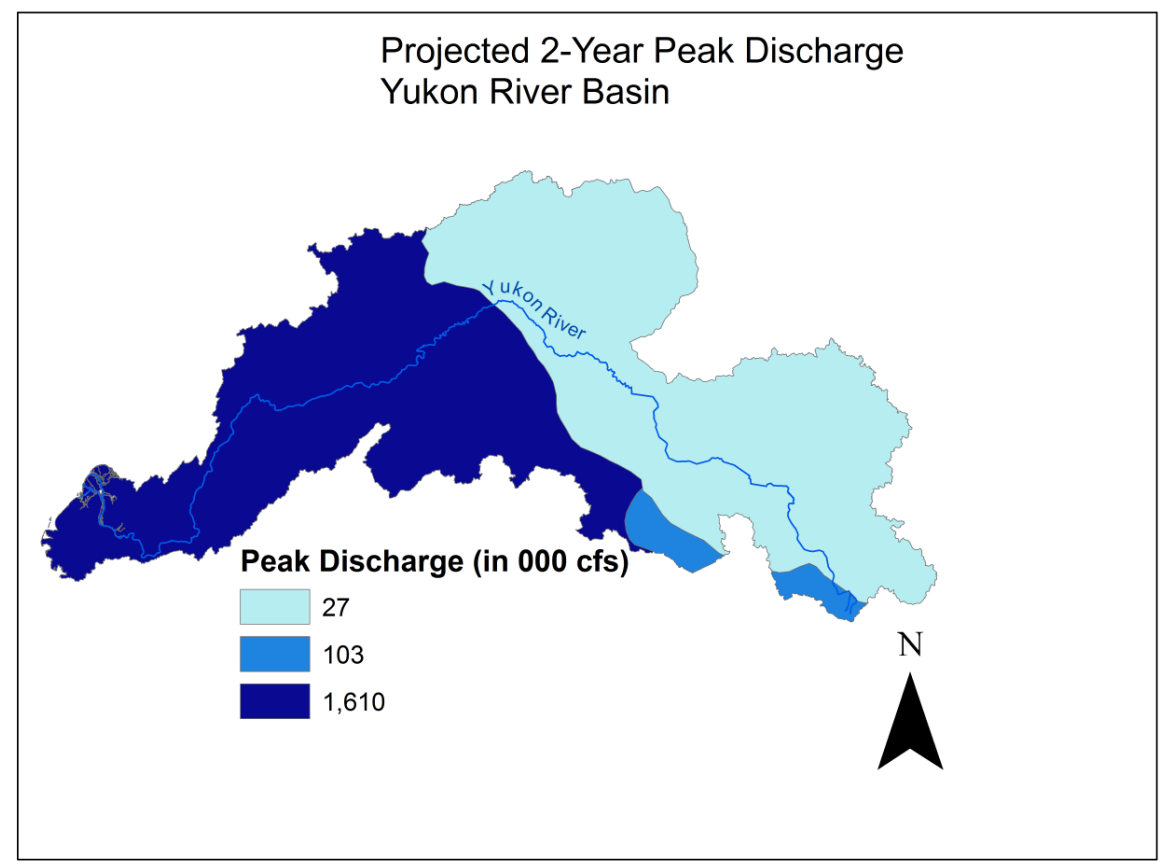

Figure 6-5: 2-Year Project Peak Discharge

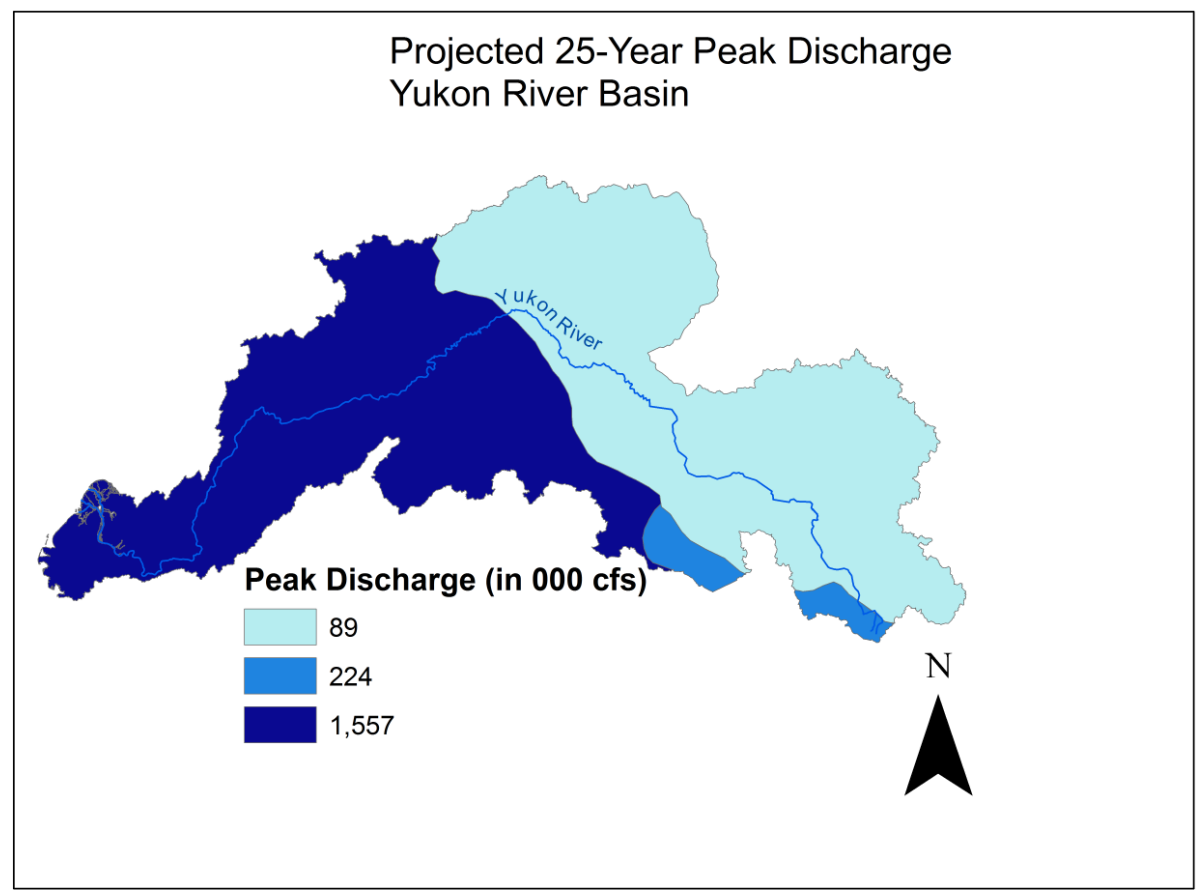

Figure 6-6: 25-Year Project Peak Discharge 


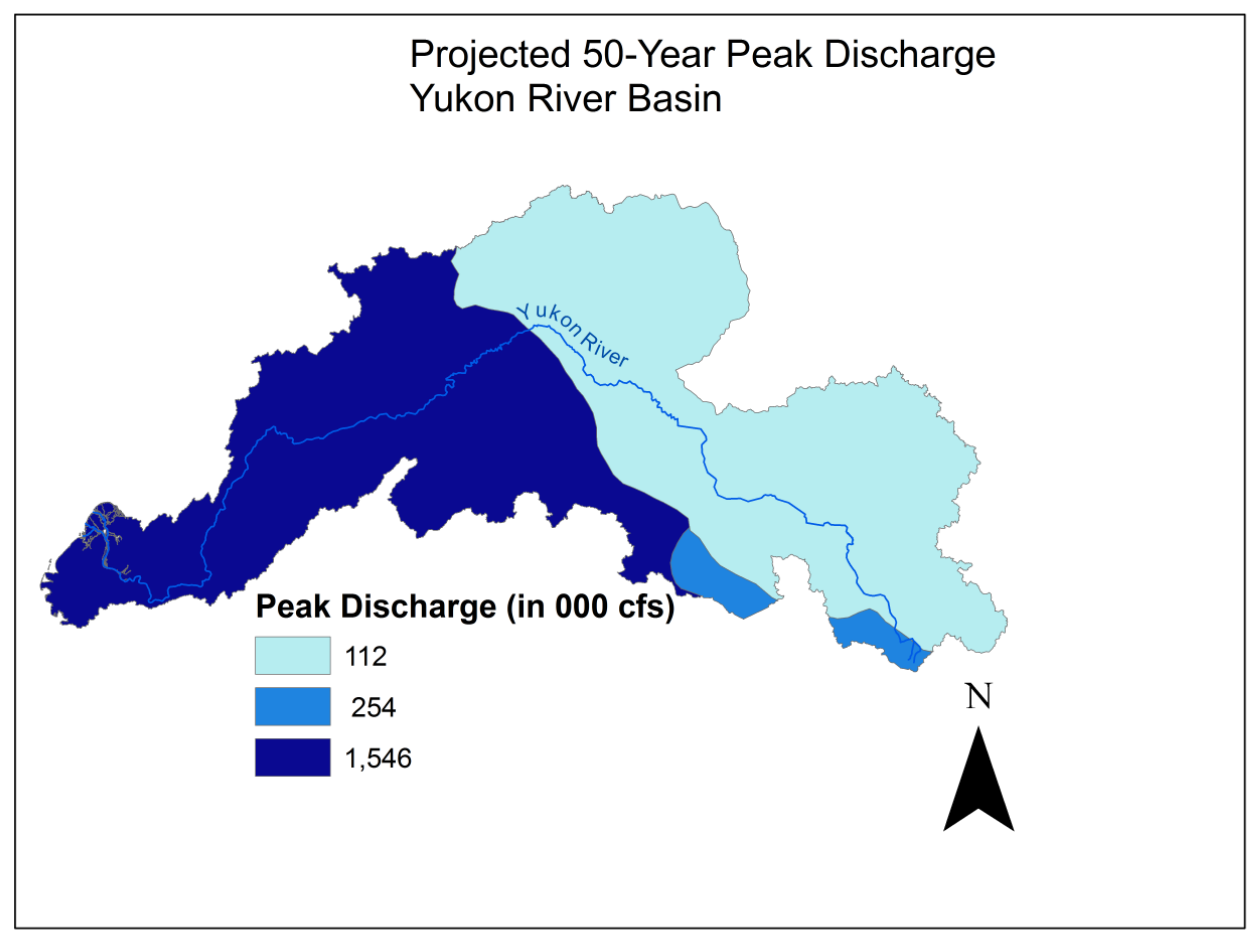

Figure 6-7: 50-Year Project Peak Discharge

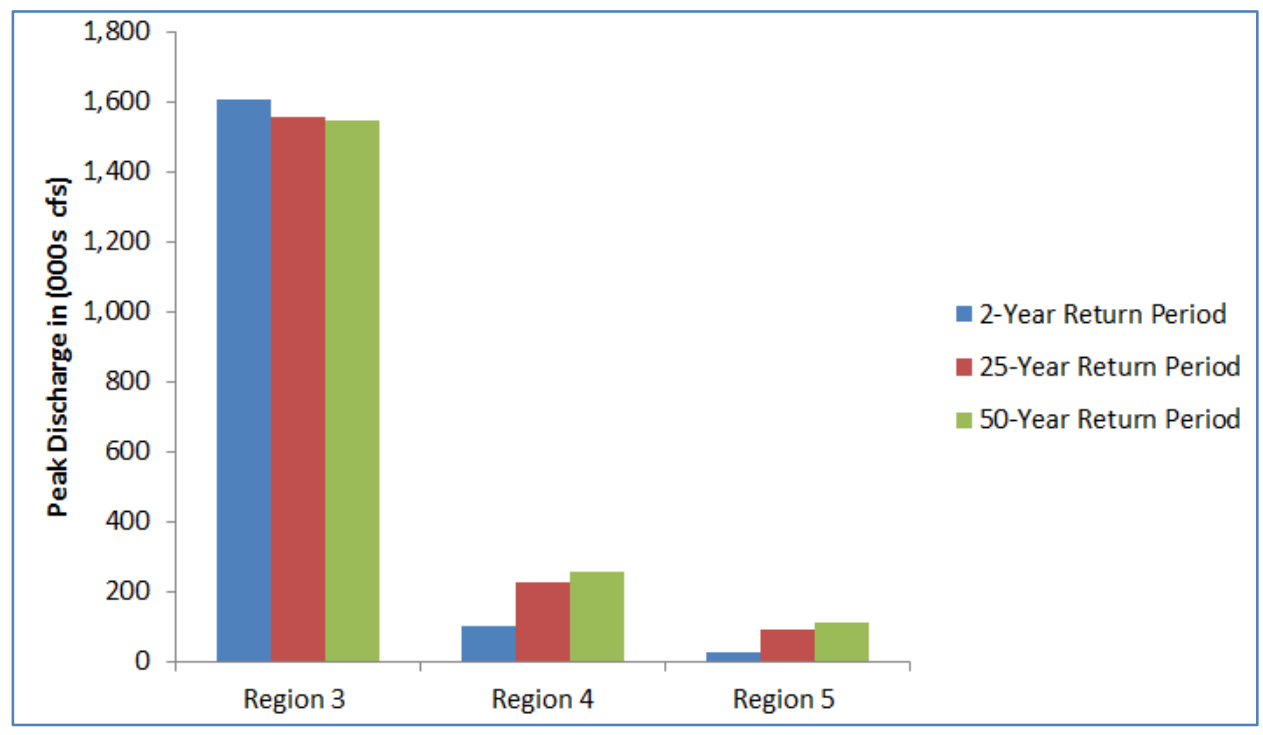

Figure 6-8: Projected Peak Discharge

\subsection{Changes in Peak Discharge between the Two Scenarios}

The peak discharge change over time was determined (see Tables 10 and 11). 
Table 10. Change in Peak Discharge between the Two Time Periods

\begin{tabular}{|l|l|l|l|}
\hline $\begin{array}{l}\text { Flood Frequency } \\
\text { Between Periods }\end{array}$ & Region 3 (cfs) & Region 4 (cfs) & Region 5 (cfs) \\
\hline Q2 & $+232,649$ & $+14,060$ & $+2,788$ \\
\hline Q25 & $+143,444$ & $+31,353$ & $+8,565$ \\
\hline Q50 & $+132,299$ & $+36,235$ & $+10,412$ \\
\hline
\end{tabular}

Table 11. Change in Peak Discharge between the Two Time Periods (\%)

\begin{tabular}{|l|l|l|l|}
\hline $\begin{array}{l}\text { Flood Frequency } \\
\text { Between Periods }\end{array}$ & Region 3(\%) & Region 4 (\%) & Region 5 (\%) \\
\hline Q2 & 16.9 & 15.9 & 11.3 \\
\hline Q25 & 10.1 & 16.3 & 10.6 \\
\hline Q50 & 9.3 & 16.6 & 11.3 \\
\hline
\end{tabular}

For region 3, the two-year flood frequency return period (Q2) increased by $16.9 \%$ between the $20^{\text {th }}$ Century and Mid-Century time periods. The twenty-five and fifty year returns increased by $10.1 \%$ and $9.3 \%$ respectively.

For regions 4 and 5, the return values changed significantly with a normal trend. For example, the volume for the Q2 returns period for region 4, increased by $15.9 \%, \mathrm{Q} 25$ by $16.3 \%$ and Q50 by $16.6 \%$. The Q2 return for region 5 increased by $11.3 \%$, then Q25 by $10.6 \%$, and Q50 by $11.3 \%$ respectively.

\subsection{Summary}

The variations in the flood frequency return periods result from differences in discharge values among the different regions of the basin. This indicates that there were changes in the peak discharges between the two scenarios.

Climate changes between the 20th Century and Mid-Century periods led to significant increase in the peak discharge values. These increases led to significant change in the return flood frequency values between the two time periods. 



\section{Chapter 7 - Conclusions and Future Work}

This chapter provides the conclusion on the assessment of climate change scenarios in the Yukon River Basin. It summarizes the project, taking into consideration preceding chapters, major findings, the project deliverables, future works and suggestions, the conclusion, and summary.

\subsection{Major Findings}

In this project, the Inverse Distance Weighted (IDW) interpolation algorithm was used to create raster datasets from temperature and precipitation point data, as recommended by experts from National Center for Atmospheric Research. IDW created continuous surfaces by using only the geometric characteristics of the temperature and precipitation point observations. The differences in these two datasets indicate the climate change between the 20th Century and the projected Mid-Century periods for the Yukon River Basin. There are also some variations in the peak discharge values in the different regions due to changes in the basin characteristics. There are indications that changes in climate will lead to changes in peak discharge in the Yukon River Basin in the future. The client will use the method in this project and the tool created to closely monitor climate change scenarios and calculate peak discharges within the Yukon River Basin.

\subsection{Project Deliverables}

The project deliverables provided to the client according to the request were: Geodatabase, Python script tool, maps and project documentation, as well as U.S. Geological Survey regression equations and basin characteristics.

\subsection{Future Works and Suggestions}

The project will help the Yukon River Inter-Tribal Watershed Council protect and preserve the Yukon River Basin. It will enable them to visualize the projected climate change and also calculate the projected peak discharge. It would be great for this project to be repeated in five-year intervals. In a future project the differences between the $20^{\text {th }}$ Century period and the end of the $21^{\text {st }}$ Century (2080-2099) could be examined, as this will provide additional information to policy makers to effectively manage the basin in the long term. The soils, land use for all three regions, the area of forest for regions 3 and 4 , should be considered in future projects. This project can be used to motivate future works on climate change and the calculation of peak discharges in the Yukon River Basin.

\subsection{Conclusion}

The main goal of this project was realized. Solutions were provided to the client's problems. The first solution was the creation of a geodatabase, to enable easy visualization and analysis. The second was the calculation of peak discharges, which will 
help to determine flood frequency in the different regions of the Yukon River Basin. To address the third problem, projected climate changes were calculated for the $20^{\text {th }}$ Century and the Mid-Century periods, using ArcGIS and data from the National Center for Atmospheric Research Climate Community System Model.

\subsection{Summary}

The project deliverables met the client requirements, which include: a geodatabase, a script tool, and methods to determine differences between climate change scenarios, maps and project documentation. 


\section{Works Cited}

(IPCC), I. P. (2007). Vital Climate Change Graphic for Latin America and the Carribbean. Corregimiento de Ancon,Panama City, Panama: United Nnations Environmental Program.

Bahremand, A., \& and De Smedt, F. (2008). Distributed Hydrological Modeling and Sensitivity Analysis in Torysa Watershed, Slovakia. Brussels,Belgium: Springer.

Bahremand, A., \& Smedt, F. (2008). Distributed Hydrological Modeling and Sensitivity Analysis in Torysa Watershed, Slovakia. Brussels, Belgium: Springer.

Billings, M. (1847). The frick in early 19th century industrial planning. In I. Overbill (Ed.), What the frick? Frick implementions after the Age of Reason (pp. 45-78). Fargo, ND, USA: Decoder Publishing.

Blogworth, Н. (1978 йил February). Taking back the frack in post-modern spatial analysis. Journal of Well Argued Pointless Arguments, 172(4), 89-103.

Bloomberg. (2012, October 30). news.yahoo.com/blogs. Retrieved from http://news.yahoo.com/blogs/ticket/citing-climate-change-york-bloombergendorese-obama-193913320--election.html

Boehnert, J. (2012). Integration of climate and socio-economic data in GIS. Diversity in climate change science and application workshop (p. 101). Boulder,Colorado: National Center for Atmospheric Research, July 30 - Aug 2, 2012.

Boehnert, J. (2012). Integration of Climate and Socio-Economic Data in GIS Workbook. Enhancing Diversity in Climate Change Science and Application Workshop. Boulder, Colorado: National Center for Atmospheric Research, July 30 - Aug 2, 2012.

Boville, B. A., \& Gent, P. R. (1998). The NCAR Climate System Model, Version One. American Meteorology Society, 11, Issue 6, 1115-1130.

Braggington, Е. (2009 йил 13-April). Frickin' useless. Retrieved 2009 йил 3-May from Orifice generated thoughts:

www.orificeInterface.com/Frickin_Frack/20090412.htm

Byron A.Boville and Peter R.Gent. (1998). The NCAR climate system model, version one. American Meteology Society, 1115-1130.

Collins, W. D., Bitz, C. M., Blackmon, M. L., Bonan, G. B., Bretherton, C. S., Carton, J. A., et al. (2005). The Community Climate System Model Version 3 (CCSM3). Journal of Climate, 2122-2143.

Council, Y. R.-T. (2005, November 1). Yukon River Watershed Tribal Environmental Success.

Curran, J. H., Meyer, D. F., \& Tasker, G. D. (2003). Estimating the Magnitude and Frequency of Peak Streamflows for Ungaged Sites on Streams in Alaska and Conterminuous Basins in Canada. Anchorage, Alaska: U.S. Geological Survey Water Resources Investigations Report 03-4188, 101p.

Dale, V. H. ( 1997). The Relationship Between Land-Use Change and Climate Change. The Ecological Society of America, vol.7(3), pp.753-769.

Dale, V. H. (August 1997). The Relationship Between Land-Use Change and Climate Change. The Ecological Society of America, vol.7(3), pp.753-769.

Dangermond, J., \& Artz, M. (2010, June 1). Climate Change is a Geographic Problem: The Geographic Approach to Climate Change. Redlands: Esri. 
Edwards, P. N. (2010). A Vast Machine: Computer Models, Climate Data, and the Politics of Global Warming. Massachusetts: The Massachusetts Institute of Technology Press.

Giorgi, F. (2005). Climate change Prediction. Climate change(2005)73, pp. 239-265. Giorgi, F. (2005). Climate Change Prediction. Climate Change, 73, pp. 239-265.

Hay, L. E., \& Gregory, J. M. (2010, April 16). Hydrological Effects of Climate Change in the Yukon River Basin. Climate Change, pp. 509-523.

IPCC. (2007). Vital Climate Change Graphic for Latin America and the Caribbean. Corregimiento de Ancon, Panama City, Panama: United Nations Environmental Program.

Jack Dangermond and Matt Artz. (2010, June 1). Climate change is a geographic problem. The geographical approach to climate change, pp. 1-33.

Janet H. Curran, David F. Meyer, and Gary D. Tasker. (2003). Estimating the Magnitude and Frquency of Peak Streamflows for Ungaged Sites on Streams in Alaska and Conterminuous Basins in Canada. Anchorage, Alaska: U.S. Geological Survey Water-Resources Investigations Report 03-4188, 101p.

Jeffrey T.Kiehl and Peter R.Gent. (2004). The community climate system model,version 2. Journal of Climate, 3666-3682.

Jones, J. (1999). Climate Change and Sustainable Water Resources: Placing the Threat of Global Warming in Perspective. Hydrological Science Journal, 44:4, 541-557.

Jones, J. (1999). Climate change and sustainable water resources:placing the threat of global warming in perspective. Hydrological Science Journal, 541-557.

Jones, S. H., \& Fahl, C. B. (1994). Magnitude and Frequency of Floods in Alaska and Conterminous Basins of Canada. Anchorage, Alaska: U.S. Geological Survey Water-Resources Investigation Report 93-4179.

Kiehl, J. T., \& Gent, P. R. (2004). The Community Climate System Model, version 2. Journal of Climate, 9, 3666-3682.

Knox, O. (2012, October 30). news.yahoo.com/blogs. Retrieved October 30, 2012, from news.yahoo.com/blogs: http://news.yahoo.com/blogs/ticket/citing-climatechange-york-bloomberg-endorses-obama-193913320--election.html

Lapp, S., Bryne, J., \& and Kienzle, S. (2005). Climate Warming Impacts on Snowpack Accumulation in an Alpine Watershed. International Journal of Climatology, vol.25, pp.521-536.

Lapp, S., Bryne, J., Townshend, \& Kienzle, S. (2005). Climate Warming Impacts on Snowpack Accumulation in an Alpine Watershed. International Journal of Climatology, 25, pp. 521-536.

Lin, Y.-P., Hong, N.-M., Wu, P.-J., Wu, C.-F., \& Verburg. (2007). Impacts of Land Use Change Scenarios on Hydrology and Land Use Patterns in the Wu-Tu Watershed in Northern Taiwan. Landscape and Urban Planning, 80, pp. 111-126.

Lui, D. L., Mo, J., Fairweather, H., \& and Timbal, B. (13 - 17 July 2009). A GIS Tool to Evaluate Climate Change Impact: Functionality and Case Study. 18th World IMACS/MODSIM Congress (pp. 1936 - 1942). Cairns, Australia: Mssanz.

Lui, D. L., Mo, J., Fairweather, H., \& and Timbal, B. (13 - 17 July 2009). A GIS Tool to Evaluate Climate Change Impact: Functionality and Case Study. 18th World IMACS/MODSIM Congress (pp. 1936 - 1942). cains, Australia: Modisim09. 
McCube, L. E. (2010, April 16). Hydrological effects of climate change in the Yukon River Basin. climate change(2010), pp. 509-523.

Neelin, J. (2011). Climate Change and Climate Modelling. New York: Cambridge University Press.

Neelin, J. (2011). Climate Chnage and Climate Modelling. New York: Cambridge University Press.

Nordhaus, W. D. (1994, October 1). Managing the global commons. The economics of climate change, p. 223.

Nordhaus, W. D. (1994, October 1). Managing the Global Commons. The Economics of Climate Change, p. 223.

Paul F. Schuster, Maracle Karonhiakta'tie Bryan and Herman-Mercer Nicole. (2010). Water quality in the Yukon River Basin, water years 2006-2008. U.S.Geological Survey no.2010-1241, 220pp.

Schuster, P., \& and Maracle, K. (2010). Studies of climate change in the Yukon River Basin-Connecting community and science through a unique partnership. U.S. Geological Survey Fact Sheet 2010-3020, pp. 4.

Schuster, P., Bryan, M. K., \& Nicole, H. M. (2010). Studies of Climate Change in the Yukon River Basin Connecting community and science through a unique partnership. U.S Geological Survey Fact Sheet 2010-3020, pp. 4.

Schuster, Paul F; Bryan, Maracle Karonhiakta'tie; Nicole, Herman-Mercer. (2010). Water Quality in the Yukon River Basin, Water Years 2006-2008. Alaska: U.S. Geological Survey no. 2010-1241, 220pp.

Services PR, L. (1997, January 1). PR Services Ltd. Retrieved October 31, 2012, from PR Services Ltd. Web site: http://yukoninfo.com/yukonriver/

Stanley H.Jones and Charles B.Fahl. (1994). Magnitude and Frequency of Floods in Alaska and Conterminous Basins of Canada. Anchorage, Alaska: U.S.Geological Survey Water-Resources Investigation Report 93-4179.

Tomer, M., \& and Schilling, K. (2009). A Simple Approach to Distinguished Land-Use and Climate Changes Effects on Watershed Hydrology. Journal of Hydrology, vol.376, pp.24-33.

Tomer, M., \& Schilling, K. (2009). A Simple Approach to Distinguished Land-Use and Climate Change Effects on Watershed Hydrology. Journal of Hydrology, vol.376, pp.24-33.

Willian D. Collins,Cecilia M.Bitz,Maurice L.Blackmon,Gordon B.Bonan,Christopher S.Bretherton,James A.Carton,Ping Chnag,Scott C.Doney,James J.Hack, Thomas B.Henderson,Jeffrey T.Kiehl,William G.Large,Daniel S. McKenna,Benjamin D.Santer and Richard D.Smith. (2005). The community climate system model version 3 (CCSM3). Journal of Climate, 2122-2143.

YRITWC. (2005, November 1). Yukon River Watershed Tribal Environmental Success. Yu_Pin, L., Nien-Ming, H., Pei-Jung, W., Chen-Fa, W., \& and Verburg, P. H. (2007). Impact of Land Use Change Scenarios on Hydrology and Land Use Patterns in the Wu-Tu Watershed in Northern Taiwan. Wageningen, The Netherlands: Elsevier.

Yu_Pin, L., Nien-Ming, H., Pei-Jung, W., Chen-Fa, W., \& and Verburg, P. H. (2007). Impact of Land Use Chnage Scenarios on Hydrology and Land Use Patterns in 
the Wu-Tu Watershed in Nothern Taiwan. Wageningen,The Netherlands: Elsevier. 


\section{Appendix A. Climate Change Maps and Charts}

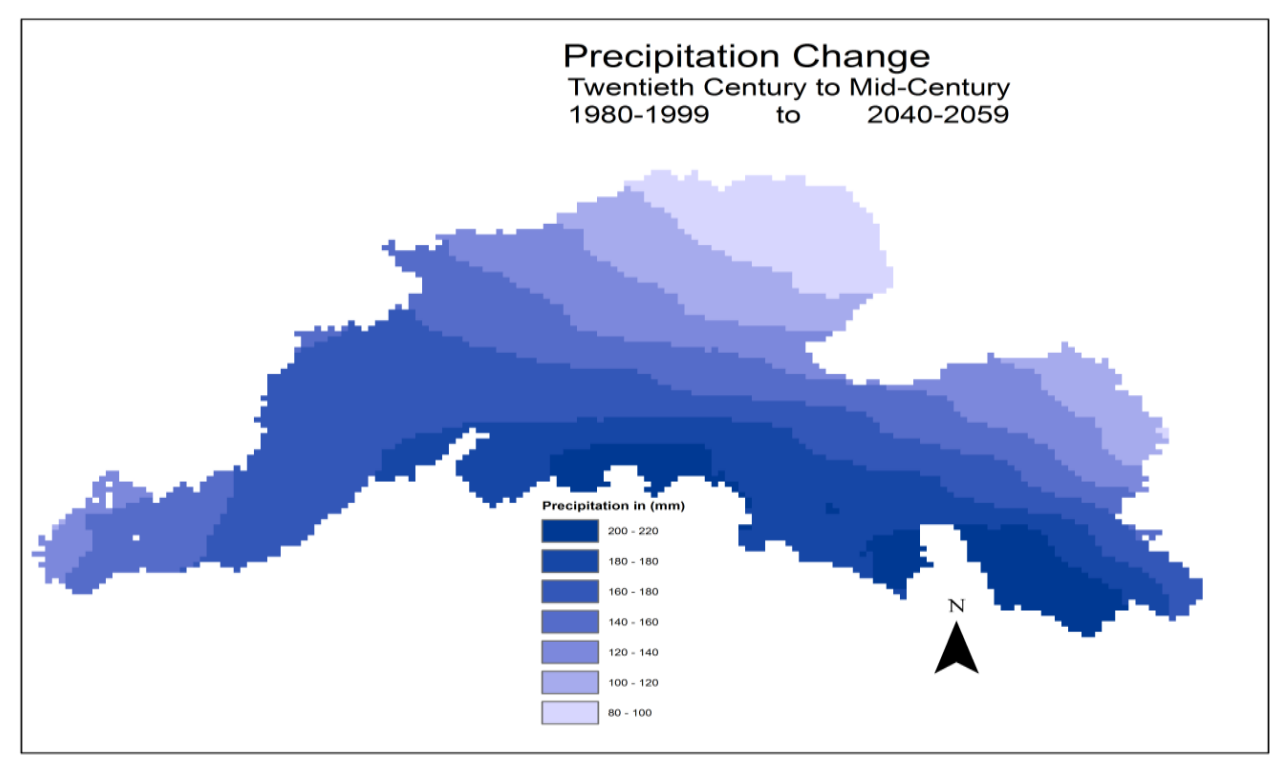

A: Precipitation Change for $20^{\text {th }}$ Century and Mid-Century

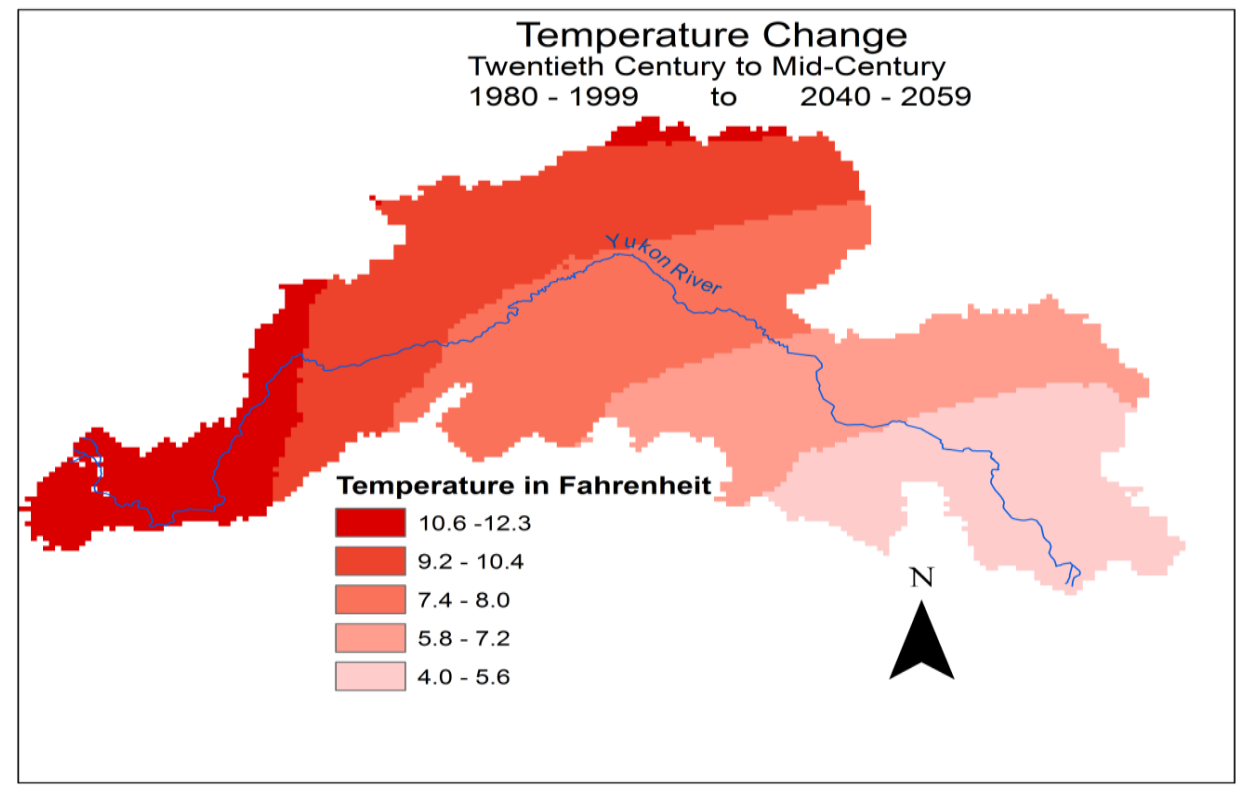

B: Temperature Change for $20^{\text {th }}$ Century and Mid-Century 

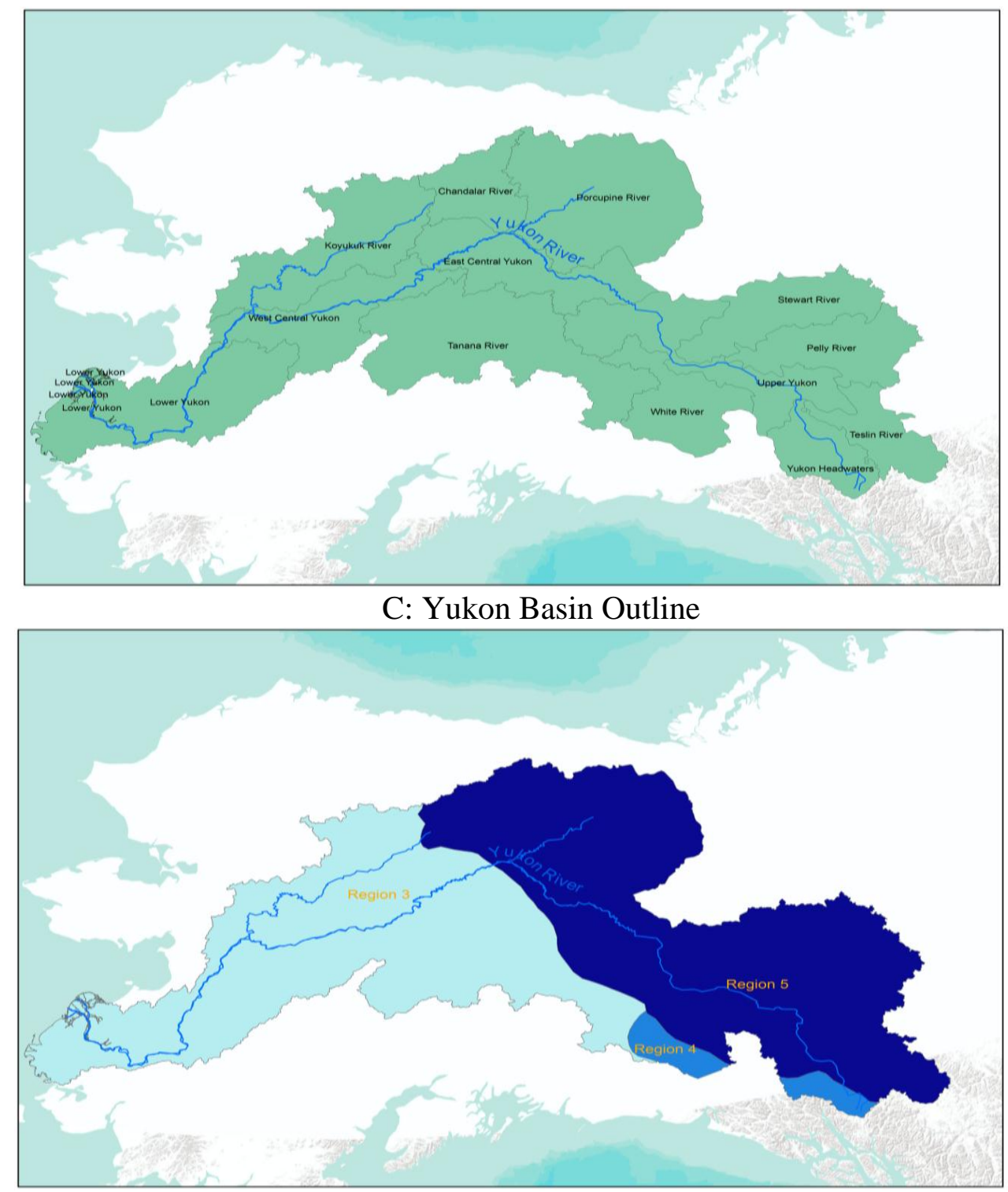

D: United States Geological Survey Regions 


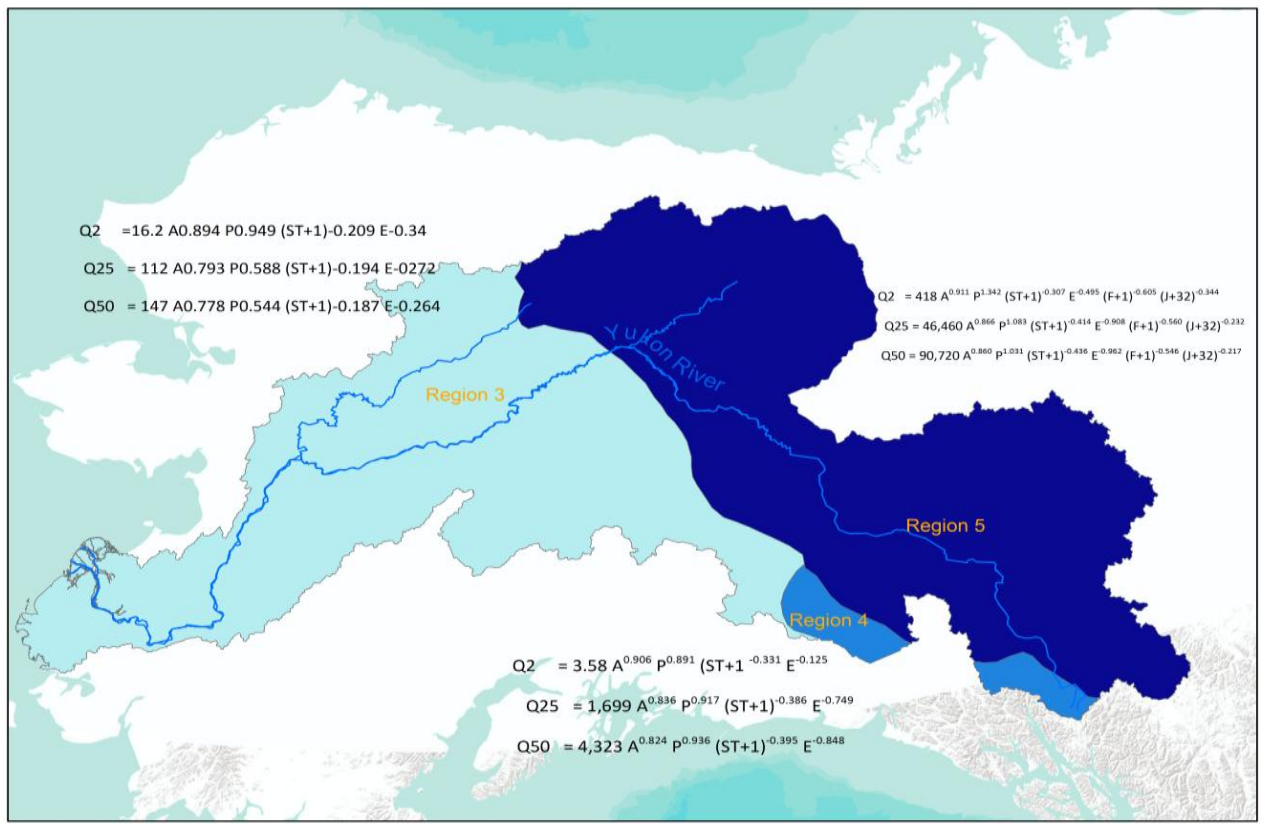

E: United States Geological Survey Regression Equations for Yukon River Basin. 


\section{Appendix B: Peak Discharge}

\section{Script Tool for the $20^{\text {th }}$ Century and Mid-Century Periods}

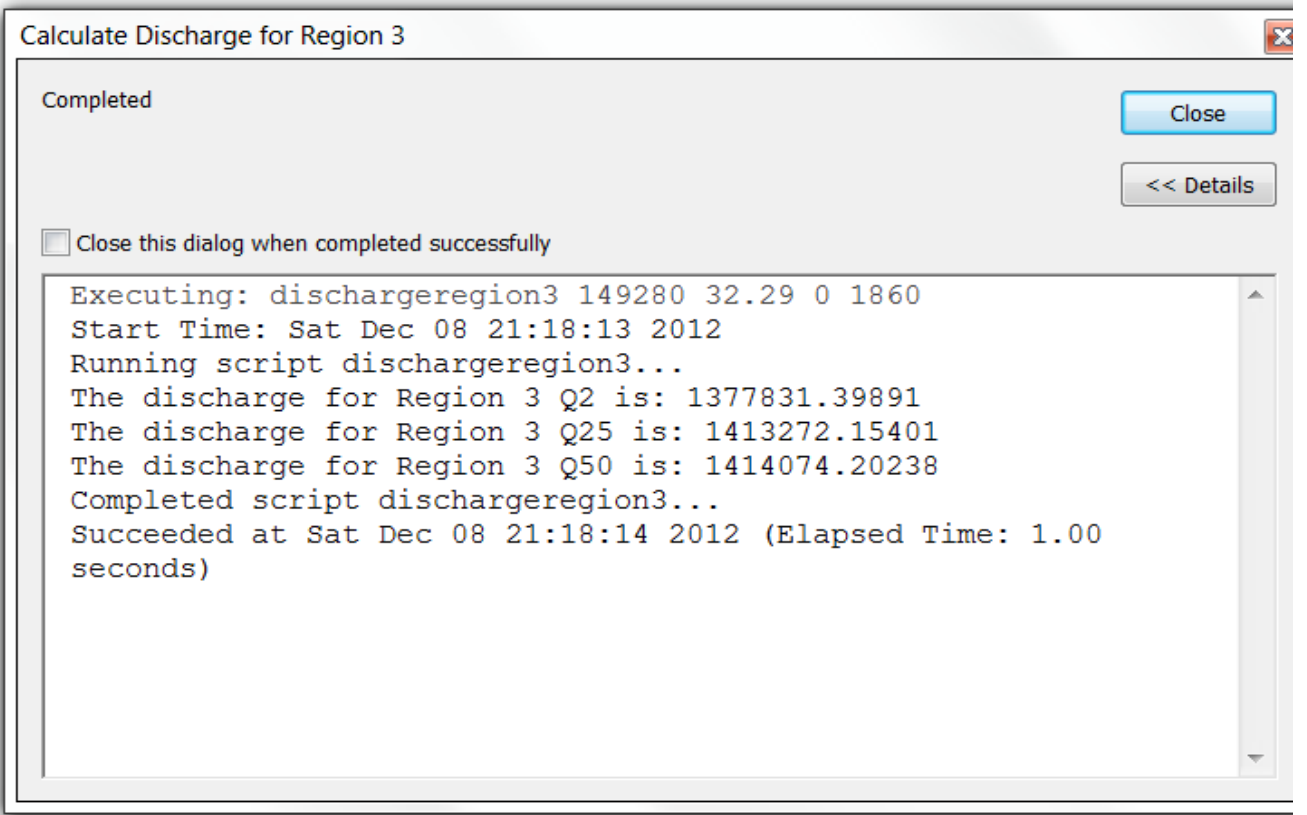

Historic Peak Discharge for Region 3

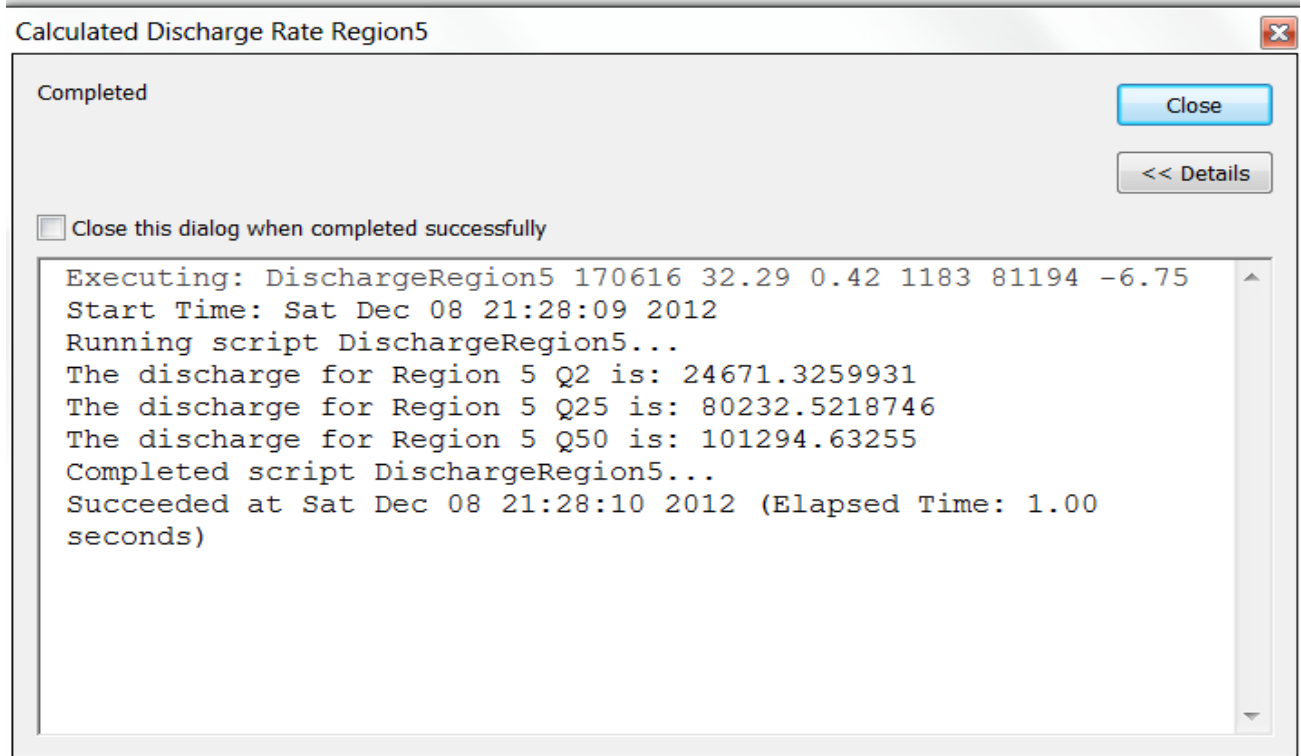

Historic Peak Discharge for Region 4 


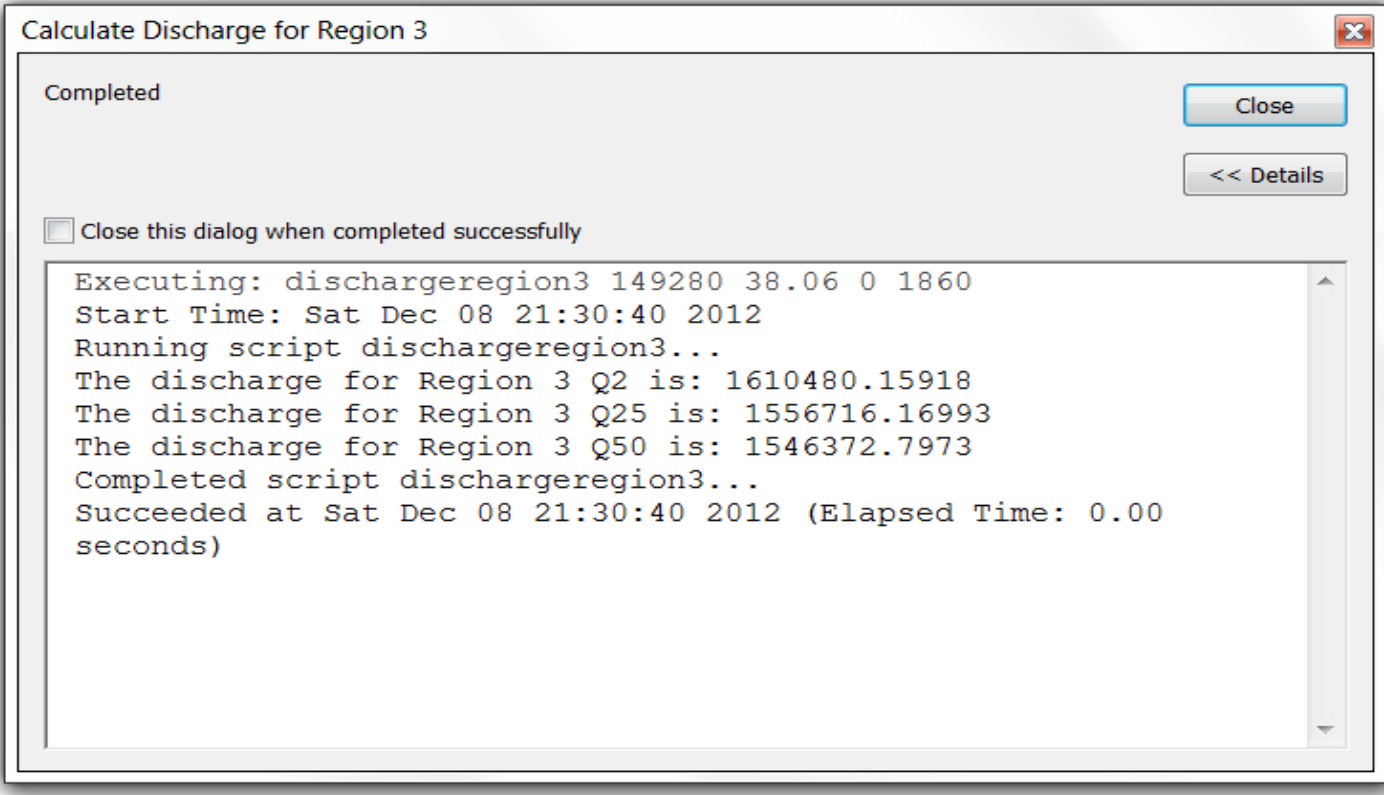

Historic Peak Discharge for Region 5

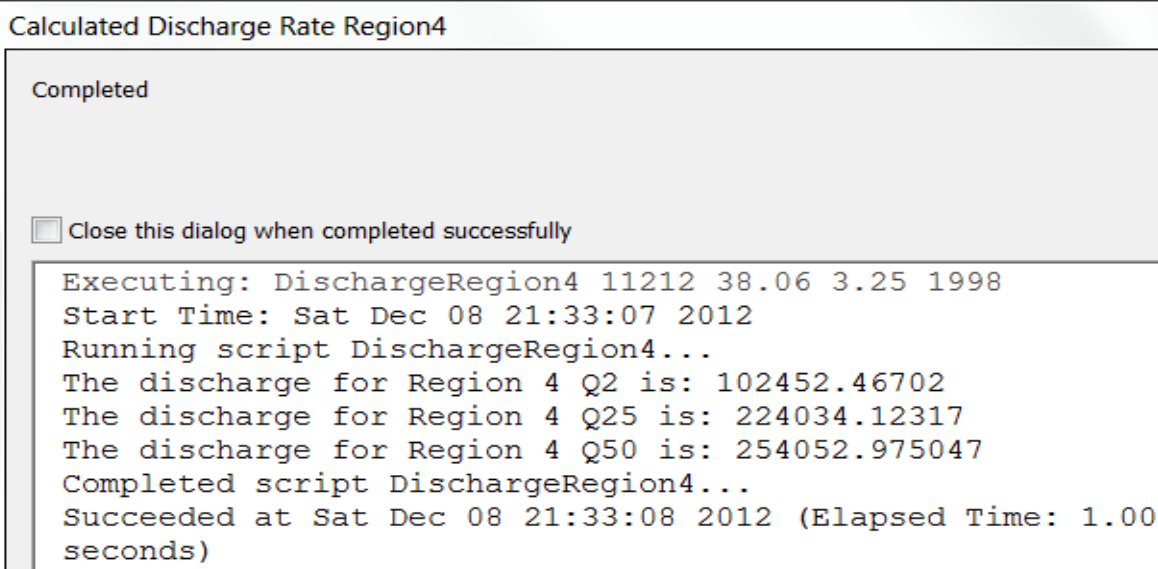

Completed

$\square$ Close this dialog when completed successfully

Executing: DischargeRegion4 $11212 \quad 38.06 \quad 3.251998$

Start Time: Sat Dec 08 21:33:07 2012

Running script DischargeRegion4...

The discharge for Region 4 Q2 is: 102452.46702

The discharge for Region 4 o25 is: 224034.12317

The discharge for Region 4 Q50 is: 254052.975047

Completed script DischargeRegion 4 ...

Succeeded at Sat Dec 08 21:33:08 2012 (Elapsed Time: 1.00

seconds)

\section{Projected Peak Discharge for Region 3}




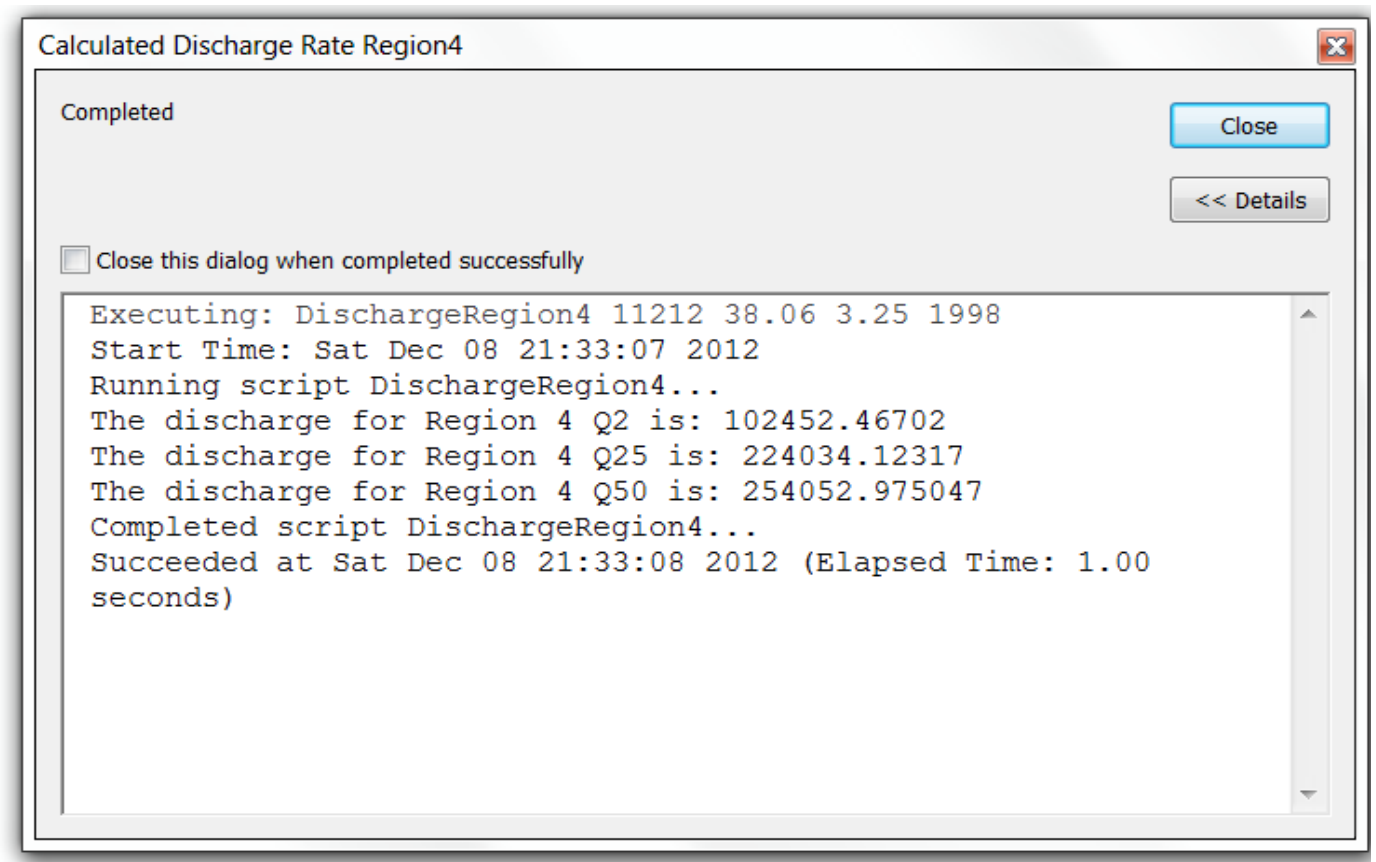

Projected Peak Discharge for Region 4

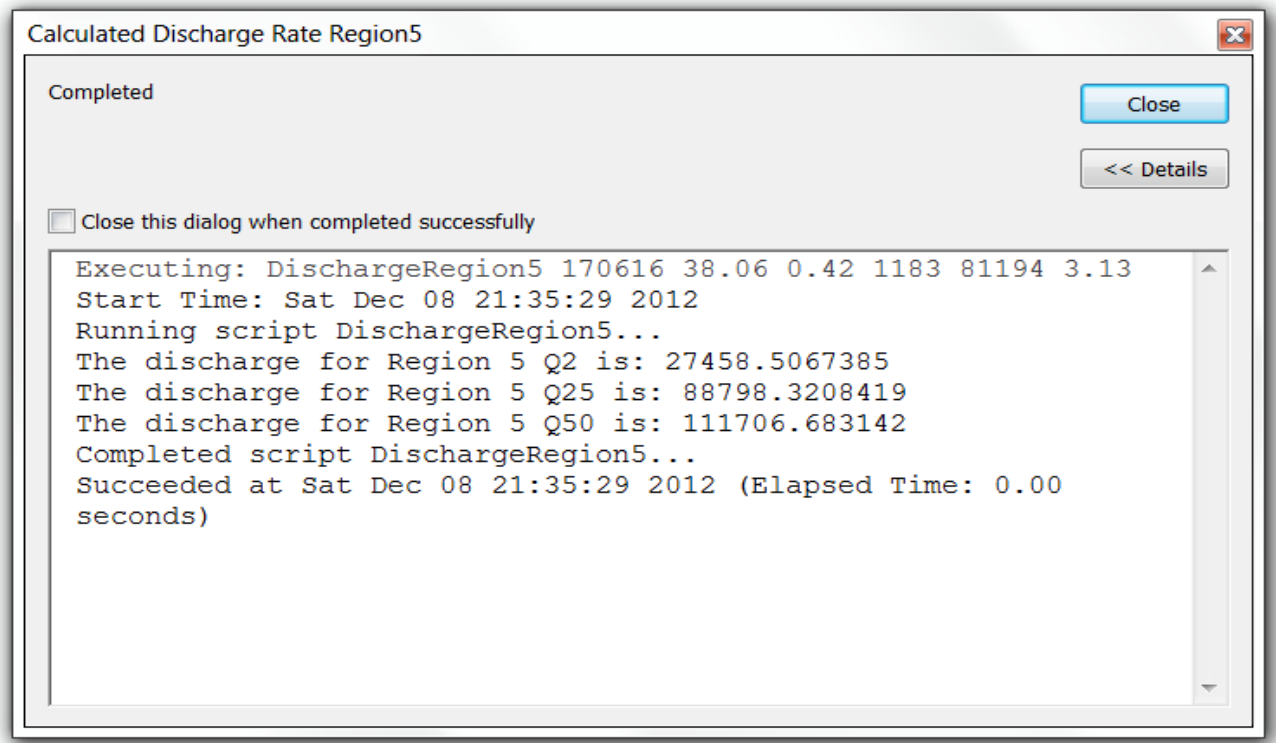

Projected Peak Discharge for Region 5

\section{Appendix C: Forest Data preparation}

\section{Download}

http://www.cec.org/Page.asp?PageID=924\&ContentID=2819\&AA_SiteLanguageID=1 2. Project: Layer properties-

Query Builder Expression: class Name $=$ Mixed Forest or class Name $=$ deciduous or class Name $=$ Taiga or

3. Extract by mask 
4. Convert raster to polygon

5. Aggregate polygon on region 5 alone

That select by attribute: Region 5 .

\section{Appendix D: Instruction Manual}

- Download Temperature (TAS) and Precipitation data from National Center for Atmospheric Research (NCAR):http://gisclimatechange.ucar.edu. Contact the site administrator who will grant access to the website.

- The datasets was derived from a global climate model output. It contains information for each cell about change in annual mean temperature from the present day climate (1980-1999) to the Mid-Century (2040-2059) climate, as projected by High A2 scenario. The dataset came from the climate change scenario portal (http:www.GISClimateChangeiucar.edu).

- Project the data to area of interest projected coordinate system, for the Yukon River Basin project NAD_1927_Alaska_Albers_Meters was used.

- Join the temperature layers for the $20^{\text {th }}$ Century and Mid-Century Scenarios in one attribute table, and do same with precipitation. This will provide access to find the differences in precipitation for the two difference scenarios using Field Calculator. Field Calculation - procedures

- Temp: Convert from Kelvin to Fahrenheit $(\mathrm{F} 1-273.15) * 1.8+32$

Prep: $\mathrm{mm}$ to Inches $\mathrm{F} 1 * 0.0393701$

- Interpolate the temperature and precipitation data to make sure that the data points are correct for the purpose of the project with exact representation. The Inverse Distance Weighted (IDW) interpolation is recommended.

- Clip the data to the study area, using extract by mask from the ArcGIS Toolbox.

- Find the range in temperature and precipitation between the two scenarios; this will give the actual change.

Tool Documenting

1. PythonWin should be downloaded online

2. To get access to the Python script created, On your PC go to start then type Python on display dialog, you will see PythonWin, IDLE Python and IDLE Python, click Python win then a Python dialog will open.

3. Go to file, then select open, navigate to your folder on c: MIP Final/MIP Scripts and click any one of the scripts: Region 3, Region 4, and Region 5. For example click and open Region 3 script, it will open showing the equations and Basin Characteristics for the two-year return period, twenty-five year return period, and fifty -year returns (Q2, Q25 and Q50).

4. These scripts are modifiable and can be used in the future to calculate the peak discharge for different return periods in the Yukon River Basin. 
5. For example the peak discharge can be calculated for Q5, Q10, Q100, Q200, and Q500, by replacing, the values of the Basin Characteristics and equations in the Python script, as indicated in step 3 above.

6. To run the Tool, open ArcMap, then ArcCatalog, navigate to the Climate Change Discharge geodatabase. Open the Discharge Calculation Toolbox. Right click the Tool Calculated Discharge for Region 3 or 4 or 5 . Then click to open to open the Tool dialog which will appear as shown below. Then you should manually enter the basin Characteristics values for the region for example here is region 4, dialog box, then click OK. It will run and a display message dialog with the discharge values for Q2, Q25 and Q50. See Appendix B.

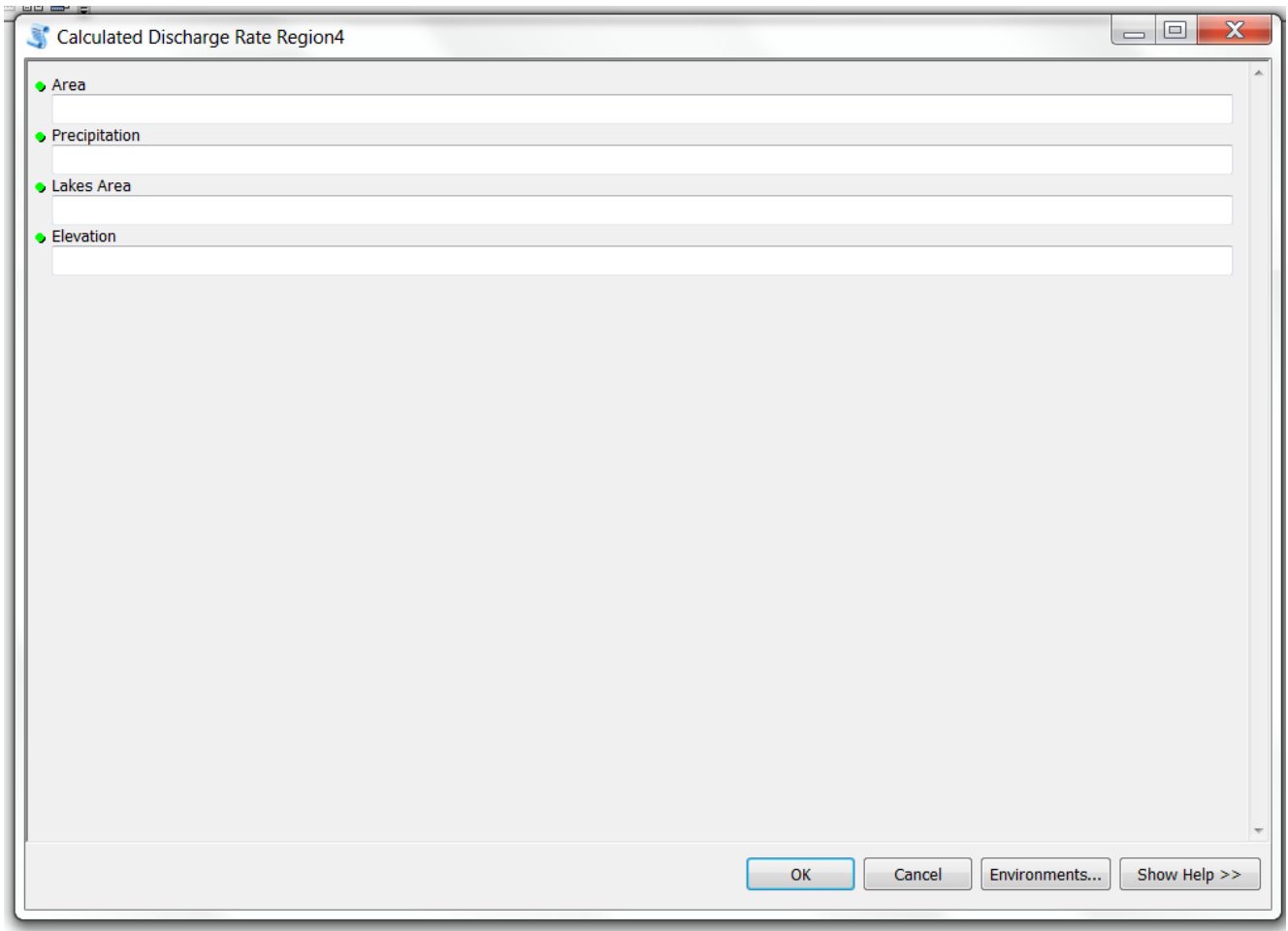

7. To update or modify the Tool parameters, open ArcMap, then ArcCatalog, navigate to the Climate Change Discharge geodatabase. Open the Discharge Calculation Toolbox. Right click the Tool Calculated Discharge for Region 3 or 4 or 5. Then right click on one of the Tool, select Properties to open the Calculate Discharge Properties dialog for any of the region. The Properties dialog which will appear as shown below. 


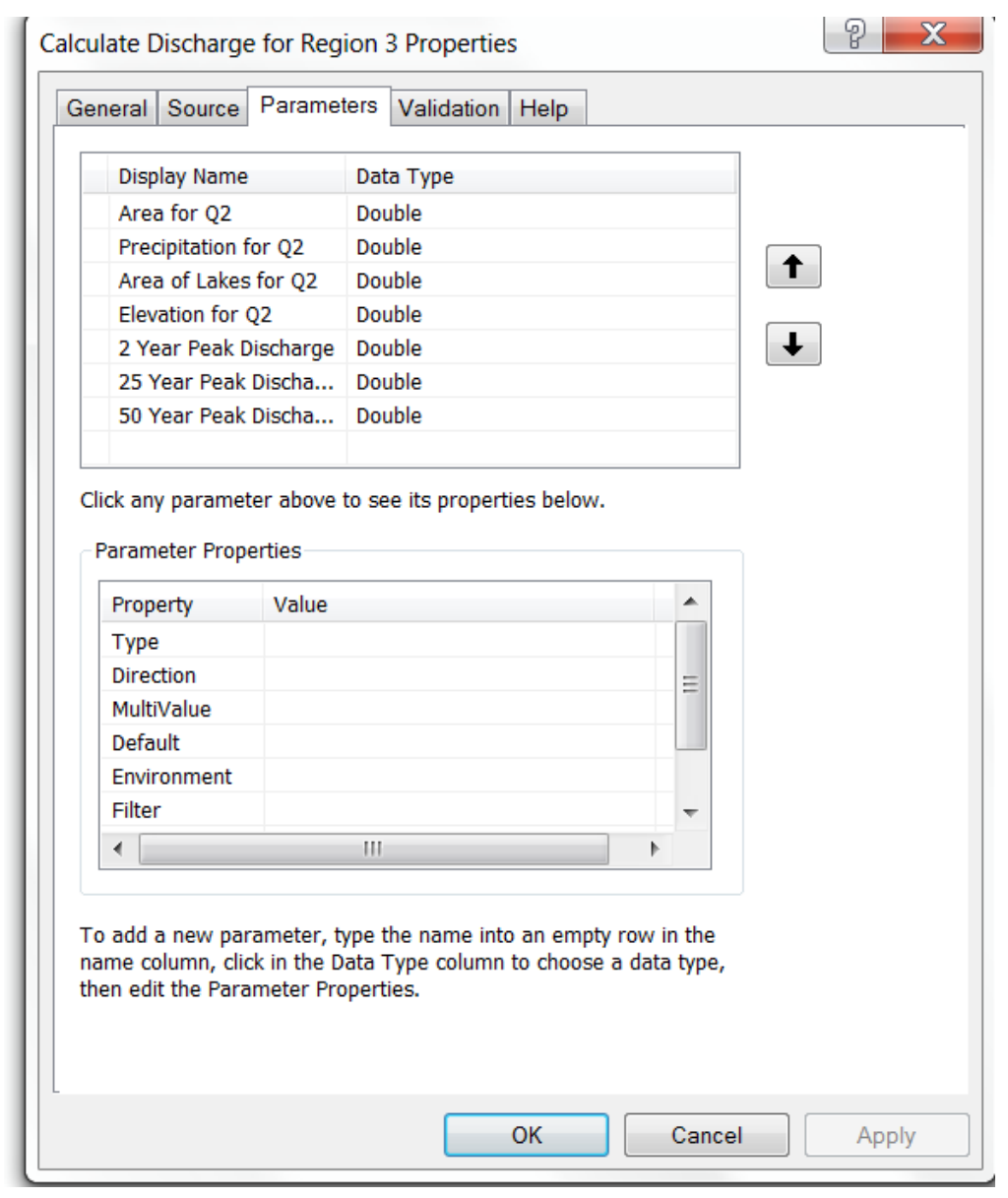

Then you should manually type the Basin Characteristics values for the region, after typing in the Basin Characteristics values, then click Source on the Calculate Discharge for Region3, then navigate to the script which will appears at once, then select one of the scripts, for example here is region 3, and then click OK, then the parameters will be updated automatically ready for use in the Tool.

8. The script and tool can always be modified to calculate peak discharge in the Yukon River Basin. 